NBER WORKING PAPER SERIES

\title{
INDEX FUNDS AND THE FUTURE OF CORPORATE GOVERNANCE: THEORY, EVIDENCE, AND POLICY
}

\author{
Lucian A. Bebchuk \\ Scott Hirst \\ Working Paper 26543 \\ http://www.nber.org/papers/w26543 \\ NATIONAL BUREAU OF ECONOMIC RESEARCH \\ 1050 Massachusetts Avenue \\ Cambridge, MA 02138 \\ December 2019
}

This Working Paper is an edited version of a study of the same title prepared for publication in the Columbia Law Review. This study, which is available at https://ssrn.com/abstract=3282794, also includes a detailed discussion of policy proposals that is omitted in this Working Paper. The study has been awarded the IRRC Institute's Investor Research Award; the European Corporate Governance Institute's Cleary Gottlieb Steen Hamilton Prize; and the VIII Jaime Fernández de Araoz Award on Corporate Finance. We have benefitted from the valuable comments of many individuals and workshop participants, as well as from the excellent work of several research assistants, all of whom are listed in the study. We gratefully acknowledge financial support from Harvard Law School and Boston University School of Law. The views expressed herein are those of the authors and do not necessarily reflect the views of the National Bureau of Economic Research.

NBER working papers are circulated for discussion and comment purposes. They have not been peer-reviewed or been subject to the review by the NBER Board of Directors that accompanies official NBER publications.

(C) 2019 by Lucian A. Bebchuk and Scott Hirst. All rights reserved. Short sections of text, not to exceed two paragraphs, may be quoted without explicit permission provided that full credit, including $(\odot$ notice, is given to the source. 
Index Funds and the Future of Corporate Governance: Theory, Evidence, and Policy Lucian A. Bebchuk and Scott Hirst

NBER Working Paper No. 26543

December 2019

JEL No. G23,G34,K22

\begin{abstract}
$\underline{\text { ABSTRACT }}$
We seek to contribute to understanding index fund stewardship by providing a comprehensive theoretical, empirical, and policy analysis of such stewardship. We put forward an agency-cost theory of the stewardship decisions that index fund managers make. Our agency-costs analysis shows that index fund managers have strong incentives to (i) underinvest in stewardship and (ii) defer excessively to the preferences and positions of corporate managers. We also undertake an empirical analysis of the full range of stewardship activities that index funds do and do not undertake. We show that the body of evidence is, on the whole, consistent with the incentive issues identified by our agency-costs framework. Finally, we explain how our analysis should reorient important ongoing debates regarding common ownership and hedge fund activism.
\end{abstract}

Lucian A. Bebchuk

Harvard Law School

1545 Massachusetts Avenue

Cambridge, MA 02138

and NBER

bebchuk@law.harvard.edu

Scott Hirst

Boston University

School of Law

Office 1402A

765 Commonwealth Avenue

Boston, MA 02215

hirst@bu.edu 


\section{TABLE OF CONTENTS}

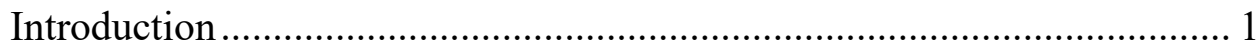

I. An Agency-Costs Theory of Index Fund Stewardship .......................... 11

A. Index Funds and Stewardship ..................................................... 11

1. Index Funds .................................................................... 11

2. Stewardship ..................................................................... 12

B. The Promise of Index Fund Stewardship ....................................... 14

C. The Value-Maximization and Agency-Costs Views ……………..... 16

D. Incentives to Underinvest in Stewardship ...................................... 19

1. The Value-Maximization Benchmark ...................................... 19

2. The Manager's Fraction of Value Increases ............................. 21

3. The Limited Effects of Competition for Funds ........................ 25

E. Incentives to Be Excessively Deferential ........................................ 28

1. The Value-Maximization Benchmark ……………………...... 28

2. Business Ties with Corporate Managers .................................. 31

3. The Private Costs of Section 13(d) Filer Status ....................... 34

4. Fears of Backlash .................................................................... 35

F. Limits on the Force of Distorting Incentives ………………............ 40

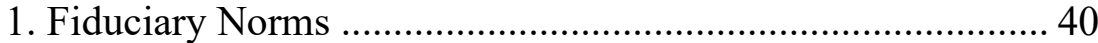

2. Reputational Constraints ....................................................... 41

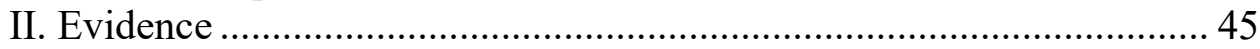

A. What the Big Three Do, and How They Do It ................................ 45

1. Stewardships Budgets and Personnel...................................... 46

(a) Current Levels of Stewardship Investment.................... 47

(b) Assessing Current Investment Levels ............................. 50

2. Private Engagements ............................................................. 55

3. Focusing on Divergences from Governance Principles ......... 59

4. Pro-Management Voting .................................................................... 61

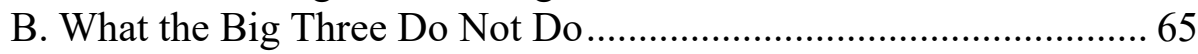

1. Monitoring Business Performance ........................................... 66

2. Influencing Director Identity.................................................... 68

3. Eliminating Divergences from Governance Principles.......... 72

4. Contributing to Corporate Governance Legal Reforms .......... 77

(a) SEC Comment Letters ................................................. 78

(b) Amicus Curiae Briefs in Precedential Litigation ............ 81

5. Involvement in Securities Litigation...................................... 84

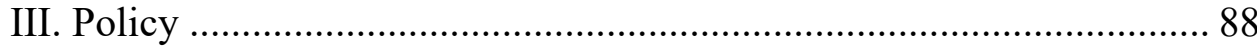

A. Implications for Key Debates........................................................ 88

1. The Debate on Common Ownership ....................................... 88

2. The Debate on Hedge Fund Activism ..................................... 91

(a) The Limits of Index Fund Stewardship.......................... 92

(b) The Limits of Hedge Fund Activism ............................... 93

B. Recognition and Reality ………………………………….......... 95

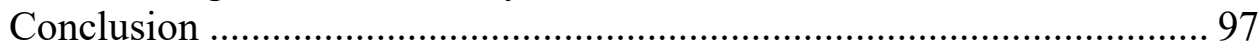

Appendix: Data Sources..................................................................... 98 


\section{INTRODUCTION}

Index funds - investment funds that mechanically track the performance of an index ${ }^{1}$ - hold an increasingly large proportion of the equity of U.S. public companies. The sector is dominated by three index fund managersBlackRock, Inc. (BlackRock), State Street Global Advisors, a division of State Street Corporation (SSGA), and the Vanguard Group (Vanguard), often referred to as the "Big Three." 2 In a recent empirical study, The Specter of the Giant Three, we document that the Big Three collectively vote about $25 \%$ of the shares in all S\&P 500 companies; ${ }^{3}$ that each holds a position of $5 \%$ or more in a large number of companies $;{ }^{4}$ and that the proportion of equities held by index funds has risen dramatically over the past two decades and can be expected to continue growing strongly. ${ }^{5}$ Furthermore, extrapolating from past trends, we estimate in that article that the average proportion of shares in S\&P 500 companies voted by the Big Three could reach as much as $40 \%$ within two decades and that the Big Three could thus evolve into what we term the "Giant Three." 6

The large and steadily growing share of corporate equities held by index funds, and especially the Big Three, has transformed ownership patterns in the U.S. public market. How index funds make stewardship decisions - how they monitor, vote in, and engage with portfolio companies - has a major

1. For a more detailed definition of index funds, see infra section I.A.1.

2. The term "Big Three" has been used in reference to Vanguard, SSGA, and BlackRock (or, prior to 2009, Barclays Global Investors, which BlackRock acquired in that year) for more than a decade. For early uses of the term in the financial press, see Rebecca Knight, Irresistible Rise of the Flexible Fund, Fin. Times (Apr. 19, 2006) (on file with the Columbia Law Review). For the academic study that seems to have been the first to introduce the term to the academic literature, see Jan Fichtner, Eelke M. Heemskerk \& Javier GarciaBernardo, Hidden Power of the Big Three? Passive Index Funds, Re-Concentration of Corporate Ownership, and New Financial Risk, 19 Bus. \& Pol. 298, 298 (2017).

3. See Lucian A. Bebchuk \& Scott Hirst, The Specter of the Giant Three, 99 B.U. L. Rev. 721, 736 (2019) [hereinafter Bebchuk \& Hirst, Specter of the Giant Three]. That article substantially expands on the evidence regarding the "bigness" of the Big Three that Fichtner, Heemskerk, and Garcia-Berardo, supra note 2, provided by, among other things, analyzing past trends, expected future trends in the growth of the Big Three, and the key factors likely to lead to their continued dominance of the industry. See Bebchuk \& Hirst, Specter of the Giant Three, supra, at 723-24. See generally Fichtner et al., supra note 2.

4. Bebchuk \& Hirst, Specter of the Giant Three, supra note 3, at 735 (presenting evidence that the Big Three held, in aggregate, 1,118 positions of $5 \%$ or more at S\&P 500 companies in 2017).

5. Id. at $732-40$.

6. Id. at $737-40$. 
impact on the governance and performance of public companies and the economy. Understanding these stewardship decisions, as well as the policies that can enhance them, is a key challenge for the field of corporate governance. This Working Paper contributes to such an understanding.

Leaders of the Big Three have repeatedly stressed the importance of responsible stewardship and their strong commitment to it. For example, then-Vanguard CEO William McNabb stated that "[w]e care deeply about governance" and that "Vanguard's vote and our voice on governance are the most important levers we have to protect our clients' investments."7 Similarly, BlackRock CEO Larry Fink stated that "our responsibility to engage and vote is more important than ever" and that "[t]he growth of indexing demands that we now take this function to a new level." ${ }^{8}$ The Chief Investment Officer of SSGA stated that "SSGA's asset stewardship program continues to be foundational to our mission."

The Big Three leaders have also stated both their willingness to devote the necessary resources to stewardship and their belief in the governance benefits that their stewardship investments produce. For example, Vanguard's McNabb has said, of governance, that "[w]e're good at it. Vanguard's Investment Stewardship program is vibrant and growing." ${ }^{10}$ Similarly, Larry Fink has stated that BlackRock "intend[s] to double the size of [its] investment stewardship team over the next three years. The growth of [BlackRock's] team will help foster even more effective engagement."11

The stewardship promise of index funds arises from their large stakes and their long-term commitment to the companies in which they invest. Their large stakes provide these funds with significant potential influence and imply that by improving the value of their portfolio companies they can help bring about significant gains for their portfolios. Furthermore, because index funds have no "exit" from their positions in portfolio companies while those companies remain in the index, they have a long-term perspective and are not tempted by short-term gains at the expense of long-term value. This long-

7. Bill McNabb, The Ultimate Long-Term Investors, Vanguard (July 5, 2017), https://global.vanguard.com/portal/site/institutional/nl/en/articles/research-andcommentary/portfolio-construction/ultimate-long-term-investors-uk [https://perma.cc/76PC-AV8P].

8. Larry Fink, 2018 Letter to CEOs: A Sense of Purpose, BlackRock (Jan. 16, 2018), https://www.blackrock.com/corporate/investor-relations/2018-larry-fink-ceo-letter (on file with the Columbia Law Review).

9. State St. Glob. Advisors, Annual Stewardship Report 2016 Year End 3 (2017), https://www.ssga.com/investment-topics/environmental-social-governance/2017/2016Annual-Stewardship-Report-Year-End.pdf [https://perma.cc/Z3BE-RMQ4] [hereinafter State St. Glob. Advisors, Annual Stewardship Report 2016].

10. McNabb, supra note 7 .

11. Fink, supra note 8. 
term perspective has been stressed by Big Three leaders ${ }^{12}$ and applauded by commentators. ${ }^{13}$ Jack Bogle, Vanguard's founder and the late elder statesman of index investing, has stated that index funds "are the ... best hope for corporate governance." 14

Will index funds deliver on this promise? Do any significant impediments stand in the way? And how do legal rules and policies affect index fund stewardship? Given the dominant and growing role that index funds play in the capital markets, these questions are of first-order importance and are the focus of this Working Paper.

In particular, the Working Paper seeks to make three contributions. The first contribution is to provide an analytical agency-cost framework for understanding the incentives of index fund managers. Our analysis demonstrates that index fund managers have strong incentives to (i) underinvest in stewardship and (ii) defer excessively to the preferences and positions of corporate managers. The incentive analysis builds on, and further develops, the analytical framework put forward in The Agency Problems of Institutional Investors, a 2017 article we coauthored with Alma Cohen. ${ }^{15}$

The second contribution is to provide the first comprehensive evidence of the full range of stewardship decisions made by index fund managers, especially the Big Three. We find that this evidence is, on the whole, consistent with the incentive issues that our analytical framework identifies. The evidence thus reinforces the questions raised by this framework.

The third contribution of our work is to explore the implications of the incentive issues of index fund managers that we identify and document. We explain below how recognition of these incentive issues should inform and influence important ongoing debates, such as those on common ownership and hedge fund activism. In the non-NBER version of this Working Paper we

12. See infra notes 38-39 and accompanying text.

13. See, e.g., Martin Lipton, Engagement-Succeeding in the New Paradigm for Corporate Governance, Harvard Law Sch. Forum on Corp. Governance \& Fin. Regulation (Jan. 23, 2018), https://corpgov.law.harvard.edu/2018/01/23/engagement-succeeding-in-thenew-paradigm-for-corporate-governance/ [https://perma.cc/NBP4-GNXG] [hereinafter Lipton, New Paradigm for Corporate Governance] ("[T]he BlackRock letter is a major step in rejecting activism and short[-]termism . . .."). For a detailed account by one of us of the appeal that "long-termism" has had to corporate law scholars and practitioners, see generally Lucian A. Bebchuk, The Myth that Insulating Boards Serves Long-Term Value, 113 Colum. L. Rev. 1637, 1646-51 (2013) [hereinafter Bebchuk, Long-Term Value].

14. Christine Benz, Bogle: Index Funds the Best Hope for Corporate Governance, Morningstar.com (Oct. 24, 2017), http://www.morningstar.com/videos/830770/bogle-indexfunds-the-best-hope-for-corporate-gove.html (on file with the Columbia Law Review).

15. See generally Lucian A. Bebchuk, Alma Cohen \& Scott Hirst, The Agency Problems of Institutional Investors, 31 J. Econ. Persp. 89 (2017) [hereinafter Bebchuk et al., Agency Problems of Institutional Investors]. 
also put forward a number of policy measures to address these incentive issues and explain why some other measures do not merit serious consideration. ${ }^{16}$

This Working Paper's analysis is organized as follows. Part I develops our agency-costs theory of index funds stewardship. We begin by discussing the nature of index funds and stewardship. We proceed to discuss the features of index funds, such as large stakes and long-term perspectives, that have given rise to high hopes for index fund stewardship. We then explain that these hopes are founded on the premise that the stewardship decisions of index fund managers are largely focused on maximizing the long-term value of their investment portfolios and that agency issues are thus not a key driver of those decisions. We contrast this "value-maximization" view with an alternative "agency-costs" view that we put forward.

In the agency-costs view, because the stewardship decisions of index funds are not made by the index funds' own beneficial investors (to whom

16. The research that is most closely related to this Working Paper consists of four current or recent works that focus on index fund stewardship but differ considerably from this Working Paper in terms of scope, methodology, approach, and normative position.

To begin, a study by John C. Coates also focuses on the increasing concentration of ownership in the hands of a small number of institutional investors. See generally John C. Coates, The Future of Corporate Governance Part I: The Problem of Twelve (Harvard Pub. Law Working Paper No. 19-07 2018), https://corpgov.law.harvard.edu/wpcontent/uploads/2019/11/John-Coates.pdf [https://perma.cc/HX8S-8ACK]. However, unlike this Working Paper, Coates's study seems to suggest that these investors will exercise too much power, rather than underinvest in stewardship and be excessively deferential to corporate managers.

In addition, studies by Jill E. Fisch, Assaf Hamdani, and Steven Davidoff Solomon, and by Edward B. Rock and Marcel Kahan, take issue with our analysis and question the magnitude of the incentive issues that we identify. But as we explain in various places below (see infra notes 57, 59, 64-65, 68-69, 86, 107, 125, 133-135, 138, 142, 161, 171-173, 178, 182-186, 191, 195, 198-199, 209, 238, 242 and accompanying text), each of these studies does not recognize some of the major issues with the stewardship that our analysis identifies. See generally Jill E. Fisch, Assaf Hamdani \& Steven Davidoff Solomon, The New Titans of Wall Street: A Theoretical Framework for Passive Investors, U. Pa. L. Rev. (forthcoming 2019), https://corpgov.law.harvard.edu/wp-content/uploads/2019/11/Jill-Fisch-AssafHamdani-Steven-Davidoff-Solomon.pdf [https://perma.cc/89XC-BHTT]; Marcel Kahan \& Edward B. Rock, Index Funds and Corporate Governance: Let Shareholders Be Shareholders (N.Y. Univ. Law \& Econ. Research Paper No. 18-39, 2019), https://corpgov.law.harvard.edu/wp-content/uploads/2019/11/Kahan-Rock.pdf [https://perma.cc/9UZF-FMEM].

Finally, a study by Dorothy Shapiro Lund puts forward a critical view of index fund stewardship, but it differs substantially from our incentive analysis, empirical investigation, and policy recommendations. See generally Dorothy Shapiro Lund, The Case Against Passive Shareholder Voting, 43 J. Corp. L. 493 (2018); see also infra notes 108 and accompanying text.

These four studies, as well as our own work, build on the substantial earlier body of literature on institutional investors discussed in note 17 , infra. 
we refer below as the "index fund investors"), but rather by their investment advisers (whom we label "index fund managers"), the incentives of index fund managers are critical. The remainder of Part I is devoted to developing the elements of the agency-costs theory. In particular, we analyze two types of incentive issues that push the stewardship decisions of index fund managers away from those that would be value-maximizing.

The first type is incentives to underinvest in stewardship. Stewardship that increases the value of portfolio companies will benefit index fund investors. Index fund managers, however, are remunerated with a very small percentage of their assets under management and thus would capture a correspondingly small fraction of such increases in value. They therefore have much more limited incentives to invest in stewardship than their beneficial investors would prefer. Furthermore, if stewardship by an index fund manager increases the value of a portfolio company, rival index funds that track the same index (and investors in those funds) will receive the benefit of the increase in value without any expenditure of their own. As a result, an interest in improving financial performance relative to rival index fund managers does not provide any incentive to invest in stewardship. In addition, we explain that competition with actively managed funds cannot be expected to address the substantial incentives to underinvest in stewardship that we identify.

The second type of incentive issues concerns incentives to be excessively deferential. When index fund managers face qualitative stewardship decisions, we show that they have incentives to be excessively deferentialrelative to what would best serve the interests of their own beneficial investors - toward the preferences and positions of the managers of portfolio companies. This is because the choice between deference to managers and nondeference not only affects the value of the index fund's portfolio but could also affect the private interests of the index fund manager.

We then identify and analyze three significant ways in which index fund managers might benefit privately from such deference. First, we show that existing or potential business relationships between index fund managers and their portfolio companies give the index fund managers incentives to adopt principles, policies, and practices that defer to corporate managers. Second, we explain that in the many companies in which the Big Three hold positions of 5\% or more of the company's stock, taking certain nondeferential actions would trigger obligations that would impose substantial additional costs on the index fund manager. Finally, and importantly, the growing power of the Big Three means that a nondeferential approach would likely encounter significant resistance from corporate managers, which would create a 
substantial risk of regulatory backlash. ${ }^{17}$

Although we focus on understanding the structural incentives that affect the stewardship decisions of index fund managers, we stress that in some cases, fiduciary norms, or a desire to do the right thing, could lead wellmeaning index fund managers to take actions that differ from those suggested by a pure incentive analysis. Furthermore, index fund managers also have incentives to be perceived as responsible stewards by their beneficial investors and by the public - and thus, to avoid actions that would make salient their underinvestment in stewardship or their deference to corporate managers. These factors could well constrain the force of the issues that we investigate. However, the structural incentive issues that we identify should be expected to have significant effects, and the evidence we present in Part II demonstrates that this is, in fact, the case.

As with any other theory regarding economic and financial behavior, the test for which of the value-maximization view or the agency-costs view is valid is the extent to which those views are consistent with and can explain the extant evidence. Part II, therefore, puts forward evidence on the stewardship decisions of the Big Three. We provide a detailed picture of what they do, how they do it, and what they do not do. We combine hand-collected data and data from various public sources to piece together this broad and detailed picture. We describe in detail the data sources used in the various empirical analyses of Part II in this Working Paper's Appendix.

The first half of Part II considers four dimensions of the stewardship that the Big Three actually undertake and how they do so. First, we examine actual stewardship investments. Our analysis provides estimates of the stewardship personnel, in terms of both workdays and dollar cost, devoted to

17. In analyzing the incentives of index funds, our work, as well as other current writings on index fund stewardship, builds on a substantial body of earlier literature on institutional investors and their potential benefits and agency costs. For well-known early works that analyze the potential benefits and limitations of institutional investors as monitors of portfolio companies, see generally Bernard S. Black, Agents Watching Agents: The Promise of Institutional Investor Voice, 39 UCLA L. Rev. 811 (1992) [hereinafter Black, Agents Watching Agents]; Bernard S. Black, Shareholder Passivity Reexamined, 89 Mich. L. Rev. 520 (1990) [hereinafter Black, Shareholder Passivity Reexamined]; John C. Coffee, Jr., Liquidity Versus Control: The Institutional Investor as Corporate Monitor, 91 Colum. L. Rev. 1277 (1991); Edward B. Rock, The Logic and (Uncertain) Significance of Institutional Shareholder Activism, 79 Geo. L.J. 445 (1991).

For recent works in this literature, see generally Ronald J. Gilson \& Jeffrey N. Gordon, The Agency Costs of Agency Capitalism: Activist Investors and the Revaluation of Governance Rights, 113 Colum. L. Rev. 863 (2013); Leo E. Strine, Jr., Can We Do Better by Ordinary Investors? A Pragmatic Reaction to the Dueling Ideological Mythologists of Corporate Law, 114 Colum. L. Rev. 449 (2014); Leo E. Strine, Jr., One Fundamental Corporate Governance Question We Face: Can Corporations Be Managed for the Long Term Unless Their Powerful Electorates Also Act and Think Long Term?, 66 Bus. Law. 1 (2010) [hereinafter Strine, One Fundamental Corporate Governance Question]. 
particular companies. Whereas supporters of index fund stewardship have focused on recent increases in the stewardship staff of the Big Three, our analysis examines personnel resources in the context of the Big Three's assets under management and the number of their portfolio companies. We show that the Big Three devote an economically negligible fraction of their fee income to stewardship and that their stewardship staffing levels enable only limited and cursory stewardship for the vast majority of their portfolio companies.

Second, we consider behind-the-scenes engagements. Supporters of index fund stewardship view private engagements by the Big Three as explaining why they refrain from using certain other stewardship tools available to shareholders. However, we show that the Big Three engage with a very small proportion of their portfolio companies, and only a small proportion of portfolio companies have more than a single engagement in any year. Furthermore, refraining from using other stewardship tools also reduces the benefits from private engagements in the small minority of cases in which such engagements do occur. The Big Three's private engagement thus cannot constitute a good substitute for the use of other stewardship tools.

Third, we describe the Big Three's focus on divergence from governance principles. Our review of the proxy voting guidelines and engagements of the Big Three demonstrates that they largely focus on the existence or absence of divergences from governance principles. But value-maximizing stewardship decisions would require also paying attention to additional company-specific information, including information about financial performance or the suitability of particular directors up for election.

Fourth, we discuss pro-management voting. We focus on votes cast by the Big Three on matters of central importance to managers, such as executive compensation and proxy contests with activist hedge funds. We show that the Big Three's votes on these matters reveal considerable deference to corporate managers. For example, the Big Three very rarely oppose corporate managers in say-on-pay votes and do so significantly less frequently than other large investment fund managers.

In the second half of Part II, we analyze in turn five dimensions of stewardship activities that the Big Three generally do not undertake. First, we examine their limited attention to business performance. Our analysis of the voting guidelines and stewardship reports of the Big Three indicates that their stewardship focuses on governance structures and processes and pays limited attention to financial underperformance. While portfolio company compliance with governance best-practices serves the interests of index fund investors, those investors would also benefit substantially from stewardship aimed at identifying, addressing, and remedying financial underperformance.

Second, we analyze how the Big Three pay limited attention to some 
important characteristics of directors and to the choice of individual directors. Index fund investors could benefit if index fund managers communicated with the boards of underperforming companies about replacing or adding certain directors. However, our examination of director nominations and Schedule 13D filings over the past decade indicates that the Big Three have refrained from such communications.

Third, we explain that the Big Three generally do not bring about improvements favored by their own governance principles. Shareholder proposals have proven to be an effective stewardship tool for bringing about governance changes at large numbers of public companies. Many of the Big Three's portfolio companies persistently do not adopt the governance bestpractices that the Big Three support. Given this inaction, and the Big Three's focus on divergences from governance principles, it would be natural for the Big Three to submit shareholder proposals to such companies aimed at addressing such inaction. But our examination of shareholder proposals over the last decade indicates that the Big Three have completely refrained from submitting such proposals.

Fourth, we analyze the frequent tendency of the Big Three to stay on the sidelines of governance reforms. Index fund investors would benefit from involvement by index fund managers in corporate governance reforms - such as supporting desirable proposed changes and opposing undesirable changes - that could materially affect the value of many portfolio companies. We therefore review the comments submitted to the SEC from 1995 through 2018 with respect to proposed rulemaking regarding corporate governance issues. We also examine amicus briefs filed from 2007 through 2018 in precedential litigation regarding corporate governance issues. We find that the Big Three have contributed very few such comments and no amicus briefs during the periods we examine, and were much less involved in such reforms than asset owners with much smaller portfolios.

Fifth, we consider the Big Three's approach of foregoing all opportunities to influence consequential securities litigation. Legal rules encourage institutional investors with "skin in the game" to take on lead plaintiff positions in securities class actions; this serves the interests of their investors by monitoring class counsel, settlement agreements and recoveries, and the terms of governance reforms incorporated in such settlements. We therefore examine the lead plaintiffs selected in the large set of significant class actions over the past decade. Although the Big Three's investors often have significant skin in the game, we find that the Big Three refrained from taking on lead plaintiff positions in any of these cases.

Taken together, this body of evidence is difficult to reconcile with the value-maximization view. On the whole, however, the documented patterns are consistent with, and can be explained by, the agency-costs view put 
forward in Part I.

Part III turns to the implications of our theory and evidence. The nonNBER version of this Working Paper includes a detailed discussion of measures for addressing the incentive issues of index fund managers. In this Working Paper we only discuss the significant implications of our analysis for two important ongoing debates. First, we consider the debate over influential but controversial claims that the rise in common ownership patterns - whereby institutional investors hold shares in many companies in the same sector - can be expected to have anticompetitive effects. We explain that our analysis indicates that these claims are unwarranted and that focusing regulatory attention on them would be counterproductive. ${ }^{18}$

With respect to the debate on hedge fund activism, our analysis also undermines claims by opponents of such activism that index fund stewardship is superior to - and should replace - hedge fund activism; rather, the incentive issues of index fund managers make the role of activist hedge funds especially important.

Part III concludes by highlighting another way in which we hope our analysis could contribute to improving index fund stewardship. Because index fund managers have an interest in having their stewardship viewed favorably by their investors and others, increased recognition of the agency issues of index fund managers could by itself induce such managers to reduce divergences from value-maximizing stewardship decisions. The issues that we identify and document can be expected to remain an important element of the corporate governance landscape. Acquiring a full understanding of these issues is thus essential for the field of corporate governance.

We have been fortunate to receive reactions and responses to our work from many academics, both in their writings and in various fora in which earlier versions of this Working Paper were presented, as well as from

18. We were invited by the FTC to discuss the implications of our work for the common ownership debate at an FTC hearing on the subject. The slides of our presentation are available in Lucian Bebchuk \& Scott Hirst, The Misguided Attack on Common Ownership (Harvard Pub. Law Working Paper No. 19-10, 2018), https://ssrn.com/abstract=3298983 (on file with the Columbia Law Review) [hereinafter Bebchuk \& Hirst, Misguided Attack on Common Ownership].

For recent attempts by a leading critic of common ownership to engage with the arguments regarding common ownership made in this Working Paper, see Einer Elhauge, The Causal Mechanisms of Horizontal Shareholding 49-58 (Aug. 2, 2019) (unpublished manuscript), https:/corpgov.law.harvard.edu/wp-content/uploads/2019/11/Elhauge-2019The-Causal-Mechanisms-of-Horizontal-Shareholding2.pdf [https://perma.cc/Q3HC-PL7W] (on file with the Columbia Law Review) [hereinafter Elhauge, The Causal Mechanisms of Horizontal Shareholding]; Einer Elhauge, How Horizontal Shareholding Harms Our Economy-And Why Antitrust Law Can Fix It 48-70 (Aug. 2, 2019) (unpublished manuscript), https://ssrn.com/abstract=3293822. 
practitioners, including index fund officers. Throughout our analysis, we attempt to engage with and respond to comments, objections, and arguments raised by such commentators. ${ }^{19}$

Before proceeding, we would like to clarify the nature of our claims. First, we do not argue that index fund stewardship produces worse outcomes for the governance of the economy's operating companies than the outcomes that would occur if the shares of the index funds were instead held by dispersed individual investors. On the contrary, we believe that, despite the issues we identify and document with index fund stewardship, the concentration of shares in the hands of index funds produces substantially better oversight than would result from the shares currently held through index funds instead being owned directly by dispersed individual investors. The evolution from the dispersion of ownership highlighted by Adolf Berle and Gardiner Means ${ }^{20}$ to the concentration of ownership among institutional investors created the potential for improved oversight. Our interest is in realizing that potential to the fullest extent possible.

Similarly, we do not claim that index fund stewardship produces worse outcomes than those that would occur if the shares currently held by index funds were instead held by actively managed mutual funds. We have shown elsewhere that the agency issues afflicting active mutual funds indicate that these issues are also substantial. ${ }^{21}$ We do not view the stewardship decisions of index funds as generally inferior to those of actively managed mutual funds, and our analysis should not be understood to provide a basis for measures to favor actively managed funds over index funds.

Instead, we focus on comparing the current stewardship decisions of index fund managers with the stewardship decisions that would best serve the interests of index funds' investors. We believe that comparing current

19. For examples of our engagement with arguments or counterarguments related to our work that have been raised by others, see, e.g., infra notes 57, 59-61, 64-65, 68-70, 86, 107108, 114-116, 118-119, 125, 133-140, 142, 144, 161-163, 171-172, 178, 182-186, 191, 195, 198-199, 204, 209, 214, 216, 221, 227-228, 238, 242 and accompanying text.

When we respond to arguments or counterarguments in working papers that have not yet been published, the relevant footnote cites the version of the working paper that was available at the time our response was written.

20. For the classic work documenting and lamenting the dispersion of ownership prior to the rise of institutional investors, see generally Adolf A. Berle \& Gardiner C. Means, The Modern Corporation and Private Property (1932).

21. For analyses of these substantial issues, see Bebchuk et al., Agency Problems of Institutional Investors, supra note 15, at 95-104; Lucian Bebchuk \& Scott Hirst, Are Active Mutual Funds More Active Owners than Index Funds?, Harvard Law Sch. Forum on Corp. Governance \& Fin. Regulation (Oct. 3, 2018), https:/corpgov.law.harvard.edu/2018/10/03/are-active-mutual-funds-more-active-ownersthan-index-funds/ [https://perma.cc/G6FQ-EDG7] [hereinafter Bebchuk \& Hirst, Active Mutual Funds]. 
stewardship decisions to this benchmark can improve our understanding of current stewardship decisions. If agency issues are indeed a first-order driver of stewardship decisions, as we argue, then the agency-costs framework can substantially contribute to a fuller understanding of stewardship decisions and policy choices in the corporate governance field.

\section{AN AgenCy-COSTS THEORY OF INDEX Fund STEWARDSHIP}

This Part develops our agency-costs theory of index fund stewardship. We start by explaining the nature of index funds and the stewardship activities they undertake in section I.A. We describe views that have been expressed about the significant promise that the nature of index funds holds for stewardship in section I.B. We explain that this is the basis for the "valuemaximization view" of index fund stewardship, and we put forward our competing "agency-costs" view in section I.C. We then develop the agencycosts view, showing how this view indicates that index fund managers will have incentives to underinvest in stewardship in section I.D, as well as incentives to be excessively deferential to managers of portfolio companies in section I.E. Finally, we consider two potential limits-arising from fiduciary norms and reputational considerations - on the force of these incentives in section I.F.

\section{A. Index Funds and Stewardship}

\section{Index Funds}

Index funds are a special type of investment fund. Investment funds pool the assets of many individuals and entities and invest those assets in diversified portfolios of securities. Actively managed investment funds buy and sell securities of companies in accordance with their views about whether those companies are under- or overvalued. ${ }^{22}$ By contrast, index funds invest in portfolios that attempt to track the performance of specified benchmark indexes, such as the S\&P 500 or the Russell $3000 .^{23}$ The term "index fund"

22. For a discussion of the approaches of actively managed funds and how they compare with index funds, see Fid. Invs., Active and Passive Funds: The Power of Both, The St. (Jan. 18, 2018), https://www.thestreet.com/story/14451001/1/active-and-passive-fundsthe-power-of-both.html [https://perma.cc/4QV5-39C2].

23. For a discussion of the strategy used by one of the largest index funds, see Vanguard, $\begin{array}{llllll}\text { Vanguard } & 500 & \text { Index } & \text { Fund } & \text { Prospectus } & 8-12\end{array}$ (2019) https://personal.vanguard.com/pub/Pdf/p040.pdf [https://perma.cc/5SXN-2NN6]. For discussions of the general workings of indexes, see Gabriel Rauterberg \& Andrew Verstein, 
encompasses both mutual funds and exchange traded funds (ETFs), or any other investment vehicle that mechanically tracks an index. ${ }^{24}$ Well-known examples of index funds include the Vanguard S\&P 500 Mutual Fund, SSGA's SPDR S\&P 500 ETF, and BlackRock's iShares Core S\&P 500 ETF. While some index funds also track indexes of debt securities, this Working Paper focuses on those that invest in equity securities.

As we analyze in detail in our recent empirical study, The Specter of the Giant Three, the index fund sector is heavily concentrated and is dominated by the Big Three. ${ }^{25}$ In that study we explain that such concentration is to be expected and should be expected to persist. ${ }^{26}$ The dominant incumbents have significant structural advantages that derive from the economies of scale of operating index funds; the funds' branding; and - in the case of ETFs - the liquidity benefits for funds with large asset bases. In addition, there are no significant opportunities for new entrants to attract business from the incumbents by introducing new products that would be difficult for the incumbents to imitate. ${ }^{27}$

\section{Stewardship}

In the literature on institutional investors, stewardship refers to the actions that investment managers can take in order to enhance the value of the companies that they invest in on behalf of their own beneficial investors. ${ }^{28}$

Index Theory: The Law, Promise and Failure of Financial Indices, 30 Yale J. on Reg. 1, 623 (2013), and of indexes underlying index funds specifically, see Scott Hirst \& Kobi Kastiel, Corporate Governance by Index Exclusion Symposium, 99 B.U. L. Rev. 1229, 1231-32 (2019); Adriana Z. Robertson, Passive in Name Only: Delegated Management and Index Investing, Yale J. on Reg. 795, 799-809 (2019).

24. For a discussion of the rules governing mutual funds and ETFs, see Lois Yurow, Timothy W. Levin, W. John McGuire \& James M. Storey, Mutual Funds Regulation and Compliance Handbook $\S 4: 1$ (2017); William A. Birdthistle, The Fortunes and Foibles of Exchange-Traded Funds: A Positive Market Response to the Problems of Mutual Funds, 33 Del. J. Corp. L. 69, 76-86 (2008).

25. See Bebchuk \& Hirst, Specter of the Giant Three, supra note 3, at 727-31. For example, that study documents that forty-five of the fifty largest ETFs (by assets under management) are managed by BlackRock, Vanguard, or SSGA. Id. at 730-31.

26. Id. at $729-31$.

27. For an analysis of these structural advantages, see id.

28. See, e.g., BlackRock, The Investment Stewardship Ecosystem 6 https:/www.blackrock.com/corporate/literature/whitepaper/viewpoint-investment-

stewardship-ecosystem-july-2018.pdf [https://perma.cc/G4KA-QLA9] [hereinafter BlackRock, Stewardship Ecosystem] (defining stewardship as "engagement with public companies to promote corporate governance practices that are consistent with encouraging long-term value creation for shareholders in the company" and stating that "[p]roxy voting is often associated with investment stewardship, however, voting is not the only form that stewardship can take"). 
Most advanced economies now have stewardship principles or codes that seek to provide guidance to institutional investors. ${ }^{29}$ We focus here on stewardship that aims to enhance the value of the company. ${ }^{30}$ Stewardship by institutional investors, including by the index funds that are the focus of this Working Paper, includes three components: monitoring, voting, and engagement.

Monitoring involves evaluating the operations, performance, practices, and compensation and governance decisions of portfolio companies. It provides the informational basis for the voting and engagement decisions of index funds.

Voting at shareholder meetings is a key function of index fund managers and other shareholders. Shareholders vote on the election of directors to manage the corporation; charter and bylaw amendments; mergers, dissolutions, and other fundamental changes in the corporation; and advisory votes on executive compensation and shareholder proposals. ${ }^{31}$ Index funds (along with other investment funds) generally vote on these matters, and index fund managers determine how their funds vote. ${ }^{32}$

Engagement refers to interactions between index fund managers and their portfolio companies in ways other than voting-for example, by submitting shareholder proposals, nominating directors, and undertaking

29. For recent efforts in the United Kingdom and the United States, see generally Fin. Reporting Council, UK Stewardship Code (2012), https://www.frc.org.uk/getattachment/d67933f9-ca38-4233-b603-3d24b2f62c5f/UK-

Stewardship-Code-(September-2012).pdf (on file with the Columbia Law Review); About the Investor Stewardship Group and the Framework for U.S. Stewardship and Governance, Institutional Stewardship Grp., https://isgframework.org/ [https://perma.cc/SFP8-5U4P] (last visited Aug. 5, 2019).

30. Some institutional investors, such as socially responsible investment funds, might have goals other than enhancing value. We do not discuss this type of stewardship in this Working Paper. For a discussion of such stewardship by one of us, see generally Scott Hirst, Social Responsibility Resolutions, 43 J. Corp. L. 217, 222-34 (2018).

We also note that some investors in indexed products seek to screen out some companies from the portfolio in which they invest, and index fund managers therefore also manage portfolios that follow such exclusions. Investor demands for exclusion of certain investments, and the impact they might have on corporate behavior, are outside the scope of this Working Paper, as we focus on the stewardship decisions of index fund managers with respect to those companies that are included in managed portfolios. For an article discussing index exclusions, see generally Hirst \& Kastiel, supra note 23.

31. For a well-known article on shareholder voting, see generally Frank H. Easterbrook \& Daniel R. Fischel, Voting in Corporate Law, 26 J.L. \& Econ. 395 (1983).

32. For the Department of Labor's interpretation of investment manager voting requirements, see Dep't of Labor, Interpretive Bulletin Relating to the Exercise of Shareholder Rights and Written Statements of Investment Policy, Including Proxy Voting Policies or Guidelines, 29 C.F.R. § 2509.2601-01 (2019). 
proxy contests. Among other forms of engagement, index fund managers (and other shareholders) can communicate publicly or privately with managers and directors of their portfolio companies. These communications can be proactive and initiated by the investor, or reactive, as when an investor responds to contact from a portfolio company or other investors.

In the remainder of Part I, we will distinguish between two types of decisions that index fund managers must make regarding stewardship activities. One type of decision is quantitative: determining the level of investment that the index fund manager will make on stewardship activities. The other type of decision is qualitative: determining the level of deference that the index fund manager will give to the corporate managers that lead particular portfolio companies. In sections I.D and I.E, below, we discuss the respective value-enhancing benchmarks for each of these two types of decisions.

\section{B. The Promise of Index Fund Stewardship}

The leaders of the Big Three, and supporters of index fund stewardship, have expressed the view that such stewardship can be expected to produce significant benefits. ${ }^{33}$ As we explain in this section, this view seems to be based on three characteristics of index funds in general, and the Big Three in particular: (i) their large and growing stakes in publicly traded companies; (ii) their inability to exit poorly-performing companies, rather than trying to fix their governance issues; and (iii) their long-term focus. Below we discuss each of these three factors in turn.

To begin, the large and growing stakes held by each of the Big Three give them significant influence over the outcomes of corporate votes. This influence leads, in turn, to their substantial influence over the decisions of corporate managers, even before matters come to a vote.

A priori, we would expect the large stakes that each of the Big Three holds in their portfolio companies to motivate them to maximize the value of those companies. A standard "free-rider" problem in corporations is that the

33. For example, Vanguard has stated that "good governance and effective stewardship can add value ... . Good governance is good for investors." Glenn Booraem, What We Do. How We Do It. Why It Matters. 2 (2019), https://about.vanguard.com/investmentstewardship/perspectives-and-commentary/what_how_why.pdf [https://perma.cc/83AAAZHM] [hereinafter Booraem, What We Do]. SSGA's CEO has stated that "[o]ur focus in recent years has been on good governance." Letter from Cyrus Taraporevala, CEO, SSGA, to Portfolio Company Board Members 1 (Jan. 15, 2019), https://www.ssga.com/investmenttopics/environmental-social-governance/2019/01/2019\%20Proxy\%20LetterAligning\%20Corporate\%20Culture\%20with\%20Long-Term\%20Strategy.pdf [https://perma.cc/2UHZ-JTKN] [hereinafter Letter from Cyrus Taraporevala]. 
benefits of improving corporate value are shared with other investors. ${ }^{34} \mathrm{~A}$ very large investor like a Big Three index fund family will capture a larger fraction of these benefits than a smaller investor. For instance, an index fund family that holds $5 \%$ of the shares of a particular company will capture ten times as much from an increase in the value of that company than a smaller investment fund family holding $0.5 \%$ of the same company. ${ }^{35}$ As a result, the interests of the investors of the large index fund manager might call for a larger investment in stewardship than the interests of the investors of the smaller investment fund family.

The second relevant characteristic of index funds is the lack of an exit option. If other types of investors are dissatisfied with the performance of their portfolio companies they can take the "Wall Street walk" and sell their shares. ${ }^{36}$ By contrast, because index funds replicate their benchmark index, they are unable to exit from a particular portfolio company while it remains in the index. Indeed, SSGA's CEO has referred to SSGA as representing "essentially permanent capital," "37 and Vanguard's then-CEO McNabb has described Vanguard's index funds as being "permanent shareholders." 38 The lack of an exit option increases the relative importance of stewardship and engagement. BlackRock CEO Fink has stated that "BlackRock cannot express its disapproval by selling the company's securities as long as that company remains in the relevant index. As a result, our responsibility to engage and vote is more important than ever." 39

A third characteristic of index funds that is potentially attractive to supporters of their stewardship is their long-term investment horizon. Both

34. For a classic and influential discussion of the free-rider issue, see Robert Charles Clark, Corporate Law 389-400 (1986).

35. For an explanation of fund families, see infra note 50 and accompanying text.

36. For an excellent review of the financial economics literature on exit, see Alex Edmans \& Clifford G. Holderness, Blockholders: A Survey of Theory and Evidence, in Handbook of the Economics of Corporate Governance 541, 574-82 (Benjamin E. Hermalin \& Michael S. Weisbach eds., 2017); Alex Edmans, Blockholders and Corporate Governance, 2014 Ann. Rev. Fin. Econ. 23, 28-32. As Edmans has highlighted, exit decisions by other investors can affect corporate behavior. For surveys of his and others' work on exit decisions and governance, see id. at 26-44.

37. Cyrus Taraporevala, Index Funds Must Be Activists to Serve Investors, Fin. Times, (July 24, 2018), https://www.ft.com/content/4e4c119a-8c25-11e8-affd-da9960227309 (on file with the Columbia Law Review). Supporters of index fund stewardship have also focused on the lack of exit options for index funds. See, e.g., Fisch et al., supra note 16 (manuscript at 43) ("Passive investors must ... rel[y] on voice, rather than exit.").

38. F. William McNabb III, Getting to Know You: The Case for Significant Shareholder Engagement, Harvard Law Sch. Forum on Corp. Governance \& Fin. Regulation (June 24, 2015), https://corpgov.law.harvard.edu/2015/06/24/getting-to-know-you-the-case-forsignificant-shareholder-engagement/ [https://perma.cc/5QZL-VZCY].

39. Fink, supra note 8 . 
BlackRock and Vanguard have referred to themselves as "the ultimate longterm investors." 40 There is significant debate in the literature about the extent to which the existence of investors with short-term horizons has adverse effects on corporate governance. ${ }^{41}$ The long-term investment horizons of index funds obviate any such questions and therefore makes stewardship by index fund managers especially attractive to commentators who raise issues regarding short-termism. ${ }^{42}$ Consistent with this view, SSGA states that they "actively engage with [their] portfolio companies to promote the long-term value of [their clients'] investments." 43 Vanguard states that it is "the ultimate long-term investor," 44 and that its "emphasis on investment outcomes over the long term is unwavering." 45

Can the large stakes of index funds, their lack of exit options, and their long-term perspective combine to enable them to deliver on the promise they hold for corporate governance? In subsequent parts of this Working Paper we analyze the impediments to such delivery.

\section{The Value-Maximization and Agency-Costs Views}

In highlighting the above characteristics, index fund leaders and supporters of index fund stewardship implicitly assume that the managers of index fund families largely act to maximize the long-term value of the portfolios they manage; ${ }^{46}$ we therefore refer to this view as the "value-

40. Booraem, What We Do, supra note 33, at 6 ("Vanguard is the ultimate long-term investor."); Fink, supra note 8 ("[I]ndex investors are the ultimate long-term investors.").

41. For an exchange on this subject between one of us and Delaware Supreme Court Chief Justice Leo Strine, Jr., see generally Bebchuk, Long-Term Value, supra note 13, and Strine, One Fundamental Corporate Governance Question, supra note 17.

42. For instance, Martin Lipton has stressed that "BlackRock, State Street and Vanguard have continued to express support for sustainable long-term investment." Martin Lipton, Activism: The State of Play, Harvard Law Sch. Forum on Corp. Governance \& Fin. Regulation (Sept. 23, 2017), https://corpgov.law.harvard.edu/2017/09/23/activism-the-stateof-play/ [https://perma.cc/4KEA-JUFB] [hereinafter Lipton, State of Play]. For a detailed review by one of us of the short-termism questions expressed by many academics, practitioners, and public officials, see Bebchuk, Long-Term Value, supra note 13, at 165886.

43. State St. Glob. Advisors, Annual Stewardship Report 2016, supra note 9, at 3.

44. Booraem, What We Do, supra note 33, at 6.

45. Vanguard, Investment Stewardship 2018 Annual Report 3 (2018), https://about.vanguard.com/investment-stewardship/annual-report.pdf [https://perma.cc/GFV4-RDD4] [hereinafter Vanguard, Annual Stewardship Report 2017$2018]$.

46. For communications by Big Three officers making these premises explicit, see, for example, BlackRock, BlackRock Investment Stewardship Engagement Priorities for 2019, at 2 (2019), https://www.blackrock.com/corporate/literature/publication/blk-stewardship- 
maximization" view of index fund stewardship. This view attaches limited significance to potential agency issues within index funds and does not view such issues as first-order drivers of stewardship decisions.

Below we put forward an alternative to the value-maximization view. Because stewardship decisions are made by investment managers, we believe that it is critical to assess their incentives regarding stewardship. An examination of these incentives and the evidence we put forward regarding investment managers' stewardship decisions, indicates that agency issues are a first-order driver of the stewardship decisions of index fund managers, and that these decisions cannot be properly understood without recognizing these agency issues.

Before examining the incentives of index fund managers, it is useful to recognize several characteristics of index fund managers that play an important role in our theory. To begin, index funds are generally structured as corporations or statutory trusts, with their own directors or trustees. But these directors or trustees have a very limited set of responsibilities, and the key decisions in operating index funds are made by the funds' investment advisors. ${ }^{47}$ Throughout this Working Paper the term "index fund managers" refers to those investment advisors, including BlackRock, Vanguard, and SSGA, that make key decisions for index funds. ${ }^{48}$ It is the incentives and

priorities-final.pdf [https://perma.cc/XW7G-7NLP] [hereinafter BlackRock, Stewardship Engagement Priorities 2019] ("BlackRock, as a fiduciary investor, undertakes all investment stewardship engagements and proxy voting with the goal of protecting and enhancing the long-term value of our clients' assets."); BlackRock, Stewardship Ecosystem, supra note 28, at 6 ("BlackRock's approach to investment stewardship is driven by our role as a fiduciary to our clients, the asset owners."); Booraem, What We Do, supra note 33, at 1, 6 ("[Vanguard has] grown only more steadfast in our sense of responsibility for our clients and our safeguarding of their interests .... We act in the best interest of Vanguard fund investors.").

47. For a detailed discussion of the governance of index funds, see Eric D. Roiter, Disentangling Mutual Fund Governance from Corporate Governance, 6 Harv. Bus. L. Rev. 1, 13-24 (2016).

48. BlackRock is a public company, and SSGA is an operating unit of a public company, so it is reasonable to assume that they both seek to maximize their profits and, in turn, the value of their index fund management business. In contrast, Vanguard is owned by its investment funds. For an explanation of Vanguard's ownership structure, see Why Ownership Matters at Vanguard, Vanguard, https://about.vanguard.com/what-sets-vanguardapart/why-ownership-matters/ [https://perma.cc/XS5E-TJDN] (last visited Aug. 30, 2019). Vanguard appears to operate by constraining its fees to the point that leaves its business with no profit. This raises the interesting question of which objectives the business leaders of Vanguard maximize. One plausible assumption, which is consistent with our incentive analysis in this Part, is that these business leaders aim to be successful by expanding the scale of their business. For Vanguard's own view of how its ownership structure affects its incentives, see Booraem, What We Do, supra note 33, at 7 ("This unique structure aligns our interests with those of our investors .... It's their money."). 
decisions of index fund managers that are our focus in this Working Paper. ${ }^{49}$

The economies of scale in investment management mean that most investment managers now manage dozens or hundreds of investment funds, often referred to collectively as "fund complexes" or "fund families." While some investment fund families consist largely of actively managed funds, each of the Big Three fund families consists predominantly of index funds. ${ }^{50}$

For the Big Three, as with many other investment managers, the key stewardship decisions are centralized in a dedicated stewardship department of the index fund manager. ${ }^{51}$ An important component of the stewardship decisionmaking of the index fund manager relates to the level of resources it devotes to this department, as well as to the qualitative decisions that the department makes.

The remainder of this Part develops an analytical framework for understanding the incentives of index fund managers. Sections I.D and I.E below analyze how the fact that investment managers manage other people's money incentivizes them to diverge from this benchmark in two important ways. In particular, section I.D examines the index fund managers' incentives to underinvest in stewardship compared to the value-maximizing level. Section I.E focuses on the qualitative stewardship decision of how deferential to be toward corporate managers, and shows that index fund managers have incentives to be excessively deferential. Finally, section I.F discusses some constraints that limit the force of the distorted incentives that we identify.

49. For early writing stressing the need to consider the incentives of institutional investors, see Black, Shareholder Passivity Reexamined, supra note 17, at 595-96; Jill E. Fisch, Relationship Investing: Will It Happen? Will It Work?, 55 Ohio St. L.J. 1009, 103847 (1994); Rock, supra note 17, at 469-78.

50. As of June 2017, the proportion of assets invested in index funds was $79 \%$ for SSGA, $74 \%$ for Vanguard, and $66 \%$ for BlackRock. In contrast, only $14 \%$ of Fidelity's assets under management were invested in index funds. Hortense Bioy, Alex Bryan, Jackie Choy, Jose Garcia-Zarate \& Ben Johnson, Passive Fund Providers Take an Active Approach to $\begin{array}{llll}\text { Investment } & \text { Stewardship } & 4 & \text { (2017), }\end{array}$ prd.morningstar.com/content/dam/marketing/shared/pdfs/Research/Morningstar-PassiveActive-Stewardship.pdf [https://perma.cc/RQY2-F68E].

51. See, e.g., Booraem, What We Do, supra note 33, at 3 ("Historically, proxy voting on behalf of all of Vanguard's index and actively-managed funds has been administered centrally by Vanguard's Investment Stewardship team."); State St. Glob. Advisors, Stewardship Report 2018-2019, at 22 (2019), https://www.ssga.com/investmenttopics/environmental-social-governance/2019/09/annual-asset-stewardship-report-2018.pdf [https://perma.cc/N37N-QM9D] [hereinafter State St. Glob. Advisors, Annual Stewardship Report 2018] ("All voting and engagement activities are centralized within our Stewardship Team ....”); Fichtner et al., supra note 2, at 316-17 (showing empirically that the centralized stewardship departments of each of the Big Three produce highly consistent voting within fund families). 


\section{Incentives to Underinvest in Stewardship}

In this section we consider index fund managers' incentives with respect to the first dimension of stewardship decisions we identified in section I.A, the level of investment in stewardship activities. Section I.D.1 discusses the value-maximization benchmark - that is, the investment level that would best serve the interests of index fund investors. Section I.D. 2 discusses the investment-level decisions that index fund managers will make, assuming, for simplicity, that both the fee levels that index fund managers charge and the size of their investment portfolio are fixed. Section I.D.3 relaxes this assumption and considers how the possibility of a competitive benefit from stewardship could affect index fund manager incentives.

\section{The Value-Maximization Benchmark}

To assess the investment-level decisions of index fund managers, it is first necessary to define a benchmark for desirable stewardship decisions. The benchmark for value-enhancing stewardship decisions made by the investment managers are those that would be best for investors in the index funds. These are also the stewardship decisions that would be made if there were no agency separation between the index fund manager and the investors in the index fund - that is, in a "sole-owner" benchmark, in which the index fund's portfolio had a sole owner that managed the portfolio and was expected to make all of the stewardship decisions that would enhance its value.

Investment in a certain stewardship activity will be desirable to the extent, and only to the extent, that the marginal gain to the index fund's portfolio, on an expected value basis, will exceed the marginal cost of this investment. To formalize our analysis, we refer to the investment stewardship activity as the "stewardship investment," denoted by $I_{S}$. We will refer to the "expected gain from stewardship investment" to the portfolio of the index fund as $G\left(I_{S}\right)$. As is standard in economics, it is reasonable to assume that the marginal expected gain from additional investment is positive, but that this marginal gain declines as the level of investment rises. ${ }^{52}$

52. This is an application of the so-called "law of diminishing returns." For an examination of the history of the law of diminishing returns, see generally Stanley L. Brue, Retrospectives: The Law of Diminishing Returns, 7 J. Econ. Persp. 185 (1993). For examples of the use of the standard assumption in a standard textbook, see, N. Gregory Mankiw, Principles of Economics 525 (8th ed. 2017) ("The traditional view of the production process is that capital is subject to diminishing returns: As the stock of capital rises, the extra output produced from an additional unit of capital falls."). Applying the standard premise to our analysis, the formal assumption is that $G^{\prime}\left(I_{S}\right)$ (the first derivative of $G$ with respect to $I_{S}$ ) is positive, and that $G^{\prime \prime}\left(I_{S}\right)$ (the second derivative of $G$ with respect to $I_{S}$ ) is negative. 
From the perspective of the beneficial investors in an index fund, it will be desirable for the investment fund manager to continue increasing the level of investment $I_{S}$ as long as the marginal gain from each additional dollar of investment exceeds one dollar. Thus, it will be desirable to set the level of investment that is optimal for the beneficial investors, which we denote as $I_{S}{ }^{*}$. This is the level that occurs where $G^{\prime}\left(I_{S}{ }^{*}\right)$ is equal to 1 , that is, the marginal gain from an extra dollar of stewardship investment is equal to one dollar.

We wish to note two comments regarding this benchmark of the value maximizing level $I_{S}{ }^{*}$. First, the level that is optimal from the perspective of the index fund's beneficial investors, $I_{S}{ }^{*}$, is generally lower than the socially desirable stewardship investment level. That is because the gain produced by this stewardship for the index fund's portfolio is only a fraction of the increase in the value of the portfolio company. Because the index fund investors will not fully capture the gains to the portfolio company from the investment in stewardship, the optimal level of investment from the perspective of these investors would not take into account the positive externalities that the index fund stewardship would confer on other shareholders in the portfolio company. This divergence reflects the free-rider issue among investors that has long been recognized. ${ }^{53}$

Second, although the level of the stewardship investments that would be best from the perspective of the index fund's beneficial investors would not take into account benefits to other shareholders, the stewardship investment level could be substantial for index fund managers that have very large amounts of assets under management. For instance, if an index fund manager holds a stake of $\$ 1$ billion in a portfolio company and stewardship is expected to increase the value of the company by $0.1 \%$, it would be desirable to make an additional marginal investment of up to $\$ 1$ million in such stewardship. Even if the expected gain were as little as $0.01 \%$, it would justify an additional marginal investment in stewardship as long as that investment is below $\$ 100,000$.

Each of the Big Three has positions of $\$ 1$ billion or more in numerous companies. ${ }^{54}$ As of June 30, 2019, the Big Three collectively held more than 1,000 positions of $\$ 1$ billion or more, with BlackRock holding more than 400

53. See supra note 34 .

54. The median value of positions in S\&P 500 companies for BlackRock, Vanguard, and SSGA as of June 30, 2019 were \$1.6 billion, \$2.0 billion, and \$1.0 billion, respectively. Calculations are based on ownership data from FactSet Res. Sys., Ownership Database (last visited Oct. 3, 2019) and S\&P 500 constituency data from Compustat (last visited Oct. 3, 2019). 
such positions, Vanguard more than 500, and SSGA more than $250 .{ }^{55}$ From the perspective of a beneficial investor in a Big Three index fund, substantial investments in stewardship are therefore likely to be value enhancing in many cases.

\section{The Manager's Fraction of Value Increases}

Let us first assume that index fund managers take their assets under management and fee structures as given. This simplifying assumption highlights a key driver of the gap between the interests of index fund managers and those of beneficial investors in their funds. Index fund managers generally cover the cost of investments in stewardship from the stream of fee income that they receive over time from investment funds. As we explain below, however, the increase in the present value of fee revenues they can expect to receive is only a tiny fraction of the expected value increase from stewardship.

Given our assumption that stewardship does not affect the level of assets under management, the private benefits to index fund managers from stewardship only come from the increased fees that would result from an increase in the value of the index funds' given assets. Under existing arrangements, index fund managers charge their investors fees that are usually specified as a very small fixed percentage of assets under management. ${ }^{56}$ As a result, the index fund manager will be able to capture a gain that represents only a small fraction of the gain produced by the stewardship.

To be sure, if stewardship produces a sustainable increase in value, the index fund manager will benefit from a small increase in fees in future years as well as the current year, but the present value of the stream of small fee increases over time will still represent only a small fraction of the value increase produced by the stewardship. To illustrate, consider an index fund manager that has a $\$ 1$ billion position; that expects a certain stewardship

55. Specifically, the numbers of $\$ 1$ billion positions for each of the Big Three as of June 30, 2019 were 423 for BlackRock, 515 for Vanguard, and 257 for SSGA. These calculations are based on ownership data from FactSet Res. Sys., Ownership Database (last visited Oct. 3, 2019).

56. Amounts that investment managers charge to investors also include certain expenses, such as legal expenses and expenses related to custody of portfolio assets. See SEC, Form N-1A, https://www.sec.gov/files/formn-1a.pdf [https://perma.cc/K3MB-JNLB] (last visited Aug. 30, 2019). These are all included in the annual fund operating expenses that investment funds are required to disclose, see 17 C.F.R. $\$ 274.11$ A (2019), which are calculated as a percentage of investment, and commonly referred to as the "expense ratio." When we refer to fees charged to investors we include all amounts included in the expense ratio. 
investment to produce an expected (sustainable) value increase of $0.1 \%$ (that is, $\$ 1$ million); and that charges and expects to continue to charge an annual fee of $0.1 \%$ of the value of assets under management. In this case, the manager would expect to capture increased fees with an expected value of $\$ 1,000(0.1 \% \times \$ 1$ million $)$ each year. Assuming this stream is expected to continue indefinitely, and that the discount rate is $10 \%$, the present value of an extra $\$ 1,000$ a year is $\$ 10,000$, which is equal to $1 \%$ of the expected value increase of $\$ 1$ million produced by the stewardship.

Formally, let us use the term "fractional fee," which we will denote as $\theta$, for the fraction of any gain from stewardship that the index fund manager will be able to capture. ${ }^{57}$ Given the fractional fee $\theta$, if a stewardship investment of $I_{S}$ is expected to produce an increase of $G\left(I_{S}\right)$ in the value of the index fund manager's position, then the index fund manager would be able to capture for itself only $\theta \times G\left(I_{S}\right)$ of the expected gain to the portfolio.

From the perspective of the index fund manager, it will be desirable to increase the level of investment in stewardship only up to the point after which a further increase would produce a private marginal gain to the index fund manager that no longer exceeds the private cost to the manager from such an increase. The private gain to the index fund manager from a marginal $\$ 1$ increase in stewardship investment is equal to $\theta \times G^{\prime}\left(I_{s}\right)$ (as $G^{\prime}\left(I_{s}\right)$, the derivative of $G$ with respect to $I_{s}$, is the marginal increase in the value of the index fund's position as a result of the marginal $\$ 1$ increase in stewardship investment). Thus, the level of stewardship investment that will be desirable from the perspective of the index fund manager, which we denote as $I_{S}{ }^{* *}$, will occur when the marginal private gain of $\theta \times G^{\prime}\left(I_{S}^{* *}\right)$ equal to the $\$ 1$ cost of an additional dollar of stewardship investment.

As a consequence, the level of investment that will be desirable from the private perspective of the index fund manager, $I_{S}{ }^{* *}$, will generally be lower than the level of investment that is desirable for the beneficial investors in the index fund, $I_{S}{ }^{*}$. This is because the investment fund manager will capture

57. Formally, denoting by $\alpha$ the (small) percentage of each dollar under management that the index fund manager can expected to receive as fees each year, and denoting by $r$ is the relevant discount rate, the fractional fee $\theta$ is equal to the sum of $\alpha \times 1+\alpha \times 1 /(1+r)+$ $\alpha \times 1 /(1+r)^{2}+\alpha \times 1 /(1+r)^{2} \ldots$ Kahan and Rock argue that we understate the incentives of index fund managers because we "assum[e] annual fees are earned for only one year." Kahan \& Rock, supra note 16, at 15 n.59. However, as stated above and in earlier versions of this Working Paper, we use the present value of the stream of fees. This definition of the fractional fee as the fraction of value represented by the present value of the increases in the stream of fees was already included as an element in the analytical framework introduced in our work with Alma Cohen on which this Working Paper builds. See Bebchuk et al., Agency Problems of Institutional Investors, supra note 15, at 97 (defining the fractional fee as the "fraction of the increase in the value of a portfolio company that an investment fund will be able to capture, in present value terms, from additional fees" (emphasis added)). 
only a fraction, $\theta$, of the marginal gain to the beneficial investors in the index fund. For the index fund manager's private marginal gain to be equal to one, the marginal gain in the value of the portfolio will not be one, but will be much higher, $1 / \theta$. When the potential investment in stewardship is between $I_{S}{ }^{* *}$ and $I_{S}{ }^{*}$, the marginal gain to the index fund portfolio from an additional $\$ 1$ investment will be more than $\$ 1$. Such additional stewardship investment would therefore be desirable from the perspective of the index fund's beneficial investors. But throughout this range, additional stewardship investment will not be in the interest of the index fund manager.

What is the practical significance of this issue? In assessing this critical question, it is important to recognize the very small quantum of the fees that index funds charge. The average expense ratios for the Big Three-the combined fees and expenses that they receive for their services as a percentage of assets under management - are $0.30 \%, 0.09 \%$, and $0.17 \%$ for BlackRock, Vanguard, and SSGA, respectively, ${ }^{58}$ and the fee percentages are even lower as these figures also include expenses. The tiny fee percentages charged by index funds are attractive to investors and have driven their phenomenal growth. As the analysis above has demonstrated, however, the tiny fraction of expected gains captured by index fund managers through these fees gives them a correspondingly tiny incentive to make additional marginal investments in stewardship.

Recall the example of an index fund with a $\$ 1$ billion position in a company for which stewardship would generate a modest gain of $0.1 \%$. Even though the level of the expected gain is small, given the size of its position, it would be value maximizing for the index fund to increase its marginal investment in stewardship up to $\$ 1$ million to achieve such a gain. That is, the index fund should employ a team of professionals that would dedicate significant time to stewardship at that particular company. But if the index fund's fractional fee, $\theta$, is $1 \%$, the index fund manager's interests would not be served by any additional marginal increase in stewardship investments exceeding $\$ 10,000$.

More generally, the highest level of additional marginal stewardship investment that would serve the private interest of the index fund manager in that case is $1 \%$ of the level at which additional marginal stewardship investment would result in marginal stewardship gains for index fund investors. Thus, the index fund manager would not have an incentive to employ a team of professionals to spend significant time on stewardship for that company, even though such stewardship would result in marginal gains to the index fund portfolio. The $\$ 10,000$ additional marginal investment in stewardship that would serve the index fund manager's interests could fund Review).

58. Morningstar, Inc., U.S. Fund Fee Study 12 (2019) (on file with the Columbia Law 
only a limited fraction of a single person's annual salary, and hence, their time.

Consider now a situation in which the expected gain is a mere $0.01 \%$. In this case, it would be in the interests of the beneficial investors in the index fund to make additional marginal stewardship investments of up to $\$ 100,000$ to bring about this gain. But if the index fund manager's fractional fee is again $1 \%$, the index fund manager would have no incentive to make additional marginal stewardship investments of more than $\$ 1,000$.

We wish to stress that even though $I_{S} * *$, the investment level that best serves the private interests of the index fund manager, is lower than the level that is desirable for the beneficial investors, $I_{S}{ }^{*}$, the level of investment that would serve the interest of the index fund manager might well be significant in many cases. This is the case even though the fractional share, $\theta$, is small, because the gain for the portfolio, $G\left(I_{S}\right)$, will be very large for an index fund that has very large amounts of assets under management — as do each of the Big Three.

Thus, in this respect, our analysis agrees with those academic commentators engaging with our work who argue that the large stakes the Big Three managers hold in many portfolio companies give them meaningful incentives to invest in stewardship. ${ }^{59}$ However, those commentators do not recognize the key point established by our analysis above: Even when the stewardship investments of the Big Three are significant, they can be expected to be significantly lower than the investment levels that are desirable for the beneficial investors of the index fund.

For example, Patrick Jahnke has argued that the large stakes that the Big Three hold in many companies "ensures sufficient return on any governance investment." 60 However, our analysis indicates that this "sufficient return" view is incorrect. Because the Big Three capture just a small fraction of the benefits to their beneficial investors produced by investment in stewardship,

59. See, e.g., Fisch et al., supra note 16 (manuscript at 15) ("The size of the Big Three enables them to capture outsize benefits from [investments in corporate governance]."); Patrick Jahnke, Ownership Concentration and Institutional Investors' Governance Through Voice and Exit, 21 Bus. \& Pol. 327, 338 (2019) ("[T]he Big Three asset managers have such large asset bases . . . that the cost of engagement is minimal when compared to the profits they generate." (footnote omitted)); Kahan \& Rock, supra note 16, at 15 (noting that "even these low fees [of index fund managers] generate incentives in the context of voting that compare favorably to those of most other shareholders because the principal advisors to equity index funds are very large ...."). In this respect, we take a different view than that of the critics of index fund managers who argue that such managers follow an "unthinking" mode of operations because of their lack of any incentives to invest in stewardship. See, e.g., Lund, supra note 16, at 513 ("[P] assive fund managers will be especially likely to adhere to $\mathrm{a}[\mathrm{n}]$... unthinking approach to governance ....").

60. Jahnke, supra note 59, at 329 (citing Fichtner et al., supra note 2). 
our analysis above indicates that the private returns from stewardship to the index fund manager would generally be insufficient to induce the level of stewardship investment that would best serve the interests of beneficial investors. This insight follows from the general economic insight that an economic agent who captures only a fraction of the benefits of an activity can be expected to underinvest in this activity, and to set the activity at a suboptimal level. ${ }^{61}$

\section{The Limited Effects of Competition for Funds}

So far, our analysis has assumed that index fund managers take their assets under management and fees as given. We now relax this assumption and examine how the competition to attract assets affects index fund managers' incentives to invest in stewardship. We first discuss competition with other index funds and then turn to competition with actively managed funds.

To begin, an index fund manager faces clear and direct competition with other index fund managers. ${ }^{62}$ An investor in a given index fund could choose to invest instead in an index fund run by another manager that tracks the same or a similar index. Index fund managers thus have an incentive to make their funds as attractive as possible, and to perform as well as possible, relative to other index funds.

However, competition with other index funds tracking the same index gives index fund managers precisely zero additional incentive to invest in stewardship for any of their portfolio companies. If the index fund manager invests in stewardship that increases the value of a particular portfolio company, the increase will be shared with all other investors in the company, including rival index funds that replicate the same index. These rival index funds will capture the same benefit even though they have not themselves made any additional investment in stewardship. An index fund manager's

61. This is a version of the general issue of private production of an activity that has positive external benefits on others that the private producer is unable to capture. A canonical example is that of a lighthouse; for a discussion of the history of this example and the underlying concept by Ronald Coase, see R.H. Coase, The Lighthouse in Economics, 17 J.L. \& Econ. 357, 357 (1974).

We are grateful to Alon Brav, the discussant of our Working Paper at the NYU Roundtable, for encouraging us to stress this difference between the conclusions of our analysis and the positions of commentators taking issue with our view.

62. For a study showing that the flow of assets into investment funds is significantly influenced by performance relative to investment fund managers operating similar funds, see Erik R. Sirri \& Peter Tufano, Costly Search and Mutual Fund Flows, 53 J. Fin. 1589, 15981601, 1619 (1998) (finding that "consumers of equity [mutual] funds disproportionately flock to high performing funds"). 
investment in stewardship will therefore not result in any increase in the fund's performance compared to that of its rivals, and will not allow the fund to attract investments from its rivals or to increase its fee levels. ${ }^{63}$

The index fund manager cannot even increase its fees or expenses to cover the cost of the investment in stewardship: Since its gross returns are the same as those of rival index fund managers, if it increases its fees or expenses, its net returns will be below those of its rivals. Stewardship will therefore not provide any competitive benefits to index fund managers and will not give them any incentive to ameliorate their underinvestment in stewardship from the level described in section I.D.2.

Finally, while the above analysis has implicitly assumed that index fund investors care exclusively about the financial return from their investment, some index fund investors might well have a preference for investing with an index fund manager whose stewardship activities they view favorably, or at least not unfavorably, and may expect index fund managers with which they invest to be good stewards. The more widely held these preferences are, the stronger the index fund managers' incentives to be perceived as good stewards. But incentives to be perceived as good stewards are quite different from incentives to make desirable stewardship decisions.

Investors may not recognize certain deviations from optimal stewardship decisions. As a result, accommodating their preferences would not necessarily discourage suboptimal stewardship. Although the interest of index fund managers in being perceived as good stewards cannot eliminate such deviations, it can be expected to affect index fund manager behavior, in a way that we will return to in section I.F, below.

Turning to competition with actively managed funds, Jill Fisch, Assaf Hamdani, and Steven Davidoff Solomon have recently offered support for index fund stewardship, arguing that index fund managers compete for funds "not only with each other but also with ... active funds," and that this competition provides them with "the incentive to improve the governance of companies in their portfolio." ${ }^{64}$ According to this view, by improving the governance of public companies, index fund managers may eliminate potential advantages that actively managed funds may have-advantages that

63. In this respect, index funds are different from actively managed funds. For analyses of how the stewardship incentives of actively managed funds are influenced by competition with other actively managed funds, see Bebchuk et al., Agency Problems of Institutional Investors, supra note 15, at 97-100 (theoretical analysis), and Jonathan Lewellen \& Katharina Lewellen, Institutional Investors and Corporate Governance: The Incentive to Be Engaged 13-28 (Tuck Sch. Bus., Working Paper No. 3265761, 2018), https://corpgov.law.harvard.edu/wp-content/uploads/2019/11/Jonathan-LewellenKatharina-Lewellen.pdf [https://perma.cc/MX7P-AEGD] (empirical analysis).

64. Fisch et al., supra note 16 (manuscript at 12). 
may otherwise provide those funds with opportunities to outperform index funds. ${ }^{65}$ But as we explain below, this argument provides little basis for expecting index fund managers to have significant incentives to invest in stewardship.

A key driver of the movement from actively managed funds to index funds has been the understanding, backed by empirical evidence in the financial literature, that actively managed funds significantly underperform index funds on average. ${ }^{66}$ To the extent that this understanding leads investors to switch from actively managed funds to index funds, the relevant competition for any given index fund manager is other index funds that track the same or similar indexes.

Of course, substantial assets under management are still invested in actively managed funds; this is mainly because, even though actively managed funds underperform (on average) whichever index they use as a benchmark, some such funds do outperform these indexes. ${ }^{67}$ As Fisch, Hamdani, and Davidoff Solomon note, some actively managed funds "continue to attract substantial new assets" despite the existence of lowerpriced index funds. ${ }^{68}$ Importantly for our purposes, even if index fund stewardship increases value in some or all of their portfolio companies, some actively managed funds will still outperform their benchmark indexes. The constituent companies in any given index can be expected to perform very differently, depending on their industry and the success of their strategies, services, and products. Active managers that disproportionately hold positions in companies that outperform the index will outperform index funds that track that index.

Indeed, to the extent that stewardship by index fund managers brings about expected governance gains in a subset of portfolio companies, those

65. See, e.g., id. at 16 (“[Passive funds] lack . . . active funds" ability to generate alpha through investment choices. Passive investors also do not have the firm-specific information or expertise necessary to address operational issues. Instead, passive investors compete by using their voice and seeking to improve corporate governance.").

66. See, e.g., Russ Wermers, Mutual Fund Performance: An Empirical Decomposition into Stock-Picking Talent, Style, Transactions Costs, and Expenses, 55 J. Fin. 1655, 165556 (2000) (reporting that "the majority of studies now conclude that actively managed funds ... on average, underperform their passively managed counterparts").

67. For studies by financial economists on such occasional outperformance, see, for example, Jonathan B. Berk \& Jules H. van Binsbergen, Mutual Funds in Equilibrium, 9 Ann. Rev. Fin. Econ. 147, 158-62 (2017) (describing evidence regarding the relationship between management skill and investor performance); Hyunglae Jeon, Jangkoo Kang \& Changjun Lee, Precision About Manager Skill, Mutual Fund Flows, and Performance Persistence, 40 N. Am. J. Econ. \& Fin. 222, 229-36 (2017) (describing evidence regarding the effects of imprecision in management skill).

68. Fisch et al., supra note 16 (manuscript at 14). 
active managers that disproportionately hold those companies in their portfolios will outperform the index. As a result, an interest in lowering the performance of actively managed funds relative to index funds should not be expected to provide index fund managers with substantial incentives to undertake value-maximizing stewardship. ${ }^{69}$

\section{E. Incentives to Be Excessively Deferential}

Section I.D discussed one key dimension of stewardship decisions: the choice of how much to spend on stewardship investments and the incentives that index fund managers have to underinvest in stewardship. In this section we turn to a second key dimension: the choice between deference to corporate managers and nondeference. As we show, the private interests of index fund managers are likely to affect their deference-nondeference choices in ways that could well distort these choices. Below we first discuss this issue in general; we then proceed to discuss three significant ways in which the private interests of index fund managers, and especially the Big Three, could be served by being excessively deferential. ${ }^{70}$

\section{The Value-Maximization Benchmark}

The second important dimension, which is qualitative in nature, is the level of deference that index fund managers give to the views and preferences of the managers of their portfolio companies. Such deference-nondeference decisions include whether to vote for or against a company's say-on-pay

69. For additional criticisms of the argument that the desire to compete with actively managed funds encourages stewardship by index funds, see generally J.B. Heaton, All You Need Is Passive: A Response to Professors Fisch, Hamdani, and Davidoff Solomon (July 7, 2018) (unpublished manuscript), https://ssrn.com/abstract $=3209614$ (on file with the Columbia Law Review). Other prominent commentators who generally look favorably at index fund stewardship take issue with the argument by Fisch et al., supra note 16 (manuscript at 6,12-20), that competition with actively managed funds provides substantial incentives for stewardship. See Kahan \& Rock, supra note 16, at 26-28.

70. In a response to this Working Paper provided to the Financial Times, an SSGA representative expressed doubt with respect to our excessive deference questions, stating that "I doubt that you would be able to obtain a company that says that State Street is a pushover." See Owen Walker, BlackRock, Vanguard and SSGA Tighten Hold on US Boards, Fin. Times (June 15, 2019), https://www.ft.com/content/046ec082-d713-3015-beaf-c7fa42f3484a (on file with the Columbia Law Review). But even if a given company's managers were to view SSGA as a "pushover," their interests would be best served by not stating this belief, and instead not questioning the effectiveness of the investor oversight to which they are subject. Furthermore, and importantly, the SSGA officer's response does not engage with our analysis in this section regarding the three drivers of excessive deference that we identify, nor with the evidence consistent with excessive deference provided in Part II. 
proposal; whether to vote for or against a company's director slate in a proxy contest against an activist; whether to support or withhold support from the directors on the company slate in uncontested elections; whether to vote for or against shareholder proposals opposed by the managers of a company; and whether to submit shareholder proposals to a company. Deferencenondeference decisions may also involve the choice of general principles, policies, or practices that apply to a wide range of situations, such as proxy voting guidelines. $^{71}$

Some deference-nondeference decisions - such as voting - are purely qualitative; they will involve the same resource cost regardless of the level of deference chosen. For other decisions - such as submitting a shareholder proposal - the nondeferential choice requires greater resources. While there is thus some interaction between the choice of investment level and the choice between deference and nondeference, we discuss the two choices separately for the sake of conceptual clarity. Similarly, for simplicity of exposition, we discuss deference-nondeference as a binary decision, but the insights from our analysis are equally applicable to situations in which the level of deference involves a range of choices.

What is the deference-nondeference decision that would be valuemaximizing for index fund investors? In many cases, the positions preferred by corporate managers would be viewed independently as value-enhancing by the index fund manager. In some cases, the index fund manager may be uncertain, but may rationally conclude that deferring to the views of corporate managers would likely be value-enhancing because of the corporate managers' superior information.

In some other cases, however, deferring to corporate managers may not be value-enhancing. Nondeference will be value-enhancing if and only if its expected effect on the value of the index fund's position in the portfolio company would be positive. Formally, we denote the expected change in value from nondeference as $\Delta V_{N D}$. The change in value from nondeference, $\Delta V_{N D}$, can be positive if certain deferential actions are value enhancing for the company, but there can also be a loss from nondeference if deference to portfolio company managers would be the best course of action in a particular case. That is, nondeference will be value-enhancing if and only if $\Delta V_{N D}>0$.

When an index fund manager faces a binary choice between deference and nondeference to a particular portfolio company's managers, value-

71. For simplicity, this section's analysis assumes that the deference decision consists of a binary choice: deference or nondeference. To be sure, in many situations, investors face a continuum of choices and thus can be viewed as choosing the level of deference within a range of possible levels. An analysis assuming that investors set the level of deference within a continuum of possible choices yields a qualitative similar conclusions to the one presented below: that index fund managers will have an incentive to be excessively deferential to corporate managers. 
maximizing stewardship calls for nondeference whenever the expected value effect from nondeference is positive, and for deference whenever the expected value effect from nondeference is negative. But the choice between deference and nondeference may also be influenced by the private interests of the index fund manager in ways that we discuss in sections I.E.2-I.E.4 below.

Let us suppose the expected change in the value of the portfolio from nondeference, $\Delta V_{N D}$, is positive, so nondeference would be desirable for the beneficial investors in the index fund, but that nondeference imposes costs of $C_{N D}$ on the index fund manager. The index fund manager captures only the fractional fee $(\theta)$ of the expected gain from nondeference: $\theta \times \Delta V_{N D}$. Even though nondeference is value-maximizing it does not benefit the index fund manager when $C_{N D}>\theta \times \Delta V_{N D}$. Thus, costs to index fund managers from nondeference create a distortion: Value-enhancing nondeference would not serve the interests of index fund managers if and only if:

$$
0<\Delta V_{N D}<C_{N D} / \theta \text {. }
$$

It is useful to note the role that the fractional fee of $\theta$ plays in determining the range of situations in which the index fund manager will have distorted incentives. Because the value of $\theta$ is likely to be very small for index fund managers, $C_{N D} / \theta$ will likely be higher, and the range of distorting situations will likely be wider. Because the fractional fee of $\theta$ is likely to be very small, the expected gain from nondeference of $\Delta V_{N D}$ gets a substantially reduced weight in the calculus of index fund managers' incentives, and is thus more likely to be outweighed by private costs from nondeference.

To illustrate, consider again the index fund with a $\$ 1$ billion position, an expected gain from nondeference of $0.1 \%$ (that is, $\$ 1$ million), and a fractional fee of $1 \%$. In this case, even though nondeference would be valueenhancing, it would be against the interests of the index fund manager if the cost of nondeference exceeds $\$ 10,000 .^{72}$

The practical significance of distortions from private costs of nondeference depends on the extent of those costs. In sections I.E.2 through I.E.4 we consider, in turn, the significance of three sources of costs: (i) business ties with public companies, (ii) legal requirements that nondeferential index fund managers make Schedule 13D disclosures, and (iii) the risk that, by "stepping on the toes" of corporate managers or by making their own power more salient, the Big Three could trigger a managerial and regulatory backlash.

72. In the second example used in section I.D. 1 , when the expected gain is only $0.01 \%$, nondeference would be against the interests of the index fund manager as long as the private cost of nondeference is greater than $\$ 1,000$. 


\section{Business Ties with Corporate Managers}

Index fund managers, including the Big Three, have a web of financiallysignificant business ties with corporate managers, so they may pay close attention to how corporate managers perceive them. One important source of investment manager revenue that has received considerable attention relates to defined contribution plans, commonly referred to as "401(k) plans."73 The assets under management in $401(\mathrm{k})$ plans are very large, and a majority of those assets are held in mutual funds. ${ }^{74}$ Index fund managers derive a substantial proportion of their revenues from $401(\mathrm{k})$ plans,${ }^{75}$ in two ways: (i) by providing administration services to such plans, ${ }^{76}$ and (ii) by having their index funds included in the menu of investment options available to plan participants. $^{77}$

Index fund managers can reasonably expect that the extent to which corporate managers view them favorably might influence their revenues from 401(k) plans. In public companies a committee of employees often chooses the plan administrator and the menu of investment options. ${ }^{78}$ Although these choices are subject to fiduciary duties, the decisionmakers often have a number of reasonable choices, and in such cases the views and preferences of corporate managers could influence these employees' decisions.

73. 401(k) plans are so called for $\S 401(\mathrm{k})$ of the Internal Revenue Code governing the tax treatment of "qualified cash or deferred arrangement[s]." I.R.C. § 401(k) (2012).

74. For evidence on the scale of assets in 401(k) plans, and the substantial proportion invested in mutual funds, see generally Sean Collins, Sarah Holden, James Duvall \& Elena Barone Chism, The Economics of Providing 401(k) Plans: Services, Fees, and Expenses, 2016, ICI Res. Persp., June 2017, at 1 (on file with the Columbia Law Review).

75. According to the Pensions \& Investments database, the proportion of U.S. client assets under management for each of the Big Three that came from 401(k) plans in 2017 was $14 \%, 20 \%$, and 17\%, for BlackRock, Vanguard, and SSGA, respectively. See 2018 Survey of Money Managers, Pensions \& Invs., https://www.pionline.com/specialreports/moneymanagers/20180528 [https://perma.cc/E2N2-LHD8] (last visited July 11, 2018).

76. As of December 31, 2018, Vanguard (\$454 billion in plan assets) was the fourthlargest provider of plan administration services, after Fidelity, TIAA, and Empower Retirement. See 2019 Recordkeeping Survey, Plansponsor (July 18, 2019), https://www.plansponsor.com/research/2019-recordkeeping-survey/ (on file with the Columbia Law Review). A substantial proportion of these plan assets are likely to be associated with public companies.

77. For evidence that an index fund that provides administration services is also more likely to have its funds appear on the menus for 401(k) investments, see Veronika K. Pool, Clemens Sialm \& Irina Stefanescu, It Pays to Set the Menu: Mutual Fund Investment Options in 401(k) Plans, 71 J. Fin. 1779, 1787 tbl.2 (2016).

78. For smaller companies, the plan fiduciary is a staff member in the company's human resources or finance department. For a discussion of plan fiduciaries, see Stephen Davis, Jon Lukomnik \& David Pitt-Watson, What They Do with Your Money: How the Financial System Fails Us and How to Fix It 104 (2016). 
Furthermore, the incentives discussed below arise even if decisions are often not influenced by the preferences of corporate managers, so long as index fund managers believe that such influence might sometimes have an effect.

Turning to analyze how business ties provide incentives for deference, we would like to distinguish two types of effects of business ties on deference-nondeference decisions. The first type of effect, client favoritism, has received significant attention in the literature, ${ }^{79}$ though - for the reasons discussed below-we view it as less important. Index fund managers may be more deferential to managers of particular companies with which they have (or hope to have) business ties than they are to managers of other companies. For example, an index fund manager may have incentives to support the sayon-pay proposal of a company that is a current or potential client, even if that index fund manager would vote against such a proposal at other companies.

Indeed, client favoritism is consistent with the empirical evidence; for example, a recent study by Dragana Cvijanović, Amil Dasgupta, and Konstantinos Zachariadis finds that investment managers are more likely to vote in support of portfolio company managers on closely contested proposals when the investment manager has significant business ties to the portfolio company. ${ }^{80}$

Responding to questions about client favoritism issues, some investment fund managers, including the Big Three, have put in place internal "walls" separating stewardship personnel from the individuals who maintain and cultivate business ties. For example, SSGA publishes "Conflict Mitigation Guidelines" that explain how SSGA's stewardship team is insulated from others within the organization whose role is to develop and maintain business ties with corporate managers. ${ }^{81}$ Even assuming that internal walls can be expected to eliminate the issue of client favoritism completely, such walls

79. For early works discussing this type of effect, see, for example, John Brooks, Corporate Pension Fund Asset Management, in Abuse on Wall Street 224, 231-40 (The Twentieth Century Fund 1980); Black, Shareholder Passivity Reexamined, supra note 17, at 596-98; Coffee, supra note 17, at 1321-22; Gerald F. Davis \& Tracy A. Thompson, A Social Movement Perspective on Corporate Control, 39 Admin. Sci. Q. 141, 161-62 (1994); Rock, supra note 17, at 469-72. For a current discussion of this type of conflict, see Sean J. Griffith \& Dorothy S. Lund, Conflicted Mutual Fund Voting in Corporate Law, 99 B.U. L. Rev. 1151, 1181-86 (2019).

80. Dragana Cvijanović, Amil Dasgupta \& Konstantinos E. Zachariadis, Ties that Bind: How Business Connections Affect Mutual Fund Activism, 71 J. Fin. 2933, 2933 (2016) (finding that "business ties significantly influence promanagement voting at the level of individual pairs of fund families and firms").

81. 2019 State Street Global Advisors Conflict Mitigation Guidelines, State St. Glob. Advisors (Mar. 18, 2019), https://www.ssga.com/na/us/institutional-investor/en/ourinsights/viewpoints/2019-ssga-conflict-mitigation-guidelines.html [https://perma.cc/6ZXXRMYQ]. 
cannot eliminate other issues arising from business ties.

In particular, although client favoritism has thus far received the most attention, ${ }^{82}$ we would like to highlight another key channel that we view as the most important for incentivizing deference. Setting general principles, policies, and practices more deferentially enhances the likelihood that corporate managers will view the index fund manager more favorably and does so without producing any inconsistency in the treatment of clients and nonclients. For example, rather than tending to vote at particular client companies in ways that managers of those companies are likely to prefer, an index fund manager can set its general principles, policies, and practices to enhance the likelihood of supporting management in votes across all portfolio companies. This reduces the likelihood that current or potential clients will receive negative votes and therefore view the index fund manager unfavorably.

We refer to this issue as "general management favoritism," by contrast to client favoritism, because it involves the manager's interest in business ties to induce the manager to be excessively deferential not only toward managers of companies with which the manager has business ties but toward corporate managers of public companies in general. We note the existence of empirical evidence that is consistent with this issue. In particular, empirical studies indicate that investment fund managers that have greater business ties with issuers are more likely to vote in ways that favor managers not only at client companies but at companies in general. In particular, Rasha Ashraf, Narayanan Jayaraman, and Harley Ryan show that, in voting on executive pay in public companies, the volume of business that investment managers receive from companies is associated with voting more frequently in support of corporate managers. ${ }^{83}$ Similarly, a study by Gerald Davis and E. Han Kim documented that, in voting on shareholder proposals in public companies, "[a]ggregate votes at the fund family level indicate a positive relation between business ties and the propensity to vote with management." 84

82. For studies considering the issue of client favoritism, see supra note 80 .

83. See Rasha Ashraf, Narayanan Jayaraman \& Harley E. Ryan, Jr., Do Pension-Related Business Ties Influence Mutual Fund Proxy Voting? Evidence from Shareholder Proposals on Executive Compensation, 47 J. Fin. \& Quantitative Analysis 567, 587 (2012).

84. Gerald F. Davis \& E. Han Kim, Business Ties and Proxy Voting by Mutual Funds, 85 J. Fin. Econ. 552, 569 (2007) (examining voting on shareholder proposals and documenting that "the more business ties a fund company has, the less likely it is to vote in favor of shareholder proposals that are opposed by management ... although individual votes appear evenhanded, business ties affect the overall voting practices at the fund family level"). For an additional empirical article based on evidence from another jurisdiction that shows general favoritism reflected in an association between the business of institutional investors and more pro-insider voting, see Assaf Hamdani \& Yishay Yafeh, Institutional Investors as Minority Shareholders, 17 Rev. Fin. 691, 700-13 (2013) (presenting evidence that 
Importantly, the general management favoritism we discuss could make an index fund manager's stewardship more deferential than desirable substantially beyond the subset of companies that are current or potential clients. Such general management favoritism will affect the stewardship decisions of index fund managers with respect to public companies in general. Furthermore, because decisions influenced by general management favoritism do not manifest themselves in favoritism toward existing clients, this issue cannot be addressed by internal walls and other policies aimed at avoiding client favoritism. ${ }^{85}$ The breadth of this effect, and the difficulty of addressing it through such policies, strengthens questions about distortions of the deference-nondeference decisions of index fund managers. Although commentators taking issue with our views discuss the issue of client favoritism, they have thus far not engaged with our identification of general management favoritism as the issue that is likely to be more costly and substantial. ${ }^{86}$

\section{The Private Costs of Section 13(d) Filer Status}

We now turn to a substantial cost of nondeference for the Big Three that arises from the very large number of companies in which they hold stakes of 5\% or more: 2,330 companies (BlackRock), 2,004 companies (Vanguard), and 183 companies (SSGA). ${ }^{87}$ For all of these companies, the Big Three have incentives to avoid any nondeference that would require filing on Schedule $13 \mathrm{D} .^{88}$

Under Section 13(d) of the Securities and Exchange Act, an investor that obtains more than $5 \%$ of a public company is required to make certain disclosures, either on Schedule 13D or on Schedule 13G. ${ }^{89}$ The criterion for

institutions that are potentially conflicted are more likely to vote for insiders proposals than are standalone investors).

85. See supra note 83 .

86. For articles by such commentators, see generally Fisch et al., supra note 16; Kahan \& Rock, supra note 16.

87. See infra section II.B.2. Calculations are based on data from FactSet Res. Sys., Ownership Database (last visited Oct. 3, 2019), and are as of June 30, 2019.

88. For early discussions of the possibility that section 13(d) could deter stewardship, see Alfred F. Conard, Beyond Managerialism: Investor Capitalism Symposium: Issues in Corporate Governance, 22 U. Mich. J.L. Reform 117, 161-63 (1988); Mark J. Roe, A Political Theory of American Corporate Finance, 91 Colum. L. Rev. 10, 26 (1991) [hereinafter Roe, A Political Theory].

89. See 15 U.S.C. $§ 78 \mathrm{~m}(\mathrm{~d})$, (g) (2012); 17 C.F.R. $§ 240.13 \mathrm{~d}-1$ (b) (2019). For an analysis of the law and economics of blockholder disclosure, see generally Lucian A. Bebchuk \& Robert J. Jackson, Jr., The Law and Economics of Blockholder Disclosure, 2 Harv. Bus. L. Rev. 39 (2012). 
whether the investor must make detailed disclosure on Schedule 13D, rather than more limited disclosure on Schedule 13G, is whether the investor makes the acquisition "with the purpose [or] the effect of changing or influencing the control of the [portfolio company]." 90 A number of stewardship activities by index fund managers could be viewed as having such a purpose, including making proposals to sell or restructure the portfolio company, or engaging with the portfolio company to propose or facilitate the appointment of particular individuals as directors.

Schedule 13D filings must be made more frequently and are much more extensive than Schedule 13G filings. Schedule 13D must be filed within ten days after every acquisition and subsequent change in holdings, compared to once per year for Schedule $13 \mathrm{G} .^{91}$ Schedule $13 \mathrm{D}$ filings also require particularized disclosure of each acquisition for each entity, compared to disclosure of aggregated positions for Schedule $13 \mathrm{G} .{ }^{92}$ Schedules $13 \mathrm{D}$ and $13 \mathrm{G}$ apply not just to the index funds managed by the index fund manager but to all the investments for which they have voting power, including actively managed funds and separate client accounts. ${ }^{93}$

Given the frequency of trades in the Big Three's portfolios, making the additional extensive disclosures that Schedule 13D requires would be incredibly costly and time consuming. If a Big Three index fund manager has a position of $5 \%$ or more in a company, nondeference that would require filing Schedule 13D would impose significant costs, which would be borne by the index fund manager rather than by the index fund. Such nondeference would therefore be against the interests of the index fund manager, even though it is desirable for the index fund.

\section{Fears of Backlash}

Finally, we turn to what we believe to be an especially strong factor inducing the Big Three to be excessively deferential to corporate managers: The Big Three's substantial and growing power puts them at risk of public and political backlash that might constrain index fund managers in ways they would find detrimental. ${ }^{94}$ As explained below, deference could reduce the risk

90. 17 C.F.R. $§ 240.13 d-1(b)(1)(i)$. For a general discussion of this rule and the conditions for filing on Schedule 13G, see Arnold S. Jacobs, The Williams Act-Tender Offers and Stock Accumulations $\S 2: 64$ (2019 ed.).

91. 17 C.F.R. $§ 240.13 d-1(a),(b)(2)$.

92. Compare 17 C.F.R. $§ 240.13 d-101$ (Schedule 13D), with 17 C.F.R. $§ 240.13 d-102$ (Schedule 13G).

93. See 17 C.F.R. $\S 240.13 d-3(a)$.

94. For a discussion of the concept of backlash in economic and legal systems generally, and of how the risk of backlash affects decisionmaking, see generally Mark J. Roe, Backlash, 
of such backlash.

The Big Three's dominance of the ever-growing index fund market puts them in a very desirable position. The economies of scale and first-mover advantage that they enjoy provide substantial protection for the dominance of their firms in the index fund marketplace. Are there any clouds on the horizon? Is there anything major that could go wrong for the leaders of the Big Three?

The most significant risk is likely to be a backlash reaction to the growing power of the Big Three. ${ }^{95}$ Business history suggests that the concentration of power over "Main Street" companies in the hands of large "Wall Street" interests can lead to a backlash. Referring to the current period as a "new era of financial capitalism," scholars have compared it to a chapter in American history a century ago in which Wall Street interests, led by J.P. Morgan, wielded substantial power. ${ }^{96}$ But this earlier chapter of finance capitalism ended with a strong regulatory backlash. As Mark Roe's well-known work has documented, vested interests were able to mobilize popular sentiments against the concentrated power of Wall Street financiers, leading to an array of legal rules that curtailed the power of financial blockholders and their ability to intervene on Main Street for decades. ${ }^{97}$

Perhaps most telling for the purposes of our analysis is a more recent chapter of business history that took place in the 1980s and 1990s, when the rise of hostile takeovers led to a backlash that, in turn, produced legislation

98 COLUM. L. Rev. 217 (1998). For a media report discussing questions about the size and power of index funds, see, e.g., Robin Wigglesworth, Passive Attack: The Story of a Wall Street Revolution, FIN. TIMES (Dec. 20, 2018), https://www.ft.com/content/807909e2-032211e9-9d01-cd4d49afbbe3 (on file with the Columbia Law Review) ("[S]ome detractors say that index investing is an insidious disease.").

95. For a recent discussion about the growing concentration of index funds from the founder of Vanguard, see John C. Bogle, Bogle Sounds a Warning on Index Funds, Wall St. J. (Nov. 29, 2018), https://www.wsj.com/articles/bogle-sounds-a-warning-on-index-funds1543504551 (on file with the Columbia Law Review) ("I do not believe that such concentration [of equity investments in the hands of the Big Three] would serve the national interest.").

96. See, e.g., Gerald F. Davis, A New Finance Capitalism? Mutual Funds and Ownership Re-Concentration in the United States, 5 EUR. MGMT. REV. 11, 11 (2008) (stating that the capital markets of the current era have ownership patterns "reminiscent" of those existing in the era of "JP Morgan a century ago"); Fichtner et al., supra note 2, at 299 (remarking that the current concentration of ownership is "reminiscent of the early twentiethcentury" and citing Davis, supra).

97. For an influential work providing a historical account of backlash against Wall Street, see Roe, A Political Theory, supra note 88, at 32-53. 
protective of managers. ${ }^{98}$ Various scholars viewed the possibility of hostile takeovers as potentially beneficial, facilitating the replacement of some underperforming management teams and confronting management teams in general with a disciplinary threat that could provide incentives to be attentive to shareholder interests. ${ }^{99}$ But regardless of their effect on shareholder interests, hostile takeovers threatened the interests of incumbent managers.

As Mark Roe, Roberto Romano, and others have carefully documented, management interests played an important and active role in bringing about a wave of antitakeover legislation in a large majority of U.S. stateslegislation that produced severe impediments to hostile takeovers and provided incumbents with substantial insulation from such threats. ${ }^{100}$ Pressure from advisers affiliated with incumbents also seems to have played a role in encouraging the Delaware courts to develop doctrines that provided incumbents with power to impede hostile takeovers. ${ }^{101}$ It is therefore natural for leaders of the Big Three to consider the risk that their potential stewardship activities could pose a substantial threat to incumbents' power and interests and could thereby lead to a regulatory backlash. Leaders of the Big Three appear to be aware of questions about the power of large index fund managers, ${ }^{102}$ and have made statements that appear to reduce the salience of their power. ${ }^{103}$

98. For an account of this chapter in business history, see Mark J. Roe, Takeover Politics, in The Deal Decade 332-47 (Margaret Blair ed., 1993) [hereinafter Roe, Takeover Politics].

99. For articles discussing the potential benefits of hostile takeovers, see Lucian Arye Bebchuk, The Case Against Board Veto in Corporate Takeovers, 69 U. Chi. L. Rev. 973, 988-94 (2002); Frank H. Easterbrook \& Daniel R. Fischel, The Proper Role of a Target's Management in Responding to a Tender Offer, 94 Harv. L. Rev. 1161, 1165-74 (1981); Henry G. Manne, Mergers and the Market for Corporate Control, 73 J. Pol. Econ. 110, 112-14 (1965).

100. For significant contributions to this line of work, see generally Roe, Takeover Politics, supra note 98, at 338-52; Roberta Romano, The Future of Hostile Takeovers: Legislation and Public Opinion, 57 U. Cin. L. Rev. 457, 458-65 (1988).

101. For a discussion of the evolution of Delaware law in the direction favored by managers, see Roe, Takeover Politics, supra note 98, at 340-47. A famous memo issued by Martin Lipton warned that companies may reincorporate out of Delaware in light of the Delaware Chancery Court's decision in City Capital Assocs. Ltd. P'ship v. Interco Inc., 551 A.2d 787, 799-800 (Del. Ch. 1988). Memorandum from Martin Lipton, Partner, Wachtell, Lipton, Rosen \& Katz, to Clients (Nov. 3, 1988) (on file with the Columbia Law Review). The Delaware Supreme Court subsequently overruled the decision and adopted a position far more protective of incumbents. See Paramount Commc'ns, Inc. v. Time Inc., 571 A.2d 1140, 1153 (Del. 1988).

102. See, e.g., Letter from Cyrus Taraporevala, supra note 33, at 1 (discussing "growing concerns about the influence of large index managers").

103. For a recent release by BlackRock that seems to downplay the power of the Big Three, see Shareholders Are Dispersed and Diverse, BlackRock (Apr. 2019), 
Let us consider how the approach of the Big Three may influence the prospect of public or political backlash. Consider a hypothetical interventional strategy in which the Big Three would seek to improve the value of portfolio companies by (i) making executive compensation incentives more tightly linked to performance, (ii) eliminating antitakeover defenses, (iii) monitoring the business performance of CEOs very closely, and (iv) forcing out CEOs who do not meet a relatively high standard of performance. Let us further assume that the interventional strategy would be expected to enhance the value of the portfolios of the Big Three's funds by about 5\%, and that the Big Three know of this expected beneficial effect.

Of course, it might be argued that the interventional strategy would be value decreasing rather than value enhancing. However, our focus here is not on debating the merits of the interventional strategy, but rather on showing that the Big Three would have incentives to avoid the strategy even under the assumed scenario in which the strategy is expected to be beneficial for their portfolios and the Big Three know this to be the case.

This interventional strategy would create a significant risk of a backlash. Even though the interventional strategy would be expected to enhance value, managers of portfolio companies would have strong incentives to resist it and to mobilize against the Big Three because of the strategy's effect on their power and private interests. Because managers control the massive resources of Main Street companies, they are a formidable foe in the political arena. ${ }^{104}$

Furthermore, management interests could be expected to receive substantial public support. Even though we have stipulated that the interventional strategy is expected to enhance value, this fact would not be incontestable, and it may not necessarily be salient to the public. To the contrary, corporate managers, and the groups, advisors, and researchers associated with them, would be expected to argue forcefully that the interventional strategy would destroy value. They may claim that the Big Three would be excessively micromanaging or second-guessing the business decisions of well-informed managers, creating distraction, or pressuring them

https:/www.blackrock.com/corporate/literature/whitepaper/policy-spotlight-shareholdersare-dispersed-and-diverse-april-2019.pdf [https://perma.cc/W8C5-RAMA] ("[I]ndex funds and ETFs represent less than 10\% of global equity assets. . . As of year-end 2017, Vanguard, BlackRock, and State Street ... represent a minority position in the $\$ 83$ trillion global equity market." (footnote omitted)).

104. For a study of the political power of corporate managers in a historical context, see Roe, A Political Theory, supra note 88, at 45-48. For an article coauthored by one of us that develops a formal model of this issue and highlights the importance of the large resources of public companies for the political influence of the managers of such companies, see generally Lucian A. Bebchuk \& Zvika Neeman, Investor Protection and Interest Group Politics, 23 Rev. Fin. Stud. 1089 (2010). 
toward short-termism. Indeed, business history suggests that public opinion would view with suspicion any substantial concentration of power over Main Street companies by financial decisionmakers. ${ }^{105}$

Thus, pursuing any such strategy whereby the Big Three used their power in ways that impose significant costs on corporate managers would have a significant risk of backlash. Such backlash could lead to the imposition of considerable legal constraints on the power and activities of large index funds and could thereby impose substantial costs on the Big Three. Their leaders therefore have a significant interest in reducing the risk of such backlash.

The Big Three can reduce the risk of a backlash by limiting the extent to which their stewardship constrains the power, authority, compensation, and other private interests of corporate managers. Indeed, a strategy of deference would likely lead corporate managers to be quiet allies rather than foes. With such a strategy, corporate managers could be expected not to resist the increasing equity concentration in the hands of the Big Three but rather to view such concentration as favorable to their own interests. We note that Martin Lipton, who has long been associated with support for takeover defenses and other pro-management positions, has favorably described the increasing influence of index funds. ${ }^{106}$

Substantial nondeference that would involve frequent resistance to choices favored by corporate managers would also increase the salience of the Big Three's power, and with it, potential questions from those parts of the public that are resistant to large concentrations of financial power. Thus, even when significant nondeference would serve the financial interests of index fund investors, index fund managers would recognize that such nondeference could be costly to their private interests by triggering opposition not only from corporate managers but also from parts of the public that are resistant to concentrations of financial power. Thus, as long as excessive deference does not become so salient that it imposes significant reputational costs (as discussed below), deference would serve the interests of Big Three managers by reducing the risk of backlash.

Our analysis above of the private interests of index fund managers identifies three sources of incentives that can induce index fund managers, and in particular the Big Three, to be excessively deferential toward corporate

105. See supra notes 94-101 and accompanying text

106. See, e.g., Lipton, State of Play, supra note 42 (praising the Big Three for their "continued ... support for sustainable long-term investment"); Lipton, New Paradigm for Corporate Governance, supra note 13 (praising the 2018 letter by BlackRock CEO Larry Fink as "a major step in rejecting activism and short-termism"). 
managers. Our empirical analysis, described in Part II, documents evidence that is consistent with the presence of such incentives. But although commentators taking issue with our view have attempted to engage with questions about underinvestment in stewardship, they have thus far not attempted to respond to questions about excessive deference. ${ }^{107}$ Indeed, even those writers who have recently criticized index fund stewardship have tended to focus on questions regarding underinvestment rather than questions regarding excessive deference. ${ }^{108}$

In our view, however, the issue of excessive deference that we analyze and document deserves the close attention of anyone who is interested in index fund stewardship. Indeed, even if index funds were to devote sufficient resources to stewardship, to the extent that their qualitative choices (such as how they vote) are afflicted by excessive deference, that alone would have substantial effects on public companies and on the interests of the funds' beneficial investors.

\section{F. Limits on the Force of Distorting Incentives}

Thus far we have focused on the significant incentives that index fund managers, and especially the Big Three, have to underinvest in stewardship and to defer excessively to corporate managers. We conclude this Part with some comments on two factors that may limit the force and the potentially damaging consequences of these distorting incentives.

\section{Fiduciary Norms}

To begin, in addition to index fund managers' economic incentives, fiduciary norms and individuals' desire "to do the right thing" may well have a significant influence on index fund managers. ${ }^{109}$ This may lead to behavior that is more desirable for their investors than that suggested by a pure incentive analysis. Analyzing the strength of such motivations is beyond the scope of this Working Paper, but we wish to stress that these motivations might have a significant effect on behavior. They should not, however, be expected to eliminate the agency issues we identify, for two reasons.

First, fiduciary norms regarding beneficial investors may sometimes be

107. For articles that engage with the former question but not the latter, see, for example, Fisch et al., supra note 16, at 11 (engaging with arguments regarding underinvestment made in an earlier version of this Working Paper); Kahan \& Rock, supra note 16, at 6 (same).

108. See, e.g., Lund, supra note 16, at 531 (basing a proposal for those investing in passive funds to abstain from voting on the funds" "low-cost" mode of operations rather than any deference inclinations).

109. See, e.g., Booraem, What We Do, supra note 33, at 7 ("[Vanguard] act[s] in the best interest of Vanguard fund investors. Doing the right thing is part of our DNA."). 
in tension with fiduciary norms regarding shareholders. Some index fund managers (including BlackRock and the parent company of SSGA, State Street Corporation) are public companies. Fiduciary norms call for executives of those index funds to maximize the value of the fund management company. For the reasons we have explained in this Part, the value of the fund management company might be maximized by the index fund manager underinvesting in stewardship and displaying deference to the managers of portfolio companies.

Second, and more importantly, the premise underlying most corporate governance arrangements is that incentives matter. If we could rely exclusively on fiduciary norms many key corporate law arrangements would be unnecessary. To illustrate, if fiduciary norms were sufficient to induce desirable behavior by managers, then there would be no reason to adopt executive pay arrangements aimed at generating incentives. The voting guidelines of index fund managers encourage such executive pay arrangements and give significant consideration to the incentives they create in determining how to cast say-on-pay votes. ${ }^{110}$ Thus, even fully accepting that fiduciary norms and a desire to do the right thing play a role in shaping behavior, it remains important to analyze carefully the incentives of index fund managers.

\section{Reputational Constraints}

As we have noted, index fund managers might care about how their stewardship is perceived, not just by the managers of their portfolio

110. See, e.g., BlackRock, BlackRock Investment Stewardship's Approach to Executive Compensation 1 (2019), https://www.blackrock.com/corporate/literature/publication/blkcommentary-our-approach-to-executive-compensation.pdf [https://perma.cc/V479-F5YA] ("The key purpose of executive compensation is to attract, reward, and retain competent directors, executives and other staff . . . with reward for executives contingent at least in part on controllable outcomes that add value"); Vanguard, Proxy Voting Guidelines for U.S. Portfolio Companies 12 (2019), https://about.vanguard.com/investmentstewardship/portfolio-company-resources/proxy_voting_guidelines.pdf [https://perma.cc/4T4Z-KM62] [hereinafter Vanguard, Proxy Voting Guidelines] ("Compensation policies linked to long-term relative performance are fundamental drivers of sustainable, long-term value for a company's investors."); 2019 Proxy Voting and Engagement Guidelines: North America (United States \& Canada), State St. Glob. Advisors (Mar. 18, 2019), https://www.ssga.com/our-insights/viewpoints/2019-proxy-voting-andengagement-guidelines-north-america.html (on file with the Columbia Law Review) [hereinafter State St. Glob. Advisors, Proxy Voting and Engagement Guidelines 2019] ("We support management proposals on executive compensation where there is a strong relationship between executive pay and performance over a five-year period."). We refer to the proxy voting guidelines of each of the Big Three collectively as the "Big Three Proxy Voting Guidelines." 
companies but also by their current and potential customers. ${ }^{111}$ While some index fund investors will choose their index fund manager solely on the basis of financial considerations, other current and potential investors - such as public pension funds, endowments, and individuals with nonfinancial preferences - might also base their choices among index fund managers on nonfinancial considerations. ${ }^{112}$ In particular, such investors might base their choice partly on nonfinancial considerations, such as their perceptions regarding the stewardship quality of the index fund managers they use or are considering.

To the extent that some investors disfavor investing with index fund managers that they believe to be inferior stewards, even if the investors' returns are the same as from other index fund managers, index fund managers will have an incentive to avoid being perceived as inferior stewards. ${ }^{113}$ Thus, index fund managers will have an incentive to emphasize their commitment to stewardship in their public communications. This might also lead index fund managers to take positions on subjects that they expect to appeal to such investors, such as gender diversity on boards and climate change disclosure. $^{114}$

These incentives are also likely to discourage behavior on the part of index fund managers that would make more salient their incentives to underinvest in stewardship or to be deferential to corporate managers. But as we have stressed above, most investors are unlikely to have sufficient expertise or resources to evaluate the many stewardship decisions made by index fund managers. As a result, incentives to avoid being perceived as

111. Vanguard has stated, "We are not a public company, but we must continuously earn and maintain the public trust. We do that by taking a stand for all investors, by treating them fairly, and by giving them the best chance for investment success." Booraem, What We Do, supra note 33 , at 14 .

112. For a recent example of public pension fund clients raising questions about the stewardship activities undertaken by index fund managers, see Jennifer Thompson, Pension Funds Raise Concern over Index Manager Stewardship, Fin. Times (June 23, 2019), https:/www.ft.com/content/f75459e3-3a6d-383e-843b-6c7141e8442e (on file with the Columbia Law Review) ("Passive fund managers are failing to fulfil their stewardship duties, according to their pension scheme clients ....").

113. See, e.g., Booraem, What We Do, supra note 33, at 7 ("In addition to professional investment management, what people expect when they invest in a mutual fund is professional investment stewardship.”).

114. See, e.g., John Gapper, Index Fund Managers Are Too Big for Comfort, Fin. Times (Dec. 12, 2018), https:/www.ft.com/content/ad8c8a12-fd5f-11e8-aebf-99e208d3e521 (on file with the Columbia Law Review) ("The Big Three have realised they cannot keep quiet and hope that no one will notice them."). For a view that passive investors devote attention to stewardship to "boost their firm's image," see Dick Weil, Passive Investors, Don't Vote, Wall St. J. (Mar. 8, 2018), https://www.wsj.com/articles/passive-investors-dont-vote1520552657 (on file with the Columbia Law Review). 
inferior stewards are unlikely to eliminate the many nonsalient ways that the incentives described by the agency-costs view affect the behavior of index fund managers.

Consistent with our analysis that the Big Three have an incentive to make their power less salient, communications by the Big Three have sought to downplay their power. For example, a recent release by BlackRock seeks to challenge views that "index fund managers may wield outsized influence over corporations due to the size of their shareholdings in public companies." 115 The release presents a detailed empirical analysis showing that a large majority of votes are determined by margins larger than the stake held by any given index fund manager. It concludes that "claims that index fund managers are determining the outcome of most proxy votes is not supported by the data." "116 However, a finding that a particular index fund manager frequently does not have decisive power over the outcome of shareholder votes does not imply that the manager does not wield substantial power and influence. Indeed, even though the Big Three managers often do not have decisive power to determine by themselves the outcome of shareholder votes, their significant influence on the outcome leads issuers and their advisors to pay close attention to the Big Three's positions and voting behavior. $^{117}$

115. See Proxy Voting Outcomes: By the Numbers, BlackRock (Apr. 2019), https:/www.blackrock.com/corporate/literature/whitepaper/policy-spotlight-proxy-votingoutcomes-by-the-numbers-april-2019.pdf [https://perma.cc/F6HU-DBJW] [hereinafter BlackRock, Proxy Voting Outcomes].

116. Id.

117. For media reports that pay close attention to the positions of the Big Three, see, for example, Cara Lombardo \& Dawn Lim, Vanguard to Take Tougher Stance Against Overextended Board Members, Wall St. J. (Apr. 11, 2019), https:/www.wsj.com/articles/vanguard-to-take-tougher-stance-against-overextended-

board-members-11554980403 (on file with the Columbia Law Review) (reporting on an update to Vanguard's proxy voting guidelines); Andrew Ross Sorkin, World's Biggest Investor Tells C.E.O.s Purpose Is the 'Animating Force' for Profits, N.Y. Times: Dealbook (Jan. 17, 2019), https://www.nytimes.com/2019/01/17/business/dealbook/blackrock-larryfink-letter.html [https://perma.cc/F5HK-54J5] (reporting on BlackRock CEO Larry Fink's letter to companies).

For posts on the Harvard Law School Forum on Corporate Governance and Financial Regulation by various advisors that report on and expect companies to pay close attention to positions expressed and votes cast by the Big Three, see, for example, Pamela L. Marcogliese, Elizabeth K. Bieber \& Brennan K. Halloran, Cleary Gottlieb Steen \& Hamilton LLP, Synthesizing the Messages from BlackRock, State Street, and T. Rowe Price, Harvard Law Sch. Forum on Corp. Governance \& Fin. Regulation (Feb. 28, 2019), https://corpgov.law.harvard.edu/2019/02/28/synthesizing-the-messages-from-blackrockstate-street-and-t-rowe-price/ [https://perma.cc/96L2-JA9J] (commenting on governance letters issued by BlackRock and SSGA); Ellen J. Odener \& Aabha Sharma, Weil, Gotshal \& Manges LLP, Updated BlackRock Proxy Voting Guidelines, Harvard Law Sch. Forum on 
Similarly, another release by BlackRock seeks to downplay the impact that it and other Big Three managers have on executive pay arrangements. ${ }^{118}$ The release explains that not only do index fund managers not have a decisive impact on whether say-on-pay votes pass, but there are other players that could have more impact. The release stresses that boards of directors, compensation committees, and independent compensation consultants for such committees play important roles in shaping pay arrangements, and that say-on-pay votes are merely "non-binding advisory votes by shareholders." 119 But although say-on-pay proposals are formally nonbinding, issuers seek to avoid having a significant proportion of shares voted against say-on-pay proposals, and they are therefore likely to pay attention to the preferences and positions expressed by shareholders in their say-on-pay votes and in their guidelines with respect to executive compensation. ${ }^{120}$ In any event, putting aside the merits of the substantive arguments in this release, BlackRock's issuance of this release is consistent with our argument that the Big Three have an incentive to downplay and reduce the salience of their power as much as possible.

Finally, we note that this discussion carries significant implications for the potential value of this Working Paper. To the extent that our analysis serves to inform investors of index fund manager incentives and disincentives regarding stewardship quality, it could contribute to reducing deviations from desirable stewardship decisions. We return to this issue in section III.B below.

\footnotetext{
Corp. Governance \& Fin. Regulation (Feb. 9, 2018), https://corpgov.law.harvard.edu/2018/02/09/updated-blackrock-proxy-voting-guidelines/ [https://perma.cc/D86F-Z7V4] (discussing changes to BlackRock's voting guidelines).

118. See Executive Compensation: The Role of Public Company Shareholders, BlackRock (Apr. 2019), https://www.blackrock.com/corporate/literature/whitepaper/ policyspotlight-executive-compensation-the-role-of-public-company-shareholders-april-2019.pdf [https://perma.cc/9N6G-YV8N].

119. Id.

120. The BlackRock release also stresses that proxy advisors have "considerable influence" on the outcome of say-on-pay votes, and might influence $15-25 \%$ of the votes. Id. ("[R]ecommendations by proxy advisory firms can determine between $15-25 \%$ of a sayon-pay vote."). But recent academic work estimates that the influence of proxy advisors is substantially lower than 15-25\%. See Stephen Choi, Jill Fisch \& Marcel Kahan, The Power of Proxy Advisors: Myth or Reality?, 59 Emory L.J. 869, 906 (2010) ("Overall, we consider it likely that an ISS recommendation shifts $6 \%$ to $10 \%$ of shareholder votes ...."). Of course, if a $15-25 \%$ influence amounts to "considerable influence," then the Big Three's shares of votes cast should also be viewed as wielding "considerable influence."
} 


\section{EVIDENCE}

In this Part we turn from theory to evidence. As we stressed in the Introduction, the critical test for any financial and economic theory is empirical. Are the predictions of our incentive analysis borne out? Does the agency-costs view fit and explain the evidence better (or worse) than the value-maximization view? We consider these questions below.

Our empirical investigation puts forward evidence regarding the full range of stewardship activities that the Big Three do and do not undertake. To carry out this investigation we combine data from various providers with hand-collected data; we describe the data sources used in the various empirical analyses of this Part in more detail in the Appendix. We focus on the Big Three because they manage most of the index assets under management by investment managers and because their stewardship reports enable an empirical assessment of their stewardship activities.

Section II.A begins by examining four dimensions of the stewardship activities that the Big Three do undertake, and how they do them. Section II.B then considers five stewardship activities that the Big Three generally do not undertake.

In the course of our analysis, we assess the extent to which the evidence is consistent with the value-maximization and agency-costs views of index fund stewardship. On the whole, the empirical patterns we document in this Part are inconsistent — or at least in tension - with the value-maximizing view. As we explain below, however, these empirical patterns are consistent with - and can be explained by - the predictions generated by the agencycosts view: that index fund managers have considerable incentives to both underinvest in stewardship and defer excessively to corporate managers.

In assessing the evidence on index fund stewardship, we consider arguments that the absence or infrequency of some stewardship activities is consistent with value maximization because such activities are outside the "business models" of the Big Three. As we explain, however, such arguments raise the question of why such activities are outside the business models. The "business models" of the Big Three and the stewardship activities they choose to undertake are not exogenous. Rather, they are a product of choices made by index fund managers, and thus they follow from the incentives that we analyze.

\section{A. What the Big Three Do, and How They Do It}

Section II.A examines what the Big Three do in terms of stewardship, and how they do it. The four dimensions of stewardship activities that we examine are (i) their level of investments in stewardship, (ii) their private 
engagements, (iii) their focus on divergences from governance principles, and (iv) their voting decisions.

\section{Stewardships Budgets and Personnel}

In recent years, the Big Three have substantially increased the resources they devote to stewardship. ${ }^{121}$ Vanguard's stewardship team "has doubled in size since 2015,"122 and in 2018 BlackRock announced its plan "to double the size of [its] investment stewardship team over the next three years."123 The Big Three have also noted the significant numbers of stewardship personnel that they employ, the number of corporate meetings at which they vote, and the number of companies with which they engage. ${ }^{124}$ Supporters of index fund stewardship have viewed these figures as reassuring and promising. ${ }^{125}$

However, any assessment of the Big Three's stewardship activities must consider both the vast number of portfolio companies in which they invest and the many such companies in which they hold substantial stakes with significant monetary value. We conduct such an assessment below and find that it raises significant questions that the Big Three substantially underinvest in stewardship. ${ }^{126}$

121. A survey of investment fund managers conducted in October 2017 showed that, from 2014 to 2017, the number of stewardship team members (excluding environmental, social, and governance (ESG) analysts and portfolio managers of investment teams) increased from twenty to thirty-three at BlackRock, from ten to twenty-one at Vanguard, and from eight to eleven at SSGA. See Bioy et al., supra note 50, at 19 exh.10 (2017), https://www-

prd.morningstar.com/content/dam/marketing/shared/pdfs/Research/Morningstar-PassiveActive-Stewardship.pdf [https://perma.cc/RQY2-F68E].

122. Vanguard, Investment Stewardship 2017 Annual Report 2 (2017), https://about.vanguard.com/investment-stewardship/annual-report.pdf

[https://perma.cc/V8KK-TZ6D] [hereinafter Vanguard, Annual Stewardship Report 2016-7].

123. Fink, supra note 8 .

124. For instance, a senior Vanguard officer stated that, in 2018, "[w] voted [our] funds' proxies at nearly 20,000 meetings and engaged directly with more than 700 portfolio companies." Vanguard, Annual Stewardship Report 2017-18, supra note 45, at 2. Vanguard's then-CEO William McNabb stated that Vanguard's investment stewardship team "held more than 950 engagements with company leaders" in 2017. Vanguard, Annual Stewardship Report 2016-17, supra note 122, at 1.

125. For discussions by commentators taking issue with our view and who favorably cite the Big Three's statements on the scale of their activities, see Fisch et al., supra note 16 (manuscript at 25-26).

126. The data sources and approach used in the empirical analyses in section II.A.1, including the results reported in Tables 1 through 3, are described in section A.1 of the Appendix. 
(a) Current Levels of Stewardship Investment. Table 1 below uses data from Morningstar and the most recent stewardship reports of the Big Three to present the number of stewardship personnel that each manager employs, and the number (or estimates) of portfolio companies that each manages in the United States and abroad.

Table 1. Stewardship Personnel and Portfolio Companies

\begin{tabular}{lccc}
\hline \hline & BlackRock & Vanguard & SSGA \\
\hline $\begin{array}{l}\text { Stewardship Personnel } \\
\begin{array}{l}\text { Portfolio Companies } \\
\text { (Worldwide) }\end{array}\end{array}$ & 45 & 21 & 12 \\
Portfolio Companies (U.S.) & $3,246^{*}$ & 13,225 & $12,191^{*}$ \\
\hline \hline
\end{tabular}

We next estimate the total investment in stewardship by each of the Big Three. We assume, conservatively, that the average cost of each stewardship staff member (including benefits and payroll loading rates) is $\$ 300,000$ per year. ${ }^{127}$ Table 2 shows the estimated cost of each of the Big Three's stewardship departments and that cost as a proportion of the estimated fees from managing these assets. As the Table shows, the estimated investment in stewardship by BlackRock is below $\$ 15$ million, that of Vanguard is below $\$ 10$ million, and that of SSGA is below \$5 million. Importantly, all three stewardship budgets are less than one-fifth of $1 \%$ - only $0.2 \%$ - of the estimated fees that each of the Big Three charge for managing equity assets. Thus, although the Big Three stress the importance of stewardship, their stewardship budgets are economically insignificant relative to the fees that they charge. Clearly, the stewardship budgets of each of the Big Three could be increased multiple times without creating any material funding issue or requiring any material change in fee levels.

127. According to Glassdoor.com, as of October 2019, the average base salary at Blackrock is $\$ 76,273$ for analysts; $\$ 100,196$ for associates; $\$ 132,409$ for vice presidents; $\$ 173,398$ for directors; and \$218,898 for managing directors. See BlackRock Salaries, Glassdoor, $\quad$ https://www.glassdoor.com/Salary/BlackRock-Salaries-E9331.htm [https://perma.cc/C56M-DUQQ] (last visited Oct. 9, 2019). Furthermore, BlackRock's own disclosure indicates that the total median pay for BlackRock employees in 2018 was $\$ 136,313$. BlackRock, 2019 Proxy Statement (Schedule 14A), at 83 (2019). These sources suggest that our assumption of an average per-person cost of $\$ 300,000$ is likely to be conservative. Our understanding from conversations with investment manager employees is that employees in corporate governance positions receive lower salaries, on average, than those in investment positions. 
Table 2. Stewardship Investments Relative to Investment Manager Fees \& Expenses

\begin{tabular}{lccc}
\hline \hline & BlackRock & Vanguard & SSGA \\
\hline Estimated Stewardship Investment (\$m) & $\$ 13.5$ & $\$ 6.3$ & $\$ 3.6$ \\
Estimated Fees \& Expenses (\$m) & $\$ 9,107$ & $\$ 3,467$ & $\$ 2,625$ \\
Stewardship as \% of Fees \& Expenses & $0.15 \%$ & $0.18 \%$ & $0.14 \%$ \\
\hline \hline
\end{tabular}

In addition to stewardship personnel expenses, the Big Three also pay proxy advisors (including ISS and Glass Lewis) for their services. But these payments are unlikely to affect the economic significance of the Big Three's stewardship spending. Furthermore, whereas the Big Three's stewardship operations likely make some use of the reports issued by the proxy advisory firms, Big Three officers regularly stress that they do not defer to proxy advisor conclusions, but rather that they make their own decisions. ${ }^{128}$ Financial economists have empirically confirmed that institutional investors with large assets under management such as the Big Three often do not follow the recommendations of proxy advisors. ${ }^{129}$

128. See, e.g., BlackRock, Stewardship Ecosystem, supra note 28, at 10-11 (presenting data on differences between BlackRock's voting record and the recommendations of Glass Lewis and ISS); Barbara Novick, BlackRock Makes Its Own Proxy-Voting Choices, WALL ST. J. (Sept. 27, 2018), https://www.wsj.com/articles/blackrock-makes-its-own-proxyvoting-choices-1538075415 (on file with the Columbia Law Review) (same); see also Booraem, What We Do, supra note 33, at 11 ("We don't ... vote in lockstep with proxy advisor recommendations."); SEC, Roundtable on the Proxy Process 182 (2018) (comments of Rakhi Kumar, Senior Managing Director and Head of ESG Investments and Asset Stewardship, SSGA), https://www.sec.gov/files/proxy-round-table-transcript-111518.pdf [https://perma.cc/NMU4-VLDS] ("[SSGA] use[s] the proxy advisory firms in three ways. One is to execute our vote guidelines; two, as research insides [sic]; and three, for the operational ease that they provide to their platform.... We have our own voting guidelines ...."); Proxy Voting and Shareholder Engagement FAQ, BlackRock, https://www.blackrock.com/corporate/literature/fact-sheet/blk-responsible-investment-faqglobal.pdf [https://perma.cc/V3MN-A2PX] (last visited Sept. 8, 2019) ("We do not follow any single proxy advisor's voting recommendations.").

129. For empirical evidence that many large investment managers do not follow the recommendations of proxy advisors ISS or Glass Lewis, see Peter Iliev \& Michelle Lowry, Are Mutual Funds Active Voters?, 28 Rev. Fin. Stud. 446, 465-66 (2015) (presenting evidence that index fund voting differs significantly from ISS recommendations); Davidson Heath, Daniele Macciocchi, Roni Michaely \& Matthew Ringgenberg, Do Index Funds Monitor? 10-11 (Swiss Fin. Inst. Research Paper Series, Working Paper No. 19-08, 2019), https://ssrn.com/abstract=3259433 (on file with the Columbia Law Review) (presenting evidence of index funds voting against ISS recommendations for more than $50 \%$ of proposals 
Another important dimension for assessing the levels of investment in stewardship is the amount of personnel time that each of the Big Three dedicates to particular portfolio companies. To estimate this amount, we assume (conservatively) that each stewardship team member works on all weekdays other than federal holidays (that is, they take no vacation or sick days), for a total of 250 workdays per year. We also assume (again, conservatively) that stewardship personnel spend $100 \%$ of their time on "pure" stewardship and no time at all on other activities, such as administration, training, and reporting.

To estimate the amount of personnel time or stewardship budget devoted to a given company we must make assumptions regarding how the Big Three allocate their stewardship time among their portfolio companies. In particular, we examine four different potential allocation scenarios. Scenario 1 assumes that the Big Three divide their stewardship resources equally among all of their portfolio companies. Because our focus is on understanding the quality of corporate governance in U.S. public companies, Scenario 2 assumes (conservatively) that the Big Three spend $75 \%$ of their stewardship resources on U.S. portfolio companies (even though those companies constitute a substantially lower fraction of each manager's total portfolio companies). Because index fund managers are likely to allocate more stewardship time to portfolio companies in which their investments are larger, Scenario 3 calculates how much time and investment the Big Three spend on each $\$ 1$ billion equity position in their worldwide portfolios, and Scenario 4 calculates the stewardship time and investment for each $\$ 1$ billion equity position in U.S. public companies (again assuming that the Big Three devote $75 \%$ of their stewardship resources to U.S. companies).

For each of these four scenarios, Table 3 provides estimates of the amount of personnel time and the dollar cost of this personnel time that the Big Three allocated to stewardship. Table 3 indicates that, no matter the scenario, each of the Big Three spent very limited resources on stewardshipeither in personnel time or in dollar cost - per portfolio company, including for positions of significant monetary value. Even under the most conservative assumptions, in order to oversee each of their billion-dollar positions, BlackRock spent less than 4 person-days per year and less than $\$ 5,000$ in stewardship costs per year, and each of SSGA and Vanguard spent less than 2 person-days per year and less than $\$ 2,500$ in stewardship costs per year.

on which ISS disagrees with company management); Ryan Bubb \& Emiliano Catan, The Party Structure of Mutual Funds 13-14 (Mar. 10, 2019) (unpublished manuscript), https://ssrn.com/abstract=3124039 (on file with the Columbia Law Review) (presenting evidence of variation between Big Three voting and ISS recommendations). In section II.A.4, infra, we provide empirical evidence on the divergence between say-on-pay votes of the Big Three and those recommended by proxy advisors. 
Table 3. Stewardship Per Portfolio Company

\begin{tabular}{lccc}
\hline \hline & BlackRock & Vanguard & SSGA \\
\hline $\begin{array}{l}\text { Stewardship Time (Person-Days) } \\
\quad\end{array}$ & & \\
$\quad \begin{array}{l}\text { Scenario 1: Equal Allocation of Stewardship } \\
\text { Time, per Portfolio Company (Worldwide) }\end{array}$ & 1.00 & 0.40 & 0.25 \\
$\begin{array}{l}\text { Scenario 2: Stewardship Allocated 75\% to U.S. } \\
\text { Companies, per U.S. Company }\end{array}$ & 2.24 & 1.07 & 0.72 \\
$\begin{array}{l}\text { Scenario 3: Proportional Stewardship Allocation, } \\
\text { per \$1bn Position Worldwide }\end{array}$ & 3.71 & 1.36 & 1.94 \\
$\begin{array}{l}\text { Scenario 4: Proportional Stewardship Allocation, } \\
\text { per \$1bn Position in U.S. Companies }\end{array}$ & 3.97 & 1.58 & 1.79 \\
\hline $\begin{array}{l}\text { Stewardship Investment (\$) } \\
\text { Scenario 1: Equal Allocation of Stewardship }\end{array}$ & $\$ 1,200$ & $\$ 476$ & $\$ 295$ \\
$\begin{array}{l}\text { Time, per Portfolio Company (Worldwide) } \\
\text { Scenario 2: Stewardship Allocated 75\% to U.S. } \\
\text { Companies, per U.S. Company }\end{array}$ & $\$ 2,689$ & $\$ 1,287$ & $\$ 866$ \\
$\begin{array}{l}\text { Scenario 3: Proportional Stewardship Allocation, } \\
\text { per \$1bn Position Worldwide }\end{array}$ & $\$ 4,447$ & $\$ 1,635$ & $\$ 2,332$ \\
$\begin{array}{l}\text { Scenario 4: Proportional Stewardship Allocation, } \\
\text { per \$1bn Position in U.S. Companies }\end{array}$ & $\$ 4,762$ & $\$ 1,895$ & $\$ 2,147$ \\
\hline \hline
\end{tabular}

To be sure, it is possible to conceive of many other scenarios for allocating personnel time among portfolio companies. For instance, the Big Three might devote more time to companies that are targets of hedge fund activists and less time to the (many more) companies that are not. Or the Big Three might devote more time to companies that have been afflicted by scandals or that have experienced poor financial performance, and less time to the (many more) companies that have not. While these scenarios would obviously involve shifting personnel time from some companies to others, they would not affect the aggregate personnel resources devoted to stewardship by each of the Big Three reported above. The question we consider is whether these aggregate resources are sufficient for effective stewardship.

(b) Assessing Current Investment Levels. Recall the factors that provide the Big Three with incentives to underinvest in stewardship relative to what would be desirable for their beneficial investors. Given that the Big Three hold positions of about $5 \%$ or more in a large number of significant U.S. 
companies, ${ }^{130}$ with many of these positions worth more than $\$ 1$ billion, it would be in the interest of index fund investors for those portfolio companies to receive significant time and attention from the Big Three's stewardship personnel.

Recall the example, discussed in section I.D.1, of an index fund portfolio with a sole owner-manager and a $\$ 1$ billion investment in a particular portfolio company. In that case it would be in the interests of the index fund's beneficial investors to make additional marginal investments in stewardship up to $\$ 1$ million if such spending could bring about a $0.1 \%$ increase in value. But as we discussed in section I.D, an index fund manager that has a fractional fee of $1 \%$ of assets under management would have an incentive to make additional marginal investments in stewardship up to $\$ 10,000$. The questions raised by this analysis are reinforced by the evidence presented in Table 3. The levels of stewardship described in Table 2 and Table 3 would enable only limited and cursory attention to a large majority of the Big Three's portfolio companies, including those in which they hold positions of significant monetary value.

In assessing these questions, we note that evaluation of the governance and performance of each public company requires reviewing, at a minimum, hundreds of pages of documents each year. These include (i) the annual report and proxy statement, (ii) the company's long term plans and performance, (iii) executive compensation arrangements, and (iv) management proposals and shareholder proposals going to a vote. Investors with large stakes may also want to review other materials, such as analyst reports and proxy advisory assessments. ${ }^{131}$

We consider three possible responses to the above questions. First, it could be argued that our analysis of per-company personnel time assumes that a certain amount of time must be spent with respect to every portfolio company. But many portfolio companies - such as those that do not suffer from a crisis or a major governance or performance issue - arguably may not require any attention or investment in personnel time. In this view, the time saved by ignoring these companies could be devoted to those companies that

130. See infra Table 8.

131. A recent study provides empirical evidence that "the largest five fund families [including the Big Three] access governance-related filings of $29 \%$ of their portfolio firms." Peter Iliev, Jonathan Kalodimos \& Michelle Lowry, Investors' Attention to Corporate Governance 3 (Mar. 6, 2019) (unpublished manuscript), https://ssrn.com/abstract=3162407 (on file with the Columbia Law Review). This finding indicates that Big Three personnel might not even "access" governance-related filings for a majority of their portfolio companies in which they are substantial shareholders. We note that "accessing" governancerelated filings does not by itself indicate that those filings were reviewed in ways that go beyond mere cursory examination. 
do face such major issues with performance. ${ }^{132}$

However, the interests of index fund investors would not be served by ignoring or paying little attention to the majority of public companies that do not obviously suffer from such issues. Monitoring and engaging with such companies could still improve value by addressing issues falling short of a crisis or a governance failure and can also reveal the presence of substantial issues before they become clearly apparent. This is especially the case since the Big Three will generally be among the largest shareholders in the company, and so would have to rely on smaller and potentially less-wellresourced shareholders to identify these issues.

Second, it could be argued that economies of scale (from dealing with many portfolio companies with similar issues) allow the Big Three to spend much less time on any individual company. ${ }^{133}$ When the stewardship staff of a Big Three manager studies an issue that arises in numerous companies, so the argument goes, the staff can apply their conclusions to all of those many companies, thereby spreading the cost of their research. ${ }^{134}$ But even with the use of some generally applicable insights, effective stewardship also requires consideration of detailed, company-specific information, and using that information to make adjustments to general policies. Without such consideration, it is not possible to make decisions that are best suited to the great variation in circumstances of different portfolio companies. ${ }^{135}$

132. We are grateful to Mark Roe for encouraging us to respond to this objection.

133. For versions of this argument by commentators that view index fund stewardship favorably, see, for example, Asaf Eckstein, The Virtue of Common Ownership in an Era of Corporate Compliance, 105 Iowa L. Rev. (forthcoming 2019) (manuscript at 8-9), https://corpgov.law.harvard.edu/wp-content/uploads/2019/11/Asaf-Eckstein.pdf

[https://perma.cc/G26X-RT5R] (arguing that institutional investors can enjoy the benefits of economies of scale with respect to macrolegal risks common to their large portfolio of companies); Fisch et al., supra note 16 (manuscript at 7) (asserting that passive investors are able to spread the cost of obtaining information across their portfolios); Kahan \& Rock, supra note 16, at 34-35 (explaining that investment managers with broad portfolios have economies of scope in considering issues that affect many of those companies). We are grateful to John Coates for stressing the need to respond to this objection.

134. See, e.g., Fisch et al., supra note 16 (manuscript at 26) ("[G]iven the fact that passive funds do not focus on individual firm-specific characteristics, the size of their governance staffs offers substantial manpower to analyze governance issues.").

135. Fisch, Hamdani, and Davidoff Solomon seek to defend the Big Three's existing levels of stewardship investment by arguing that "the total number of employees at many hedge funds, which engage in significantly greater firm-specific research, is not dramatically higher than full-time governance staff at the major passive investors." Id. In making this claim, Fisch, Hamdani, and Davidoff Solomon cite to a media report that activist hedge fund Pershing Square reduced its total number of employees to 46. See id at n.160. But this argument overlooks two critical differences between the stewardship of a Big Three index fund and that of an activist hedge fund such as Pershing Square. 
Consider decisions whether to vote for or against a company's executive compensation arrangements at the company's annual meeting. Clearly, researching compensation arrangements at many companies gives the staff of index fund managers experience and expertise that might reduce the average time they require to make each individual voting decision. But effective assessment of compensation arrangements requires staff members to obtain and assess information about the details of the company's financial performance and compensation arrangements from the company's disclosure documents, and possibly to compare those arrangements to the compensation arrangements of relevant peer companies.

To take another example, consider index fund managers' decisions regarding whether companies have appropriate mechanisms for dealing with various legal and compliance risks. According to one supporter of index fund stewardship, Asaf Eckstein, these decisions are a good example of an activity that involves substantial economies of scale, and could therefore be effectively and inexpensively carried out by a Big Three manager holding positions in many companies. ${ }^{136}$ But the monitoring necessary for these decisions cannot be effectively carried out using general principles augmented with cursory examinations of company-specific information. To illustrate, consider the list of compliance mechanisms that Eckstein argues that pharmaceutical companies should put in place. ${ }^{137}$ Our review of this list

First, each of the Big Three index funds has trillions of dollars of equity investments, whereas Pershing Square managed less than $\$ 10$ billion in assets at the time of the media report. Svea Herbst-Bayliss, Ackman Cuts Staff, Shuns Limelight as He Seeks to Turn Around Fund, Reuters (Jan. 22, 2018), https://www.reuters.com/article/us-hedgefundsackman-exclusive-idUSKBN1FB32Y [https://perma.cc/BW4T-5JN3].

Second, each of the Big Three index funds has hundreds of positions that are valued at more than $\$ 1$ billion, see supra note 55 and accompanying text, whereas an activist hedge fund such as Pershing Square is likely to have less than a handful of such positions at any one time. See Bebchuk et al., Agency Problems of Institutional Investors, supra note 15, at 105. Indeed, as of the end of the month immediately prior to the media report cited by Fisch, Hamdani, and Davidoff Solomon, Pershing Square held positions exceeding \$1 billion in value in only two companies (a position in a third company was valued at $\$ 995$ million). See Pershing Square Capital Mgmt., L.P., Information Table (Form 13F) (Feb. 14, 2018). For these reasons, the stewardship investment level that would best serve the interests of the beneficial investors of each of the Big Three index funds would likely be substantially higher than the level of stewardship investment that would best serve the interest of the beneficial investors of an activist hedge fund such as Pershing Square.

136. For Eckstein's detailed account of this argument, see Eckstein, supra note 133 (manuscript at 30-53).

137. This list includes:

"the establishment of a system to monitor transactions with members of the healthcare community, an improved anti-corruption training program, a third-party due diligence program, independent control functions, creating an office charged with addressing 
indicates that monitoring whether any given company effectively maintains such mechanisms would require obtaining and assessing detailed companyspecific information. ${ }^{138}$

Third, it might be argued that some stewardship activities of the Big Three that are not very expensive may produce benefits in a large number of companies, generating a relatively large impact for the amount spent. For example, the general corporate governance views reflected in the Big Three's proxy voting guidelines and expressed by the Big Three in various communications could affect many companies for a limited per-company cost. ${ }^{139}$ But our analysis does not question that Big Three stewardship produces significant benefits. The issue on which we focus is that, in addition to the stewardship activities that can be undertaken at very low per-company cost, there are some value-enhancing stewardship activities that require consideration of detailed company-specific information. Consistent with the evidence in this section, the Big Three have incentives to underinvest in these activities, such that the total benefit produced by their stewardship is less than would be desirable for their beneficial investors.

reports of misconduct and a dedicated Global Compliance Audit group; as well as improved mechanisms to ensure that no illegal influence will be made through means that seem to be legitimate such as marketing events, educational seminars and medical studies."

Id. (manuscript at 29-30) (footnote omitted).

138. Kahan and Rock, who also take issue with our view, acknowledge that there are many matters in which company-specific information is valuable. See, e.g., Kahan \& Rock, supra note 16, at 36 ("The information that is material to a vote on any particular issue consists of some mix of issue-specific information [and] company-specific information ...."). But they argue that company-specific information is included in proxy statements. See id. at 39 ("[O]n many matters on which company specific information is valuable ... a significant amount of company-specific information and analysis will be publicly disclosed in proxy statements and other campaign materials."). Although we agree that significant company-specific information is provided in proxy statements (as well as in other company disclosures, proxy advisor reports, and other materials), absorbing and evaluating all the relevant company-specific information often requires significant time and attention.

139. Similarly, in a response to an earlier draft of this Working Paper that an SSGA officer discussed with the Wall Street Journal, the SSGA officer stressed the "extensive thought-leadership work that [SSGA] believes influences corporate behavior." Simon Constable, Index-Fund Firms Gain Power, but Fall Short in Stewardship, Research Shows, Wall St. J. (July 8, 2019), https://www.wsj.com/articles/index-fund-firms-gain-power-butfall-short-in-stewardship-research-shows-11562637900 (on file with the Columbia Law Review). Because thought-leadership might improve matters in many companies, it could also produce stewardship benefits for limited per-company cost. 


\section{Private Engagements}

Later in this Part we discuss evidence that the Big Three largely refrain from using valuable stewardship tools. Before doing so, however, we consider the argument that "behind-the-scenes" engagement with portfolio companies is an effective substitute for these other stewardship tools. ${ }^{140}$ Over the last several years, Big Three executives have stressed the central role that private engagement plays in their stewardship, and have expressed their view that private, behind-the-scenes engagement is a superior stewardship tool. ${ }^{141}$ Academic commentators who view index fund stewardship favorably have also emphasized the significance of the private engagement channel. ${ }^{142}$

140. Responding in the same Wall Street Journal article, Vanguard stressed the critical importance of engagement to the Big Three's stewardship activities. Commenting on the evidence we provide on pro-management voting by the Big Three, Vanguard stated that voting is "only one part of the larger corporate governance process. We regularly engage with companies on our shareholders' behalf and believe that engagement and broader advocacy, in addition to voting, can effect meaningful changes that generate long-term value for all shareholders." See id.

141. For comments by senior officers of BlackRock stressing the central role of engagement, see, for example, BlackRock, Investment Stewardship Report: 2017 Voting and Engagement $\quad$ Report 2017 ), https:/www.blackrock.com/corporate/literature/publication/blk-2017-annual-voting-andengagment-statistics-report.pdf [https://perma.cc/WAE4-3CVX] [hereinafter BlackRock, Annual Stewardship Report 2016-17] ("The key to effective engagement is constructive and private communication.”); BlackRock, Stewardship Ecosystem, supra note 28, at 7 ("Engagement is core to our stewardship program."); Matthew J. Mallow \& Jasmin Sethi, Engagement: The Missing Middle Approach in the Bebchuk-Strine Debate, 12 N.Y.U. J.L. \& Bus. 385, 392 (2016) ("Engaging with boards and firm executives . . can bring about change through incremental, non-confrontational means."); Sarah Krouse, David Benoit \& Tom McGinty, Meet the New Corporate Power Brokers: Passive Investors, Wall St. J. (Oct. 24, 2016), http://www.wsj.com/articles/the-new-corporate-power-brokers-passiveinvestors-1477320101 (on file with the Columbia Law Review) ("[M]eetings behind closed doors can go further than votes against management ...."). For similar comments by a senior officer of Vanguard, see Glenn Booraem, Passive Investors, Not Passive Owners, Vanguard (June 20, 2013), https:/global.vanguard.com/portal/site/institutional/ch/en/articles/researchand-commentary/topical-insights/passive-investors-passive-owners-tlor

[https://perma.cc/RS9T-RUT4] ("[Private engagement is] perhaps [the] more important ... component of [Vanguard's] governance program; ... . [it] provides for a level of nuance and precision that voting, in and of itself, lacks ... [and] is where the action is ... [engagement] is the foundation of our Investment Stewardship Program.").

142. For a discussion of private engagements by such supporters, see, for example, Fisch et al., supra note 16 (manuscript at 24-25) ("In recent years, private engagement by mutual funds has grown dramatically.... The engagement of the large passive investors has particularly increased." (footnote omitted)). But Fisch, Hamdani, and Davidoff Solomon do not engage with the evidence provided in this section that such private engagement still takes place in only a small minority of the Big Three's portfolio companies. 
This section therefore examines private engagements. ${ }^{143}$ Any assessment of the significance of the private engagement channel requires an evaluation of the scale and nature of those private engagements undertaken by the Big Three. The annual stewardship reports of the Big Three (which we refer to, collectively, as the Big Three Stewardship Reports) indicate that these managers conduct private communications with hundreds of companies, and supporters of index fund stewardship have highlighted these absolute numbers. ${ }^{144}$ But the number of companies with which the Big Three privately engage should be examined in relation to the very large number of the Big Three's portfolio companies. We undertake such an examination below.

Table 4 reports our findings regarding the proportion of their portfolio companies with which each of the Big Three companies had engagements for each of the last three years, and the average for each of the Big Three over that period. ${ }^{145}$ Panel A of Table 4 shows the proportion of each of the Big Three's portfolio companies with which it had no engagement in each of the last three years. From 2017 through 2019, the average proportion of portfolio companies with no engagement were $88.9 \%$ for BlackRock, $94.2 \%$ for Vanguard, and $94.5 \%$ for SSGA. Thus, on average, the Big Three had no engagement with $92.5 \%$ of their portfolio companies during the period from 2017 through 2019.

143. The data sources and approach used in the empirical analyses in section II.A.2, including the results reported in Table 4, and the assumptions on which those analyses rely, are described in section A. 2 of the Appendix.

144. For such a discussion stressing the number of engagements, see, for example, Eckstein, supra note 133 (manuscript at 43-45).

145. BlackRock's 2017 and 2018 reports divided its engagements by the resource level they involved. "Basic" engagements were "generally a single conversation on a routine matter," and "Moderate" or "Extensive" engagements involved more than one conversation. Basic engagements constituted $56.8 \%$ of BlackRock's 2017 engagements and $67.8 \%$ of its engagements in 2018. See BlackRock, Annual Stewardship Report 2016-17, supra note 141, at 3; BlackRock, Investment Stewardship Report: 2018 Voting and Engagement Report 3 (2018), https://www.blackrock.com/corporate/literature/publication/blk-voting-andengagment-statistics-annual-report-2018.pdf [https://perma.cc/EW6Q-MDWZ]. Vanguard and SSGA did not provide such detail about how their investment of time and resources varied among their engagements.

BlackRock's and Vanguard's Annual Stewardship Reports are for the twelve month period that ended June 30, 2019; SSGA's Annual Stewardship Report is for the 2018 calendar year. Averages for years and managers reported in the table are the average of the proportions in those years, or for those managers, and are not weighted by number of engagements or assets under management. 
Table 4. Private Engagement

\begin{tabular}{ccccc}
\hline \multicolumn{5}{c}{ Panel A: Portfolio Companies with No Engagement } \\
\hline 2017 & Big Three Avg. & BlackRock & Vanguard & SSGA \\
2018 & $94.1 \%$ & $92.5 \%$ & $94.8 \%$ & $95.0 \%$ \\
2019 & $91.8 \%$ & $87.1 \%$ & $94.3 \%$ & $94.0 \%$ \\
Average & $91.6 \%$ & $87.0 \%$ & $93.4 \%$ & $94.4 \%$ \\
\hline \hline \multicolumn{5}{c}{ Panel B: Portfolio Companies with a Single Engagement } \\
\hline \hline Year & Big Three Avg. & BlackRock & Vanguard & SSGA \\
\hline 2017 & $4.0 \%$ & $4.4 \%$ & $3.1 \%$ & $4.6 \%$ \\
2018 & $5.5 \%$ & $7.6 \%$ & $3.4 \%$ & $5.4 \%$ \\
2019 & $6.2 \%$ & $9.7 \%$ & $3.9 \%$ & $4.9 \%$ \\
Average & $5.2 \%$ & $7.2 \%$ & $3.5 \%$ & $5.0 \%$ \\
\hline \hline \multicolumn{5}{c}{ Panel C: Portfolio Companies with Multiple Engagements } \\
\hline \hline Average & Big Three Avg. & BlackRock & Vanguard & SSGA \\
\hline \hline
\end{tabular}

Panel B of Table 4 reports the proportion of each of the Big Three's portfolio companies in each year in with which it had a single engagement. During the period from 2017 through 2019, BlackRock had single engagements with an average of $7.2 \%$ of its portfolio companies, Vanguard $3.5 \%$, and SSGA 5.0\%. On average, over this period, the Big Three held single engagements in a given year with $5.2 \%$ of their portfolio companies on average.

Panel $\mathrm{C}$ of Table 4 shows the proportion of companies in the portfolios of each of the Big Three with which they had multiple engagements in a particular year. From 2017 through 2019, BlackRock had multiple engagements with an average of $3.9 \%$ of its portfolio companies, Vanguard $2.3 \%$, and SSGA $0.6 \%$. On average, the Big Three had multiple engagements with only $2.3 \%$ of their portfolio companies over this period. 
Thus, the Big Three engage with only a small minority of their portfolio companies, and have multiple engagements in a given year with an even smaller minority of companies in their portfolios. The incidence of engagement is especially low for Vanguard and SSGA, which had any engagement with fewer than $6 \%$ of their portfolio companies each year from 2017 to 2019. Although BlackRock's level of engagement was higher, the percentage of its portfolio companies with which it had any engagement in a given year was less than $12 \%$, on average, during the period from 2017 through 2019.

For the large majority of cases in which each of the Big Three had no engagement with the portfolio company, private engagement cannot be argued to have provided a substitute for the use of other stewardship tools. Furthermore, even in those cases in which private engagement did occur, there are reasons to question whether the effectiveness of such private engagement may have been reduced by the Big Three's reluctance to use other stewardship tools. ${ }^{146}$ For example, private communication by a Big Three manager in favor of a given change - either a strategic change, or a governance change such as moving to majority voting or annual electionswould make clear to corporate managers that a substantial shareholder supported the change. But if corporate managers expected that not making the change would cause the Big Three manager to nominate director candidates or submit a shareholder proposal, they would presumably be more likely to make the change. Conversely, current expectations that the Big Three manager will not take such actions if corporate managers do not make such a change (as we discuss below) make private engagement less effective than it could be. ${ }^{147}$

146. For a report indicating that the use of shareholder proposals "ignites and amplifies investors' engagement efforts," see Jackie Cook, The Proxy Process: Raising the Investor $\begin{array}{llllll}\text { Voice to } & \text { Address } & \text { New } & \text { Risks } & 19 & \text { (2019), }\end{array}$ http://www.shareholderforum.com/access/Library/20190208_Morningstar.pdf [https://perma.cc/7VQN-27R5].

147. For instance, in a recent statement of its stewardship priorities, BlackRock has explicitly stated that "[w]e seek to engage in a constructive manner . . ., but we do not [] tell companies what to do .... [W] explain our concerns and expectations [to companies] ... and then allow time for a considered response." BlackRock, Stewardship Engagement Priorities 2019, supra note 46, at 3. But in a separate release, BlackRock officers emphasize that "our patience is not infinite-when we do not see progress despite ongoing engagement, or companies are insufficiently responsive to our efforts . . we will exercise our right to vote against management recommendations." BlackRock, Stewardship Ecosystem, supra note 28, at 7. This statement indicates that, even if BlackRock faces no progress or insufficient responsiveness in an ongoing engagement, BlackRock will consider voting against management recommendations but not initiating a shareholder proposal or nominating directors. 


\section{Focusing on Divergences from Governance Principles}

This section focuses on the substantial extent to which the Big Three's stewardship activities focus on divergences from governance principles. ${ }^{148}$ The practice of comparing the practices and arrangements of portfolio companies with general governance principles is sometimes referred to as "check-the-box" governance. ${ }^{149}$ As we explain below, focusing on divergences from governance principles serves certain private incentives of index fund managers. To be sure, it may sometimes be desirable for investors to make decisions based on how company activities vary from general governance principles. As we explain below, however, some valuemaximizing stewardship decisions require additional company-specific information that goes beyond check-the-box stewardship.

Consider the proxy voting guidelines that the Big Three follow in determining whether to support incumbent directors standing for reelection or to withhold their support. ${ }^{150}$ Each of the Big Three's guidelines lists situations and conditions that would lead to a withhold vote. Our review of these guidelines indicates that, for each of the Big Three, the important decision whether to support a director or withhold support is based exclusively on the existence or absence of certain divergences from good governance principles.

For example, Vanguard's proxy voting guidelines call for withholding votes from one or more directors if the board or a specific director deviates from certain governance principles in one or more specified ways, such as: (i) the board not having a majority of independent directors; (ii) the board not having audit, compensation, nominating, or governance committees that are fully independent; (iii) a specific director serving on five or more public company boards; or (iv) a specific director not attending more than $75 \%$ of board or committee meetings. ${ }^{151}$ BlackRock and SSGA's approaches differ in

148. The data sources and approach used in the empirical analyses in section II.A.3 are described in section A.3 of the Appendix.

149. For uses of the term "check-the-box" in relation to corporate governance, see, for example, Robert A.G. Monks \& Nell Minow, Corporate Governance 172 (5th ed. 2011); Ian R. Appel, Todd A. Gormley \& Donald B. Keim, Passive Investors, Not Passive Owners, 121 J. Fin. Econ. 111, 134 (2016) [hereinafter Appel et al., Passive Investors, Not Passive Owners]; Martin Lipton, Corporate Governance: The New Paradigm, Harvard Law Sch. Forum on Corp. Governance \& Fin. Regulation (Jan. 11, 2017), https:/corpgov.law.harvard.edu/2017/01/11/corporate-governance-the-new-paradigm/ [https://perma.cc/35HH-5P6A].

150. For the Big Three Proxy Voting Guidelines, see supra note 148.

151. For Vanguard's voting guidelines regarding these matters, see Vanguard, Proxy Voting Guidelines, supra note 110, at 3-6 (listing as reasons for withholding votes from directors these and other specified deviations from governance principles). 
some details but are similarly based on comparison with good governance principles. $^{152}$

Furthermore, the Big Three Stewardship Reports indicate that the Big Three's private, behind-the-scenes engagements - when they do occur-also focus on companies that diverge significantly from desirable governance principles. For example, SSGA indicates that its engagement seeks to provide "principles-based guidance." 153 BlackRock indicates that its engagement might occur when a company lags behind its peers on environmental, social, or governance matters; when it is in a sector with a thematic governance issue material to value; or for other reasons that do not include financial underperformance. ${ }^{154}$ Vanguard in turn states that its stewardship focuses on board composition, governance structures, executive compensation, and board processes for oversight of risk and strategy. ${ }^{155}$

In assessing this focus on divergences from governance principles, we do not question the relevance and importance of such divergences for voting or engagement decisions. It is clearly valuable to take information regarding such divergences into account. In our view, however, value-maximizing decisions on these matters would also require consideration of other types of information. As we discuss in sections II.B.1 and II.B.2 below, valuemaximizing voting and engagement decisions would also incorporate detailed information about the business performance of the portfolio company and the qualifications, expertise, and experience of its directors.

Importantly, the proxy voting guidelines of the Big Three call for consideration of detailed company-specific information regarding business performance and the characteristics of particular directors in the case of a proxy contest over director elections between incumbents and a challenger's competing slate. To illustrate, for such contested director elections,

152. For the voting guidelines of BlackRock and SSGA listing their criteria for withholding support from directors, see BlackRock, Stewardship Engagement Priorities 2019, supra note 46; State St. Glob. Advisors, Proxy Voting and Engagement Guidelines 2019 , supra note 110 , at 3 .

153. State St. Glob. Advisors, Annual Stewardship Report 2016-17, supra note 9, at 3.

154. BlackRock, Annual Stewardship Report 2016-17, supra note 141, at 3. In its Investment Stewardship Priorities for 2019, BlackRock lists its five engagement priorities as "Governance," "Corporate Strategy and Capital Allocation," "Compensation that Promotes Long-Termism," "Environmental Risks and Opportunities," and "Human Capital Management," and does not mention financial or operating performance. BlackRock, Stewardship Engagement Priorities 2019, supra note 46, at 2.

155. Vanguard, Investment Stewardship: 2019 Annual Report 4, 29 (2019) [hereinafter Vanguard, Annual Stewardship Report 2018-19], https://about.vanguard.com/investmentstewardship/perspectives-andcommentary/2019_investment_stewardship_annual_report.pdf [https://perma.cc/NAW8CD9G]. 
Vanguard's proxy voting guidelines call for "case-by-case" decisions based on considerations including "[h]ow . . the company [has] performed relative to its peers," and the extent to which the incumbent directors are "well-suited to address the company's needs" compared with the directors proposed by the challenger. ${ }^{156}$ The proxy voting guidelines of BlackRock and SSGA similarly call for using such information for voting in contested elections. ${ }^{157}$ But as we make clear above, the proxy voting guidelines of each of the Big Three do not call for using such considerations and information where the Big Three decide whether to support directors not facing a proxy challenger, which constitute the vast majority of their voting decisions.

Although focusing on divergences from governance principles may not be value-maximizing for an index fund's beneficial investors, it could well serve the private interests of the index fund's managers that we analyzed in Part I, for two reasons. First, the focus on divergences from governance principles enables an index fund manager to avoid focusing significantly on issues such as business performance and the individual characteristics of directors. Assessing these issues would require detailed company-specific information. Focusing on governance principles thus serves the interests of the Big Three in limiting investments in stewardship.

Second, focusing on compliance or divergence relative to governance principles that enjoy broad support avoids the need to make many discretionary decisions or contestable judgments. Instead, the Big Three's decisionmaking is supported by governance best practices that have widespread support. This makes their use of their power less salient, and thus reduces the risk of backlash.

\section{Pro-Management Voting}

Our analysis in Part II raises questions that the Big Three index fund managers have incentives to be excessively deferential to corporate managers when they vote, especially with respect to issues affecting managers' authority and private interests. This section investigates this question

156. Vanguard, Proxy Voting Guidelines, supra note 110, at 5-6.

157. BlackRock's voting guidelines regarding contested elections indicate that they "are assessed on a case-by-case basis. We evaluate a number of factors, which may include: the qualifications of the dissident and management candidates; [and] the validity of the concerns identified by the dissident ...." Blackrock, Proxy Voting Guidelines for U.S. Securities 5 (2019), https://www.blackrock.com/corporate/literature/fact-sheet/blk-responsibleinvestment-guidelines-us.pdf [https://perma.cc/HN3U-2YDJ] [hereinafter Blackrock, Proxy Voting Guidelines]. SSGA's voting guidelines state that they "vote for the election/reelection of directors on a case-by-case basis after considering various factors." State St. Glob. Advisors, Proxy Voting and Engagement Guidelines 2019, supra note 110, at 2. 
empirically by focusing on the voting decisions of the Big Three on say-onpay resolutions, a subject that is close to the hearts of corporate managers. ${ }^{158}$ We find that these voting decisions seem to exhibit pro-management tendencies that are consistent with the predictions of our agency-costs view.

We gather evidence regarding the say-on-pay voting decisions of the Big Three. Table 5 provides evidence of the incidence of "no" votes by each of the Big Three in say-on-pay votes at S\&P 500 companies in each full year since the 2011 adoption of a say-on-pay mandate by the Dodd-Frank Act. ${ }^{159}$ As Table 5 indicates, each of the Big Three very rarely opposed say-on-pay proposals: BlackRock opposed only $2.0 \%$ of such proposals over this period, SSGA $4.5 \%$, and Vanguard 3.0\%. ${ }^{160}$

Table 5 also compares the voting behavior of the Big Three to the recommendations of ISS, the leading proxy advisor. The three columns on the right of Table 5 show the proportion of those say-on-pay proposals that ISS recommended against which each of the Big Three actually voted against. As Table 5 shows, each of the Big Three vote against only a minority of the proposals that ISS recommends against.

158. The data sources and approach used in the empirical analyses in section II.A.4, including the results reported in Tables 5 and 6 , and the assumptions on which those analyses rely, are described in section A.4 of the Appendix.

159. See Dodd-Frank Wall Street Reform and Consumer Protection Act, Pub. L. No. 111203, § 951, 124 Stat. 1376, 1899-1900 (2010) (adding to $\S 14$ A of the Securities Exchange Act of 1934, 15 U.S.C. $\S 78 n-1$ (2012)).

160. For a recent report presenting similar results for a set of companies with especially highly paid CEOs, see Rosanna Landis Weaver, The 100 Most Overpaid CEOs: Are Fund Managers Asleep at the Wheel? 9-13 (2019), https://static1.squarespace.com/static/59a706d4f5e2319b70240ef9/t/5c6edf92971a180d1fef 1597/1550770069046/100MostOverpaidCEOs_2019.pdf [https://perma.cc/3QKS-YVJV]. 
Table 5. Big Three "No" Votes in S\&P 500 Say-on-Pay Votes

\begin{tabular}{ccccccc}
\hline & \multicolumn{3}{c}{ All Proposals } & \multicolumn{4}{c}{$\begin{array}{c}\text { Proposals with ISS “Against” } \\
\text { Recommendation }\end{array}$} \\
& BlackRock & Vanguard & SSGA & BlackRock & Vanguard & SSGA \\
\hline 2012 & $2.5 \%$ & $5.9 \%$ & $3.3 \%$ & $13.0 \%$ & $37.0 \%$ & $18.5 \%$ \\
2013 & $2.0 \%$ & $2.2 \%$ & $2.9 \%$ & $15.0 \%$ & $22.5 \%$ & $30.0 \%$ \\
2014 & $2.3 \%$ & $2.8 \%$ & $6.0 \%$ & $26.5 \%$ & $32.4 \%$ & $55.9 \%$ \\
2015 & $0.7 \%$ & $2.1 \%$ & $4.5 \%$ & $7.5 \%$ & $22.5 \%$ & $35.0 \%$ \\
2016 & $1.6 \%$ & $1.6 \%$ & $5.1 \%$ & $18.9 \%$ & $16.2 \%$ & $43.2 \%$ \\
2017 & $2.8 \%$ & $3.7 \%$ & $5.6 \%$ & $26.7 \%$ & $35.6 \%$ & $48.9 \%$ \\
2018 & $1.9 \%$ & $2.0 \%$ & $3.5 \%$ & $13.5 \%$ & $21.6 \%$ & $30.3 \%$ \\
\hline Average & $2.0 \%$ & $2.9 \%$ & $4.4 \%$ & $17.3 \%$ & $26.8 \%$ & $37.4 \%$ \\
\hline \hline
\end{tabular}

Of course, the patterns displayed in Table 5 are only suggestive and do not demonstrate excessive deference. It could be argued that index fund managers' general support for say-on-pay proposals reflects the adequacy of executive pay arrangements in the vast majority of S\&P 500 companies, that ISS is excessively critical of executive pay arrangements, and that the Big Three serve the interests of index fund investors by voting in support of a majority of say-on-pay proposals that ISS recommends against. But at a minimum, the Big Three's general support for executive pay in the overwhelming majority of S\&P companies is consistent with the deference predictions of the agency-costs view.

To provide another benchmark for comparison, we gathered data on how the investment managers of fund families that are largely actively managed vote on say-on-pay proposals. Table 6 compares the votes of the Big Three with the three largest active managers, Capital Group, Fidelity Investments Inc., and T. Rowe Price Group, Inc., and the ten largest active managers, for each year from 2012 to 2018. As Table 6 shows, the frequency of "no" votes on say-on-pay proposals for the Big Three is less than half (and closer to onethird) of the frequency for the largest three active managers or the largest ten active managers. Of course, it could still be argued that these active managers are excessively critical of executive pay, and that the substantially more deferential voting by the Big Three reflects a better assessment of pay arrangements. Without clear reasons to expect large active managers to be excessively critical and adversarial toward managers of S\&P 500 companies, however, the results reported in Table 6 are consistent with the prediction of our incentive analysis and the agency-costs view: The Big Three's voting 
behavior is likely to be excessively deferential.

Table 6. Big Three and Active Manager "No" Votes in S\&P 500 Say-on-Pay Votes

\begin{tabular}{ccccccc}
\hline \hline & \multicolumn{2}{c}{ Big Three } & \multicolumn{2}{c}{$\begin{array}{c}\text { Largest 3 Active } \\
\text { Managers }\end{array}$} & \multicolumn{2}{c}{$\begin{array}{c}\text { Largest 10 Active } \\
\text { Managers }\end{array}$} \\
& Unweighted & Weighted & Unweighted & Weighted & Unweighted & Weighted \\
\hline 2012 & $3.9 \%$ & $3.8 \%$ & $13.7 \%$ & $14.4 \%$ & $10.2 \%$ & $11.3 \%$ \\
2013 & $2.4 \%$ & $2.3 \%$ & $11.5 \%$ & $12.3 \%$ & $11.2 \%$ & $11.9 \%$ \\
2014 & $3.7 \%$ & $3.4 \%$ & $9.2 \%$ & $9.9 \%$ & $8.1 \%$ & $8.8 \%$ \\
2015 & $2.4 \%$ & $2.1 \%$ & $6.3 \%$ & $6.8 \%$ & $7.2 \%$ & $7.3 \%$ \\
2016 & $2.8 \%$ & $2.4 \%$ & $7.8 \%$ & $8.4 \%$ & $8.7 \%$ & $8.7 \%$ \\
2017 & $4.0 \%$ & $3.8 \%$ & $7.7 \%$ & $7.9 \%$ & $8.9 \%$ & $8.5 \%$ \\
2018 & $2.5 \%$ & $2.3 \%$ & $6.9 \%$ & $7.6 \%$ & $9.4 \%$ & $8.9 \%$ \\
\hline Average & $3.1 \%$ & $2.9 \%$ & $9.0 \%$ & $9.6 \%$ & $9.1 \%$ & $9.4 \%$ \\
\hline \hline
\end{tabular}

Some of the commentators taking issue with our view and evaluating index fund stewardship more favorably argue that, among the thousands of votes that the Big Three cast each year at U.S. public companies, only a limited number of votes - and substantially less than 100 - are "potentially consequential" because they involve contested elections. ${ }^{161}$

Relatedly, a recent BlackRock release stresses that the vast majority of ballot items are not closely decided, ${ }^{162}$ and that say-on-pay votes are, in any event, not legally binding. ${ }^{163}$ In our view, however, Big Three say-on-pay voting matters. Companies pay close attention to say-on-pay votes and design their pay arrangements with an eye toward avoiding significant negative sayon-pay votes. ${ }^{164} \mathrm{Big}$ Three voting on say-on-pay is therefore a potentially

161. See, e.g., Kahan \& Rock, supra note 16, at 34 ("How many potentially consequential votes are there? It is a little hard to tell because of settlements before a proxy contest comes to a conclusion but the number is likely a two-digit figure (and likely in the low two-digits).").

162. See BlackRock, Proxy Voting Outcomes, supra note 115 ("The vast majority of ballot items are won or lost by margins greater than 30\%, meaning that even the three largest asset managers combined could not change the vote outcome.").

163. See id. ("[S]ay-on-pay is a mandatory, non-binding advisory vote ....").

164. See, e.g., Davis Polk \& Wardwell LLP, A Say-on-Pay Update-Plus Strategies for Responding to a Negative Recommendation by a Proxy Advisory Firm 1 (2018), https://www.davispolk.com/files/2018-11-29-a_say-on-pay_update_plus_strategies.pdf 
significant instrument for influencing and improving pay arrangements. Accordingly, nondeferential voting on say-on-pay resolutions could operate to improve pay arrangements and thereby produce significant benefits for index fund investors.

Our findings regarding voting decisions are consistent with those reported by four other current empirical studies. Three studies - one by Ryan Bubb and Emiliano Catan; another by Patrick Bolton, Tao Li, Enrichetta Ravina, and Howard Rosenthal; and a third by Davidson Heath, Daniele Macciocchi, Roni Michaely, and Matthew Ringgenberg-document that, in general, index funds tend to vote in a more pro-management way than other investment fund managers. ${ }^{165}$ Furthermore, a fourth study by Alon Brav, Wei Jiang, Tao Li, and James Pinnington finds that the votes of index funds are more pro-management than other investment managers in contested elections, another context in which vote outcomes are important for corporate managers. ${ }^{166}$ The results of these studies are all consistent with and reinforce the deference predictions of our incentive analysis.

\section{B. What the Big Three Do Not Do}

We now turn to discuss five types of stewardship activity that the Big Three generally do not undertake. The activities on which we focus are (i) monitoring business performance, (ii) influencing director identity; (iii) submission of shareholder proposals to facilitate changes favored by the index fund's own governance principles, (iv) contributing to corporate

[https://perma.cc/V7D9-K2KZ] ("[P]erforming poorly on a say-on-pay vote is not only disheartening, but can impact shareholder votes on election of directors[,] . . result in greater scrutiny of CEO performance, and require management and compensation committee members to expend significant time and resources to address concerns reflected by the vote.").

165. See Patrick Bolton, Tao Li, Enrichetta Ravina \& Howard Rosenthal, Investor Ideology 4 (European Corp. Governance Inst., Finance Working Paper No. 557/2018, 2019), https://ssrn.com/abstract=3119935 (on file with the Columbia Law Review) (characterizing the voting behavior of BlackRock and Vanguard as close to that reflected by management recommendations); Heath et al., supra note 129, at 12 (describing index funds as "more likely to cede authority to firm management"); Bubb \& Catan, supra note 129, at 3 (characterizing the voting behavior of the Big Three as "support[ing] management at much greater rates" than other investors).

166. Alon Brav, Wei Jiang, Tao Li \& James Pinnington, Picking Friends Before Picking (Proxy) Fights: How Mutual Fund Voting Shapes Proxy Contests 3 (European Corp. Governance Inst., Working Paper No. 601/2019, 2019), http://ssrn.com/abstract=3101473 [https://perma.cc/62QQ-RS52] [hereinafter Brav et al., Picking Friends] (describing "direct evidence that passive funds are significantly more 'pro-management' than active funds in proxy contests"). 
governance reforms by filing comments regarding SEC rulemaking and amicus briefs in precedential litigation, and (v) taking on lead plaintiff positions in consequential securities cases.

\section{Monitoring Business Performance}

Enhancing the financial returns of portfolio companies is an important objective for Big Three investors. Those investors would benefit from stewardship that identifies underperforming portfolio companies, analyzes changes that could improve their performance, and uses the substantial voting power of the Big Three to bring about such changes. ${ }^{167}$ In discussing his view that index funds offer "the best hope for corporate governance," Vanguard founder Jack Bogle stressed that "the new index fund rule is that if you don't like the management, fix the management because you can't sell the stock." 168 However, as we explain in this section, in the vast majority of companies in which a hedge fund activist is not agitating for change, the Big Three pay little attention to whether a company suffers from financial or business underperformance that might call for "fixing the management."169

Consider the important decisions that index funds make in the vast number of companies that hold uncontested elections in any given yearwhether to vote for the incumbent directors up for election, or to withhold votes. As we explained in section II.A.3, each of the Big Three's proxy voting guidelines makes the decision to withhold votes conditional entirely on certain specified divergences from governance principles. Importantly, our review of the Big Three's guidelines indicates that none of those guidelines list financial underperformance, no matter how severe or persistent, as a basis for withholding votes from directors.

Similarly, as we discussed in section II.A.2, the Big Three Stewardship Reports indicate that the Big Three's private, behind-the-scenes engagements - in those relatively infrequent cases in which they do occurfocus on addressing significant divergences from desirable governance principles. Importantly, these private engagements do not target or focus on

167. A study by Diane Del Guercio, Laura Seery, and Tracie Woidtke provides evidence that stewardship paying attention to underperformance could provide benefits, even if it would just lead to increased vote withholding from directors of companies that underperform. The study provides evidence, including "significant post-campaign operating performance improvements" and "a forced CEO turn-over rate of $25 \%$ in target firms in the 1 year following a campaign." Diane Del Guercio, Laura Seery \& Tracie Woidtke, Do Boards Pay Attention when Institutional Investor Activists "Just Vote No"?, 90 J. Fin. Econ. 84, 85 (2008).

168. See Benz, supra note 14.

169. The data sources and approach used in the empirical analyses in section II.B.1 are described in section B.1 of the Appendix. 
business underperformance. We reviewed all of the examples of behind-thescenes engagements described in the Big Three Stewardship Reports. We found zero cases where engagement was described as being motivated by financial underperformance. To be sure, some Big Three engagements follow interventions by activist hedge funds seeking to improve performance and focus on those interventions. ${ }^{170}$ However, even in those cases, the Big Three did not themselves identify underperformance but merely reacted to activist hedge funds doing so and proposing to address it.

Writers supportive of index fund stewardship seek to justify the Big Three's limited attention to financial underperformance by arguing that index fund managers "lack the expertise and the resources necessary to [identify and address firm-specific operational deficiencies] effectively." ${ }^{171}$ But because such arguments take such lack of "in-house expertise" as a given, they do not recognize that it is a product of the decisions made by index fund managers. Index fund managers have the resources to obtain or develop any in-house expertise that they might consider desirable.

Indeed, given the hundreds of companies in which the Big Three hold positions of $\$ 1$ billion or more, the interests of their beneficial investors could be well served by adding in-house personnel with financial expertise. Adding a sufficient number of such personnel could allow the Big Three to identify severe or persistent underperformance at particular portfolio companies. Once such underperformance is identified, those personnel could generate proposals for improving performance through changes in corporate leadership or strategy, and they could facilitate those changes using the Big Three's power and influence. Why then do the Big Three not employ such personnel on the significant scale that their holdings warrant? The lack of such personnel is consistent with, and can be explained by, the agency-costs view of index fund stewardship.

Some commentators taking issue with our view of index fund stewardship have argued that index fund managers do not need to pay attention to financial underperformance as they can count on activist hedge funds to bring such underperformance to the attention of other investors and

170. Vanguard, Annual Stewardship Report 2016-17, supra note 122, at 7.

171. Fisch et al., supra note 16 (manuscript at 20); see also Charles M. Nathan, Institutional Investor Engagement: One Size Does Not Fit All, The Conference Bd. (July 18, 2018), https://www.conference-board.org/blog/postdetail.cfm?post=6826 [https://perma.cc/3KLK-SQ9B] (explaining that the Big Three's stewardship teams "are principally focused on big picture environmental, social, and governance (ESG) issues ... [and] lack the skill-sets and manpower necessary to deal in depth with company specific issues of strategy design and implementation, capital allocation, M\&A opportunities, and operational and financial performance"). 
to initiate proposals for improving performance. ${ }^{172}$ The empirical evidence, however, indicates that companies often underperform for several years before an activist emerges to push for change. ${ }^{173}$ The interests of index fund investors are therefore not served by ignoring underperformance for long periods in the hope that an activist hedge fund may choose to address it sometime in the future.

Furthermore, as we discuss in section III.A.2(b), activist hedge funds have incentives to engage only when performance issues are very large and can be fixed quickly. The interests of index fund investors would be served by having other performance issues addressed as well. Thus, while the work of activist hedge funds often provides benefits to index fund investors, it cannot fully substitute for work that index fund managers could do themselves to address financial underperformance. Index fund managers largely avoid such work at the moment, even though it could provide index fund investors with significant additional benefits.

\section{Influencing Director Identity}

Directors matter. Their characteristics, background, and experience have considerable influence on the governance and performance of companies. The Big Three's governance principles impact the selection of directors, such as by discouraging the selection of directors who did not consistently attend past board meetings and encouraging gender diversity among directors. But among the very many potential directors who would comply with the Big Three's principles, some candidates would clearly be better choices than others given the particular portfolio company's circumstances and needs.

A board with governance processes that accord completely with the Big Three's standards may sometimes select one or more individuals who are not well suited to the company's needs, or do not select individuals likely to improve board performance. When the Big Three hold large stakes in such a company, their beneficial investors would be served by the index fund managers identifying when changes to the individuals on the board are desirable and facilitating those changes. Those changes might not require the index fund manager to be represented on the board-adding or removing one

172. For arguments that index funds rely on and interact with hedge funds that monitor companies, identify issues at those companies that would benefit from changes, and make proposals for such changes, see, for example, Fisch et al., supra note 16 (manuscript at 2729); Kahan \& Rock, supra note 16, at 5-6, 45.

173. For evidence that activist targets underperform significantly during the three years prior to the emergence of an activist hedge fund, see Lucian A. Bebchuk, Alon Brav \& Wei Jiang, The Long-Term Effects of Hedge Fund Activism, 115 Colum. L. Rev. 1085, 1123-30 (2015) [hereinafter Bebchuk et al., Hedge Fund Activism]. 
or more independent directors could be sufficient. ${ }^{174}$

In this section we therefore examine whether the Big Three do in fact seek to influence the selection of directors of their portfolio companies. ${ }^{175} \mathrm{We}$ examine both (i) formal nominations of directors, and (ii) less formal communications to portfolio companies suggesting that particular directors be added or removed. We find that the Big Three appear to avoid both types of activities.

We begin by gathering data on director nominations. Table 7 shows that there were approximately 3,800 director nominations at U.S. companies during the twelve-year period from 2007 through 2018. Our review of these nominations indicates that not a single nomination was made by any of the Big Three.

Table 7. Actual and Proposed Director Nominations

\begin{tabular}{cc|cc}
\hline \hline Year & Director Nominations & Year & Director Nominations \\
\hline 2007 & 360 & 2013 & 354 \\
2008 & 474 & 2014 & 349 \\
2009 & 332 & 2015 & 315 \\
2010 & 286 & 2016 & 282 \\
2011 & 250 & 2017 & 241 \\
2012 & 290 & 2018 & 259 \\
\hline
\end{tabular}

Total (2007-2018): 3,792

Even though the Big Three did not formally nominate any directors it is possible that they may have suggested that particular directors be added or removed. To evaluate whether this was the case we reviewed the examples of engagements described in their Stewardship Reports. Our review indicates that such communications were not part of any of the numerous engagements with named companies or examples of engagements with unnamed companies in the Stewardship Reports.

We examine this issue more systematically by gathering data on positions

174. For empirical evidence that a significant goal of activist hedge funds in negotiating settlement agreements with managers of activism targets is to introduce new independent directors into the boardroom, see Lucian A. Bebchuk, Alon Brav, Wei Jiang \& Thomas Keusch, Dancing with Activists, J. FIN. ECON. (forthcoming) (manuscript at 9-10, 20-25, 64), https://ssrn.com/abstract=2948869 (on file with the Columbia Law Review).

175. The data sources and approach used in the empirical analyses in section II.B.2, including the results reported in Tables 7 and 8, and the assumptions on which those analyses rely, are described in section B.2 of the Appendix. 
of $5 \%$ or more held by the Big Three during the twelve-year period from 2007 through 2018. As Table 8 indicates, the incidence of Big Three positions of $5 \%$ or more was large and increasing throughout the period, exceeding 2,000 in each year from 2009 and exceeding 4,000 each year from 2014.

Table 8 . Big Three Positions of 5\% or More

\begin{tabular}{lcccc}
\hline \hline & BlackRock & Vanguard & SSGA & Total \\
\hline 2007 & 1,233 & 106 & 62 & 1,401 \\
2008 & 1,666 & 158 & 91 & 1,915 \\
2009 & 1,882 & 241 & 57 & 2,180 \\
2010 & 1,916 & 432 & 68 & 2,416 \\
2011 & 1,869 & 819 & 98 & 2,786 \\
2012 & 1,926 & 1,302 & 142 & 3,370 \\
2013 & 2,082 & 1,419 & 150 & 3,651 \\
2014 & 2,156 & 1,721 & 186 & 4,063 \\
2015 & 2,158 & 1,842 & 132 & 4,132 \\
2016 & 2,250 & 1,903 & 197 & 4,350 \\
2017 & 2,250 & 1,994 & 203 & 4,447 \\
2018 & 2,367 & 2,051 & 183 & 4,601 \\
\hline \hline
\end{tabular}

As we discuss in section I.E, an index fund manager with a block of 5\% or more must file disclosure on Schedule 13D if its activities have the purpose or effect of influencing the identity of the individuals serving on the board. ${ }^{176}$ We therefore gathered data on Schedule 13D filings over the same period.

We find that neither Vanguard nor SSGA made a single Schedule 13D filing from 2007 through 2018. BlackRock made only nine Schedule 13D filings during this twelve-year period, during which it had an average of more than 1,000 positions of 5\% or more per year. And a majority of those filings (seven out of nine) were related to acquisitions by BlackRock of fund managers that had previously filed Schedule 13Ds, or going-private transactions that a BlackRock-affiliated private equity fund manager was party to.

This evidence supports our analysis in section I.E.3 concerning the Big

176. See 15 U.S.C. $\S 78 \mathrm{~m}$ (d) (2012) (requiring the filing of disclosure on Schedule 13D with the SEC); 17 C.F.R. $\S 240.13 d-1$ (a) (2019) (same). 
Three's incentives to avoid filing on Schedule 13D. ${ }^{177}$ Furthermore, this evidence indicates that the Big Three generally refrain from communications about particular individuals who they believe should be added to or removed from boards of directors in the vast number of cases where one or more of the Big Three had positions of 5\% or more in portfolio companies.

As with the argument discussed in section II.A.3 that the Big Three may not need to monitor financial performance because activist hedge funds do so, it could be argued that the Big Three generally do not need to engage with companies about adding or removing particular directors because activist hedge funds take on this role. ${ }^{178}$ But the Big Three's views on optimal board members likely differ from those of activist hedge funds. For example, SSGA has criticized portfolio companies that reach settlement agreements with activist hedge funds to add directors favored by activists without consulting other investors. ${ }^{179}$ The best way for the Big Three to increase the likelihood that underperforming companies would make director additions that are consistent with their views regarding value-maximization would be for a Big Three manager itself to communicate with its portfolio companies about the particular directors that it believes would be best for the company.

The Big Three's reluctance to be involved in selecting directors is difficult to reconcile with the value-maximization view. But it is consistent with, and can be explained by, our incentive analysis and the agency-costs view. Identifying directors who should be added or removed requires significant time and resources. Avoiding such actions is consistent with the Big Three's incentives to underinvest in stewardship, and with the limited resources they actually allocate to stewardship at particular portfolio companies. Furthermore, deference to corporate managers on the choice of directors (assuming general process requirements are met) is also consistent

177. Our findings in this section were reinforced by the subsequent finding reported by Heath et al., supra note 129, at 31-32, that index funds "are less likely to file Schedule 13D and more likely to file Schedule 13G." According to the evidence that we obtained, each of the Big Three is not merely "less likely" to file Schedule 13D, but in fact two of the Big Three completely avoided any such filing during the twelve-year period we examined, and one of the Big Three almost entirely avoided such filings during that period.

178. See, e.g., Fisch et al., supra note 16 (manuscript at 26) ("[I]ndividual fund complexes interact and rely upon ... activist hedge funds to supplement their voice, monitoring and information gathering processes.").

179. For an example of such criticism, see State St. Glob. Advisors, Protecting LongTerm Shareholder Interests in Activist Engagements 1 (2016), https://web.archive.org/web/20180430162941/https:/www.ssga.com/investmenttopics/environmental-social-governance/2016/Protecting-Long-Term-Shareholder-

Interests-in-Activist-Engagements.pdf (on file with the Columbia Law Review) (discussing "settlement agreements entered into rapidly between boards and activists and without the voice of long-term shareholders"). 
with the incentives for index fund managers to be excessively deferential to corporate managers that our agency-costs analysis identifies. ${ }^{180}$

\section{Eliminating Divergences from Governance Principles}

Supporters of index fund stewardship stress that index fund managers, and in particular the Big Three, have substantial advantages in bringing about similar governance improvements in a large number of firms, and that index fund stewardship is a natural fit for that objective. ${ }^{181}$ For example, Fisch, Hamdani, and Davidoff Solomon state that "the Big Three enjoy substantial economies of scale with respect to corporate governance and market-wide initiatives." "182 These authors also claim that contributing to similar governance improvements in many companies is something that the Big Three are both naturally well placed to do, and actually do. ${ }^{183}$

Similarly, Marcel Kahan and Edward Rock discuss the economies of scale advantages that the Big Three have with respect to "recurring governance issues," where they obtain "information in the course of their other votes ... that is material to a current vote they are asked to cast."184 These authors stress that, with respect to recurring governance issues, "the Big Three are likely to have incentives and information that is superior to those of advisors of actively managed funds" and "an inherent advantage" that comes from their larger size. ${ }^{185}$

As these commentators discuss, a main way in which the Big Three contribute to bringing about governance changes they favor is by voting in support of shareholder proposals calling for such changes. ${ }^{186}$ Under Rule 14a8, promulgated pursuant to the Securities Exchange Act of 1934, shareholders may submit proposals calling for governance changes to be voted on at the

180. See supra section I.E.

181. See, e.g., Appel et al., Passive Investors, Not Passive Owners, supra note 149, at 113 (stating that passive investors "might be effective at engaging in widespread, but lowcost, monitoring of firms' compliance with what they consider to be best governance practices").

182. Fisch et al., supra note 16 (manuscript at 15 ).

183. As the authors write, "[P] [corporate governance] provisions ... and to determine whether these provisions are likely, as a general matter, to increase or decrease firm value at the majority of portfolio companies. They are more likely to internalize any spillover effects that may arise from governance provisions." See id. (manuscript at 18).

184. Kahan \& Rock, supra note 16, at 44.

185. Id.

186. See, e.g., Fisch et al., supra note 16 (manuscript at 18) ("Voting on [issues raised by shareholder proposals] gives passive investors a powerful tool to pressure issuers for change ...."). 
company's annual meeting. ${ }^{187}$ Shareholder proposals advocating governance changes that receive majority support commonly lead to companies adopting those changes. ${ }^{188}$ As a result, when governance changes are widely viewed by investors as best practice, shareholder proposals advocating such changes have been very successful in bringing about those changes in companies that have not yet implemented them. For example, shareholder proposals have led a large number of public companies to eliminate staggered boards, remove supermajority provisions, and adopt majority voting-all governance arrangements that have received broad support from investors. ${ }^{189}$

However, as we explain below, while the Big Three have contributed to obtaining governance changes that their governance principles favor, by voting for shareholder proposals advocating such changes, they use their power to bring about these governance changes only in a limited way. ${ }^{190}$ In particular, because the Big Three have chosen not to put forward for a vote proposals advocating governance changes they favor, and merely vote on proposals submitted by others, they have forgone the potential for such changes in a large number of companies. ${ }^{191}$

187. 17 C.F.R. $\S 240.14 a-8$ (2019).

188. See Yonca Ertimur, Fabrizio Ferri \& Stephen R. Stubben, Board of Directors' Responsiveness to Shareholders: Evidence from Shareholder Proposals, 16 J. Corp. Fin. 53, 54, 62-64 (2010) (describing empirical evidence on the determinants of the likelihood of implementation of shareholder proposals).

189. See, e.g., id. at 54 (regarding majority voting); Emiliano M. Catan \& Michael Klausner, Board Declassification and Firm Value: Have Shareholders and Boards Really Destroyed Billions in Value? 2 (N.Y. Univ. Law \& Econ. Research Paper Series, Working Paper No. 17-39, 2017) (regarding declassification); Tara Bhandari, Peter Iliev \& Jonathan Kalodimos, Governance Changes Through Shareholder Initiatives: The Case of Proxy Access 1 (Feb. 18, 2019) (unpublished manuscript), https://ssrn.com/abstract=2635695 (on file with the Columbia Law Review) (regarding proxy access).

190. The data sources and approach used in the empirical analyses in section II.B.3, including the results reported in Table 9, are described in section B.3 of the Appendix.

191. In advancing their views that the Big Three perform well with respect to governance issues that recur in many situations, Fisch, Hamdani, and Davidoff Solomon cite to and rely on Appel, Gormley, and Keim. See, e.g., Fisch et al., supra note 16 (manuscript at 8) (citing Appel et al., Passive Investors, Not Passive Owners, supra note 149, among others, as preliminary evidence "that the effect of [passive investor stewardship] has been to improve both governance and performance"). The Appel, Gormley, and Keim study reported that increased holdings by index funds are associated with certain governance improvements, including greater board independence, removal of takeover defenses, and a lower likelihood of unequal voting rights. See Appel et al, Passive Investors, Not Passive Owners, supra note 149, at 114. Importantly, however, a full acceptance of the findings of Appel, Gormley, and

Keim in no way addresses the questions raised in this section about the choice of the Big Three not to advance governance changes they support by bringing shareholder proposals in a large number of portfolio companies that do not have these improvements. 
Table 9 reports data on shareholder proposals during the five-year period 2014-2018. As Table 9 indicates, during the five-year period from 2014 through 2018, approximately 1,500 shareholder proposals were submitted to companies in the Russell 3000 index, and more than 300 of those proposals received majority support. Table 9 also reports on the three types of proposals that received majority support most frequently: (i) proposals to declassify the board of directors, (ii) proposals to eliminate supermajority requirements to amend certain provisions of the company's charter or bylaws (or both), and (iii) proposals to require that receiving a majority of votes cast, rather than a plurality, be necessary for directors to be to elected. As Table 9 shows, there were approximately 50 successful proposals of each kind over the five-year period, and approximately 150 such successful proposals in total.

Appel, Gormley, and Keim find that increased holdings by index finds are associated with some reduction in the incidence of governance arrangements that the voting guidelines of the Big Three oppose. For example, they report that "[a] one standard deviation increase in ownership by passive funds is associated with a 3.5 percentage point increase in the likelihood of removing a poison pill and a 2.5 percentage point increase in the likelihood of reducing restrictions on shareholders' ability to call special meetings." Id. Because such eliminations of antitakeover defenses often result from the passage of shareholder proposals calling for such removal, and because the Big Three commonly vote for such removal, such an association is only to be expected. But our analysis in this section does not question that the strong governance preferences of the Big Three-as expressed through their votes on relevant shareholder proposals - have an effect. Rather, the main point of our analysis is to raise questions as to the extent to which the Big Three take actions to use their power to get their preferences implemented, and to bring about governance improvements on the large scale that their power and holdings would allow.

What we have explained is that, if the Big Three did not limit themselves to being merely reactive and supporting governance changes only in those situations in which other shareholders submit shareholder proposals, and if they instead took an active role, they would be able to bring about the changes that their own voting guidelines view as desirable at many, or most, of the public companies in their portfolios that currently do not have the arrangements they favor. The results reported by Appel, Gormley, and Keim are consistent with, and do not question, the importance of this question.

Finally, we note that the commentators relying on the Appel, Gormley, and Keim study do not engage with subsequent empirical work that reports findings that increased holdings by index funds is associated with certain negative governance effects. See Cornelius Schmidt \& Rüdiger Fahlenbrach, Do Exogenous Changes in Passive Institutional Ownership Affect Corporate Governance and Firm Value?, 124 J. FIN. ECON. 285, 293-94 (2017) (finding that increases in passive ownership increase the likelihood that a CEO becomes chairman or president and that fewer new independent directors will be appointed). 
Table 9. Submission of Shareholder Proposals

\begin{tabular}{cccccc}
\hline \hline Year & $\begin{array}{c}\text { Shareholder } \\
\text { Proposals }\end{array}$ & \multicolumn{5}{c}{ Shareholder Proposals Receiving Majority Support } \\
All & Proposals & $\begin{array}{c}\text { Declassify } \\
\text { Board of } \\
\text { Directors }\end{array}$ & $\begin{array}{c}\text { Eliminate } \\
\text { Supermajority } \\
\text { Requirements }\end{array}$ & $\begin{array}{c}\text { Require } \\
\text { Majority } \\
\text { Voting }\end{array}$ \\
\hline 2014 & 289 & 64 & 16 & 7 & 14 \\
2015 & 377 & 105 & 13 & 8 & 8 \\
2016 & 302 & 80 & 5 & 10 & 17 \\
2017 & 245 & 55 & 5 & 13 & 9 \\
2018 & 285 & 39 & 7 & 9 & 3 \\
\hline Total & 1,498 & 343 & 46 & 47 & 51 \\
\hline \hline
\end{tabular}

The Big Three's voting guidelines express broad support for proposals to introduce annual elections, eliminate supermajority requirements, or adopt majority voting. ${ }^{192}$ Consistent with these guidelines, our review indicates that BlackRock and SSGA voted in favor of a majority of the proposals in each category each year during the five-year period we consider, and Vanguard voted in favor of a majority of proposals to introduce annual elections each year during that period and a majority of proposals to adopt majority voting from 2015 through 2018.

However, while the Big Three have been very active in supporting proposals advocating governance changes favored by their governance principles, they have completely refrained from initiating such proposals. Our review of the approximately 1,500 shareholder proposals submitted during the examined five-year period did not identify a single proposal submitted by any of the Big Three. To be sure, it is unsurprising that none of the Big Three submitted any proposals in the categories that they generally do not support. The issue we raise, however, is that each of the Big Three also chose not to submit any proposals of the type that they generally do support. ${ }^{193}$

192. For examples of proxy voting guidelines supporting such proposals, see BlackRock, Proxy Voting Guidelines, supra note 157, at 2-6; State St. Glob. Advisors, Proxy Voting and Engagement Guidelines 2019, supra note 110; Vanguard, Proxy Voting Guidelines, supra note 110 , at $16-17$.

193. Consistent with the evidence we provide, a BlackRock release notes that "we have never filed a shareholder proposal on any company's proxy statement." BlackRock, Stewardship Ecosystem, supra note 28, at 10. But BlackRock does not explain how the interests of investors in its funds are served by its choice not to file shareholder proposals, even when companies have been persistently unresponsive to BlackRock's communications over a long period. 
We would like to discuss an argument that might be made in an attempt to "justify" and reconcile the Big Three's avoidance of shareholder proposal submissions reflecting their governance principles with the valuemaximization view. First, it might be argued that the Big Three have no need to submit shareholder proposals because all the proposals that would serve the interests of their beneficial investors are already being submitted by others. But many shareholder proponents have much more limited resources than the Big Three. As a result, many proposals that the Big Three would support are not submitted at all, or are submitted only after a delay of many years.

In particular, a large proportion of the Big Three's portfolio companies have classified boards rather than annual elections, supermajority rather than regular majority requirements to amend charters and bylaws, and plurality voting rather than majority voting. As of June 30, 2019, 1,157 companies in the Russell 3000 (39\% of Russell 3000 companies) had classified boards; $1,681(56 \%)$ companies required a supermajority to amend certain provisions of the charter or bylaws (or both); and 1,440 (48\%) companies had plurality voting, rather than majority voting.

Annual elections, regular majorities for charter and bylaw amendments, and majority voting are all arrangements called for by the Big Three's voting guidelines. ${ }^{194}$ But the great majority of those portfolio companies have yet to receive shareholder proposals calling for such arrangements. Submission of proposals advocating these changes by any of the Big Three would likely have led to the adoption of such changes by many companies. Given the Big Three's focus on governance arrangements in general, their support for these arrangements in particular, and the effectiveness of shareholder proposals in obtaining such arrangements, it would be natural to expect the Big Three to make extensive use of shareholder proposals at those companies. ${ }^{195}$

By refraining from submitting shareholder proposals, the Big Three enable many portfolio companies to maintain governance arrangements that are inconsistent with the Big Three's governance principles. As a result,

194. See supra note 192 and accompanying text.

195. In discussing how shareholder proposals can bring about improvement in governance arrangements, Fisch, Hamdani, and Davidoff Solomon note that "issuers are responsive to the interests of large investors and will frequently modify their policies rather than putting issues to a vote that they expect to lose." Fisch et al., supra note 16 (manuscript at 19) (citing Rob Bauer, Frank Moers \& Michael Viehs, Who Withdraws Shareholder Proposals and Does It Matter? An Analysis of Sponsor Identity and Pay Practices, 23 Corp. Governance 472 (2015)). Fisch, Hamdani, and Davidoff Solomon are correct that submission of shareholder proposals sometimes brings about governance improvements without the need for the proposal to go to vote. But they do not engage with the evidence that the Big Three do not submit any shareholder proposals, and therefore do not lead companies to reach settlements that would avoid votes. 
consistent with the agency-costs view, the Big Three's stewardship activities serve their beneficial investors significantly less than they could. Thus, the Big Three's practice of voting consistently for shareholder proposals advocating certain changes yet never initiating such proposals is difficult to reconcile with the value-maximization view.

This reactive-only approach, however, is both consistent with and can be explained by the agency-costs view. Whereas corporate managers have come to expect and accept the Big Three voting reactively for shareholder proposals advocating changes consistent with governance best practices, corporate managers might view the proactive submission of proposals as adversarial or even confrontational. Although a reactive-only approach to shareholder proposals does not serve the interests of the Big Three's beneficial investors, it is consistent with the deference incentives that we have identified.

\section{Contributing to Corporate Governance Legal Reforms}

The Big Three's beneficial investors would benefit from having their index fund managers contribute to corporate governance reforms that are likely to have a material effect on their portfolio companies. The Big Three could serve their investors' interests by either facilitating desirable rule changes or impeding undesirable changes. Commentators have long observed that index fund investors have an especially keen interest in rule changes that could enhance the value of a large number of companies, even by a small amount. $^{196}$

Supporters of index fund stewardship argue that index fund managers have substantial advantages over other kinds of investors in bringing about similar governance improvements in a large number of firms. This view also implies that index fund stewardship would include facilitating legal reforms that would apply to a large number of companies. ${ }^{197}$ Indeed, given the Big Three's focus on governance practices, supporters of index fund stewardship have argued that the Big Three are well positioned to contribute in this way. ${ }^{198}$ For instance, Fisch, Hamdani, and Davidoff Solomon argue that "[p]assive

196. See, e.g., Ronald J. Gilson \& Reinier Kraakman, Reinventing the Outside Director: An Agenda for Institutional Investors, 43 Stan. L. Rev. 863, 867 (1991) ("[I]ndexed institutional investor[s] should seek a corporate governance system that . . can improve the performance of all companies.").

197. See supra notes 181-185 and accompanying text.

198. For such arguments by supporters of index fund stewardship, see,for example, Eckstein, supra note 133 (manuscript at 30-38) (arguing that the broad ownership of the Big Three gives them incentives to address "macro-legal risks" that apply to significant numbers of their portfolio companies); Fisch et al., supra note 16 (manuscript at 29-30) (discussing index fund managers' active influence on regulatory policy). 
investors regularly comment upon and call for change to the rules adopted by the SEC under the federal securities laws." ${ }^{199}$ Yet these commentators do not provide any empirical evidence in their study, and they do not engage with the empirical evidence provided in this section that the Big Three's participation in the comment process is, in fact, very limited.

In this section we provide empirical evidence about two key ways in which institutional investors can seek to influence legal rules regarding public companies: by commenting on SEC proposed rules regarding corporate governance, and by filing amicus curiae briefs in significant precedential litigation in this field. ${ }^{200}$ We find that the Big Three have participated very little in either of these activities. Instead, our analysis reveals a pattern of the Big Three systematically staying on the sidelines on those decisions and generally avoiding expressing any position or preference with respect to the SEC proposals and judicial decisions that we consider. We explain that systematically staying on the sidelines does not serve the interests of index fund investors but is consistent with the private incentives of index fund managers.

(a) SEC Comment Letters. By submitting comments on proposed SEC rules, commenters can influence SEC rulemaking. Under the valuemaximization view, since the Big Three hold more than $20 \%$ of the equity in large corporations, ${ }^{201}$ they should be expected to frequently express their views on proposed SEC rules. Clearly, when a Big Three manager views a proposed SEC rule as desirable or undesirable, submitting a comment would help increase the value of portfolio companies, or avoid value decreases. Furthermore, even if the index fund manager viewed a proposed rule as practically insignificant for investor interests, expressing this view could still benefit the manager's beneficial investors by directing the SEC's limited resources and attention to changes with greater potential to benefit investors.

We hand-collected from the SEC website all comments on SEC proposed rules regarding corporate governance during the twenty-four-year period from 1995 through 2018. We found 80 proposed rules regarding corporate governance during this period, and we reviewed all comments submitted in relation to each of these rules. As Table 10 indicates, each of the Big Three submitted comments on only one or two of the twenty proposed rules that attracted the most comments. By comparison, the two largest asset owners,

199. Fisch et al., supra note 16 (manuscript at 29).

200. The data sources and approach used in the empirical analyses in section II.B.4, including the results reported in Tables 10 and 11, and the assumptions on which those analyses rely, are described in section B.4 of the Appendix.

201. See Bebchuk \& Hirst, Specter of the Giant Three, supra note 3, at 733-34 (presenting evidence that the Big Three held $20.5 \%$ of the equity of S\&P 500 companies in 2017). 
CalPERS and CalSTRS — whose assets are largely indexed but are very small compared to those managed by the Big Three-submitted comments on twelve and seven proposed rules, respectively. ${ }^{202}$ A similar picture emerges when we examine the larger set of proposed rules that received relatively less attention. Of those sixty proposed rules, each of the Big Three submitted comments with respect to no more than four rules (less than 10\%). In contrast, CalPERS and CalSTRS submitted comments with respect to nine and eight rules, respectively. ${ }^{203}$

202. We also conducted the analysis in Table 10 for the second half of the period covered by Table 10, that is, for the 12-year period from 2007 through 2018. During this period, the Big Three and the largest two asset owners submitted more comments than in the first half of the 1995-2018 period. However it remains the case that each of the Big Three had a low incidence of comment submission; that incidence was also considerably lower than the incidence of comment submission for each of the largest two asset owners. For example, from 2007 through 2018, each of the Big Three submitted comments on between $11 \%$ and $22 \%$ of the proposed rules in the top $25 \%$ by comments received, and $4 \%$ of the proposed rules in the lower $75 \%$ by comments received. In contrast, the largest two asset owners submitted comments on between $44 \%$ and $67 \%$ of the proposed rules in the top $25 \%$ by comments received, and between $25 \%$ and $50 \%$ of the proposed rules in the lower $75 \%$ by comments received.

For the purpose of the analysis described in this footnote, we considered proposed rules with multiple requests for comment to have been proposed in the year in which the rule was first proposed.

203. Some commentators who view index fund stewardship favorably have noted that index fund managers conduct meetings with regulators. See Eckstein, supra note 134, (manuscript at 45) (same); Fisch et al., supra note 16, at 30 (discussing such meetings). The SEC website discloses all meetings held by SEC personnel with respect to proposed rules. We collected data from the website about meetings that the Big Three and the largest asset owners conduct with the SEC regarding the universe of proposed rules considered in Table 10. The Big Three conducted a total of 5 meetings with the SEC, regarding 2 proposed rules, all of which were in the most commented $25 \%$ of rules: BlackRock conducted no meetings, Vanguard conducted 3 total meetings on 2 proposals, and SSGA conducted 2 meetings on a single proposal. In contrast, the two largest asset owners conducted 14 meetings with the SEC, regarding 6 different proposed rules.

Considering how many SEC proposed rules the Big Three engaged with in any wayeither commenting or meeting with the SEC - increases their incidence of engagement with proposed rules slightly but does not qualitatively change the results reported in Table 10; that incidence remains low and considerably below that of the two largest asset managers. In particular, when both comments and meetings are considered, out of the 20 proposed rules that attracted highest number of comments, BlackRock engaged with 1 proposed rule, Vanguard 3, and SSGA 3. Furthermore, because none of the Big Three conducted meetings with respect to the proposed rules in less commented $75 \%$ of proposed rules, including meetings in the analysis does not change any of the figures in Table 10 that relate to those proposed rules. 
Table 10. Involvement in SEC Proposed Rules

Regarding Corporate Governance

\begin{tabular}{|c|c|c|c|c|c|c|c|}
\hline \multirow{3}{*}{$\begin{array}{l}\text { Most Commented 25 } \\
\text { of Proposed Rules }\end{array}$} & \multicolumn{4}{|c|}{ Index Fund Managers } & \multicolumn{3}{|c|}{ Asset Owners } \\
\hline & BlackRock & Vanguard & SSGA & Total & \multicolumn{2}{|c|}{ CalPERS CalSTRS } & \multirow[t]{2}{*}{ Total } \\
\hline & & & & & & & \\
\hline Comments & 1 & 3 & 2 & 6 & 19 & 16 & 33 \\
\hline $\begin{array}{l}\text { Comments per } \\
\text { Proposed Rule }\end{array}$ & 0.05 & 0.15 & 0.10 & 0.30 & 0.95 & 0.80 & 1.70 \\
\hline $\begin{array}{l}\text { Proposed Rules } \\
\text { Commented On }\end{array}$ & 1 & 2 & 2 & 5 & 12 & 7 & 12 \\
\hline $\begin{array}{l}\text { Proportion of } \\
\text { Proposed Rules } \\
\text { Commented On }\end{array}$ & $5 \%$ & $10 \%$ & $10 \%$ & $25 \%$ & $60 \%$ & $35 \%$ & $60 \%$ \\
\hline $\begin{array}{l}\text { Remaining } 75 \% \text { of } \\
\text { Proposed Rules } 60\end{array}$ & & & & & & & \\
\hline Comments & 1 & 3 & 1 & 5 & 14 & 9 & 23 \\
\hline $\begin{array}{l}\text { Comments per } \\
\text { Proposed Rule }\end{array}$ & 0.02 & 0.05 & 0.02 & 0.08 & 0.23 & 0.15 & 0.37 \\
\hline $\begin{array}{l}\text { Proposed Rules } \\
\text { Commented On }\end{array}$ & 1 & 3 & 1 & 5 & 14 & 9 & 15 \\
\hline $\begin{array}{l}\text { Proportion of } \\
\text { Proposed Rules } \\
\text { Commented On }\end{array}$ & $2 \%$ & $5 \%$ & $2 \%$ & $8 \%$ & $23 \%$ & $15 \%$ & $25 \%$ \\
\hline
\end{tabular}

It could be argued that another explanation for our findings is that the Big Three consider filing comments with the SEC to be a futile exercise, since they may expect them to have little effect on the SEC's decisions. ${ }^{204}$ Following this view, the submission of a large number of comments by others, rather than the infrequent submission of comments by the Big Three, should be viewed as surprising. But the SEC releases issued following comment processes often cite and discuss submitted comments, ${ }^{205}$ and there

204. We are grateful to Stephen Davidoff Solomon and Stephen Fraidin for stressing the usefulness of considering this objection.

205. To illustrate, the SEC's final rule regarding Pay Ratio Disclosure referred to 250 different comment letters and its final rule regarding Conflict Minerals referred to 247 different comments. Pay Ratio Disclosure, Exchange Act Release No. 33-9877, 80 Fed. Reg. 50,103 (Aug. 18, 2015); Conflict Minerals, Exchange Act Release No. 34-67716, 77 Fed. Reg. 56,273 (Sept. 12, 2012). 
is little reason to view the submission of comments by many profit-making players (such as public companies) as irrational or wasteful.

Moreover, and importantly, even if we were to accept that the average comment submitted by investors should be expected to have no effect on SEC decisions, it would be unlikely that a comment filed by one of the Big Three would have the same lack of effect. Instead, if one or more Big Three managers took a clear position on a proposed SEC rule, the trillions of dollars of their equity investments, and the breadth of their investments across all significant U.S. public companies, would likely give substantial weight to their comment and cause the SEC to give it significant attention.

We note that four of the six final SEC rules that resulted from the 25 most-commented rule proposals cited comments by the Big Three. For instance, the SEC's final rule in 2010 regarding proxy access, Facilitating Shareholder Director Nominations, referenced Vanguard's comment letter 16 times, ${ }^{206}$ and the SEC's Amendments to Regulation SHO in 2009 referred to two comment letters from Vanguard a total of twelve times. ${ }^{207}$ Views expressed by the Big Three on corporate governance matters also often attract substantial attention and commentary from prominent advisory firms, the media, and other institutional investors. ${ }^{208}$ Thus, the common tendency of the Big Three to stay on the sidelines and avoid filing SEC comments stating their position is unlikely to be explained by a general expectation that doing so could be expected to have no effect on SEC decisionmaking.

(b) Amicus Curiae Briefs in Precedential Litigation. Supporters of index fund stewardship have claimed that "[i]nstitutional investors now regularly file amicus briefs." ${ }^{209}$ We therefore examine the submission of amicus briefs in cases important for protecting and enhancing the value of index fund portfolios.

Table 11 presents data from 2008 through 2017 on the ten cases of

206. Facilitating Shareholder Director Nominations, Exchange Act Release No. 339136, 75 Fed. Reg. 56,668 (Sept. 16, 2010).

207. Amendments to Regulation SHO, 75 Fed. Reg. 11232, 11238, 11246, 11248, 11251, 11272, 11292-94, 11313 (Mar. 10, 2010) (codified at 17 C.F.R. pt. 242 (2019)). In addition, the SEC's final rule, Strengthening the Commission's Requirements Regarding Auditor Independence, 68 Fed. Reg. 6006, 6020, 6029 (Feb. 5, 2003) (codified at 17 C.F.R. pts. 210, 240, 249, 274), referred to Vanguard's comment letter five times, and the SEC's Securities Offering Reform, 70 Fed. Reg. 44,722, 44,745, 44,767 (Aug. 3, 2005) (codified at 17 C.F.R. pts. 200, 228, 229, 230, 239, 240, 243, 249, 274), referred to SSGA's comment letter twice.

208. See, e.g., supra note 117 and accompanying text (detailing examples of prominent law firms and media reports referring to changes in the corporate governance policies of the Big Three).

209. See Fisch et al., supra note 16 (manuscript at $30 \&$ n.191) (citing a blog post as "reporting that BlackRock signed an amicus brief to the U.S. Supreme Court arguing for marriage equality for same sex couples"). 
precedential litigation regarding investor protection that the Council of Institutional Investors identified as sufficiently important to warrant the filing of an amicus brief. ${ }^{210}$ We reviewed the filings in each of these cases to identify all of the briefs submitted. Eight of the ten cases gathered a significant number of amicus curiae briefs, with five of the ten drawing more than 10 briefs each. Consistent with the possibility that amicus briefs could have an influence, our review indicated that seven of the ten judicial decisions cited amicus briefs, with five of those ten decisions citing more than one amicus brief each.

Reviewing the filed briefs, we find that the two largest asset owners, CalPERS and CalSTRS, filed their own briefs or joined the Council of Institutional Investors' brief in four of the ten cases. Their assets are largely indexed, although in each case less than $5 \%$ of the assets under management were held by BlackRock. But our review of the filings indicated that none of the Big Three filed a single amicus curiae brief in any of the ten cases of precedential litigation that we consider. In these cases, the voices of the Big Three, which represent more than $20 \%$ of corporate equities, were not heard.

210. We are grateful to the General Counsel of the Council of Institutional Investors (CII) for providing us with this list. We did not include CII amicus briefs submitted in cases that were not related to corporate governance, such as a case relating to stock market regulation, or an amicus brief in support of a petition for certiorari that was denied. These exclusions did not affect our results as none of the Big Three submitted amicus briefs in any of these cases. 
Table 11. Amicus Curiae Briefs, 2007-2018

\begin{tabular}{|c|c|c|}
\hline Case & $\begin{array}{l}\text { Amicus } \\
\text { Briefs }\end{array}$ & $\begin{array}{c}\text { Briefs by } \\
\text { Two Largest } \\
\text { Asset Owners }\end{array}$ \\
\hline $\begin{array}{l}\text { Stoneridge Investment Partners, LLC v. Scientific-Atlanta, } \\
\text { Inc., } 552 \text { U.S. } 148 \text { (2008) }\end{array}$ & 31 & $\checkmark \checkmark$ \\
\hline $\begin{array}{l}\text { Free Enterprise Fund v. Public Co. Accounting Oversight } \\
\text { Board, } 537 \text { F.3d } 667 \text { (D.C. Cir. 2008) }\end{array}$ & 4 & \\
\hline $\begin{array}{l}\text { Free Enterprise Fund v. Public Co. Accounting Oversight } \\
\text { Board, } 561 \text { U.S. } 477 \text { (2010) }\end{array}$ & 17 & $* *$ \\
\hline Merck \& Co. v. Richard Reynold, 559 U.S. 633 (2010) & 15 & \\
\hline $\begin{array}{l}\text { New York State Teachers' Retirement System v. The Mercury } \\
\text { Pension Fund Group, } 618 \text { F.3d } 988 \text { (9th Cir. 2010) }\end{array}$ & 1 & \\
\hline $\begin{array}{l}\text { Janus Capital Group, Inc. v. First Derivative Traders, } 564 \\
\text { U.S. } 135 \text { (2011) }\end{array}$ & 13 & \\
\hline Business Roundtable v. SEC, 647 F.3d 1144 (D.C. Cir. 2011) & 6 & $* *$ \\
\hline $\begin{array}{l}\text { New Jersey Carpenters Health Fund v. RALI Series 2006- } \\
\text { QO1 Trust, } 477 \text { F. App'x. } 809 \text { (2d Cir. 2012) }\end{array}$ & 6 & \\
\hline $\begin{array}{l}\text { Halliburton Co. v. Erica P. John Fund, Inc., } 573 \text { U.S. } 258 \\
\text { (2014) }\end{array}$ & 26 & $* *$ \\
\hline $\begin{array}{l}\text { Corre Opportunities Fund, LP v. Emmis Communications } \\
\text { Corp., } 792 \text { F.3d } 737 \text { (7th Cir. 2015) }\end{array}$ & 3 & \\
\hline
\end{tabular}

$\checkmark \checkmark$ Briefs filed separately by both of the asset owners ** Brief filed by both of the asset owners, jointly with CII

Although supporters of index fund stewardship have argued that the Big Three are well positioned to contribute to legal reforms affecting a large number of public companies, the evidence discussed above indicates that their activities in this regard are very modest. Indeed, the Big Three have collectively contributed fewer comments on SEC proposed rules regarding corporate governance, and fewer amicus briefs in precedential litigation, than the two largest asset owners, which have corporate equities with an aggregate value that is less than $5 \%$ of the assets under management of BlackRock or 


\section{Vanguard. $^{211}$}

Under the value-maximization view, more involvement should be expected from investors that collectively hold more than $\$ 5$ trillion in corporate equities. But the reluctance of the Big Three to contribute to corporate governance reforms is consistent with, and can be explained by, the incentives identified by the agency-costs view described in section I.C. The incentives of the Big Three to defer to corporate managers discourage them from supporting reforms that strengthen shareholder rights. At the same time, the Big Three's interest in reducing the salience of their deference gives them incentives not to oppose such reforms. Thus, the interests of the Big Three are likely served by generally staying on the sidelines and not lending their influential support either in favor of or against such reforms.

\section{Involvement in Securities Litigation}

Securities litigation provides an important instrument for deterring misconduct by corporate insiders, and for compensating investors if such misconduct occurs. The "lead plaintiff" that is selected in any securities class action plays a significant role in navigating the litigation. The lead plaintiff chooses class counsel, sets the terms of engagement with class counsel, and oversees the terms of any settlement, including monetary recovery and prospective corporate governance changes required as part of the settlement.

Since the adoption of the Private Securities Litigation Reform Act (PSLRA) in 1995, securities law has followed a presumption that the plaintiff with the largest financial interest in a class action should be the lead plaintiff. $^{212}$ This reflects a view that it is advantageous for investors to have an institutional investor with significant "skin in the game" to play the role of lead plaintiff, because such investors have the greatest incentive and ability to monitor the litigation and ensure that it is conducted in the interest of investors. $^{213}$

211. As of June 30, 2018, CalPERS held U.S. equities with an aggregate market value of $\$ 84.7$ billion, and CalSTRS held U.S. equities with an aggregate market value of $\$ 65.0$ billion. See Cal. Pub. Emps.' Ret. Sys., 2017-2018 Annual Investment Report, 206 (2018), https://www.calpers.ca.gov/docs/forms-publications/annual-investment-report-2018.pdf [https://perma.cc/N8RQ-XXPD]; Cal. State Teachers' Ret. Sys., Comprehensive Annual

Financial Report 117 (2018), https:/www.calstrs.com/sites/main/files/fileattachments/cafr2018.pdf?1546017967 [https://perma.cc/9YQE-TAUT] (listing a global equity portfolio of $\$ 120.3$ billion, of which 54\% was held in U.S. equities).

212. Private Securities Litigation Reform Act of 1995, 15 U.S.C. $\S 78 u-4(a)(3)(B)(i i i)$ (2012).

213. For an influential article written during the debate leading to the passage of the PSLRA that advocated having institutional investors serve as lead plaintiffs, see Elliott J. Weiss \& John S. Beckerman, Let the Money Do the Monitoring: How Institutional Investors 
With over $\$ 5$ trillion in corporate equities, the Big Three's beneficial investors have significant monetary interests in the outcome of many securities class actions. The legal rules and policies of the PSLRA suggest that the interests of these investors are best served by having the Big Threeinstitutional investors with very substantial skin in the game-play the role of lead plaintiffs in significant securities class actions. As lead plaintiffs the Big Three could help to ensure that the outcome of those actions would best serve investors. Among other things, they could ensure that class counsel has appropriate incentives and that corporate governance reforms are part of any settlement where they are necessary. ${ }^{214}$ However, as we show below, the Big Three have also chosen to "stay on the sidelines" with respect to the leadership of securities litigation.

To identify the decisions made by the Big Three in this area, we examine the extent to which the Big Three served as lead plaintiffs in significant securities cases during the twelve-year period from 2007 through $2018 .^{215}$ Table 12 presents data that we gathered regarding the incidence of securities class actions over that period. To avoid marginal cases that are more likely to be frivolous we focus on cases settled for more than $\$ 10$ million, and the subset of those cases settled for more than $\$ 100$ million. These cases can be expected to be brought regardless of who serves as lead plaintiff. As they are likely to take place in any event, there are significant benefits for investors from having the litigation overseen by a lead plaintiff with substantial skin in the game. Table 12 shows that more than 400 class actions settled for more than $\$ 10$ million from 2007 through 2018, with total recovery of over $\$ 40$ billion. Of these cases, 90 settled for more than $\$ 100$ million each, with total recovery of over $\$ 30$ billion.

Can Reduce Agency Costs in Securities Class Actions, 104 Yale L.J. 2053, 2121 (1995) ("[I]nstitutional investors could realize substantial benefits by serving as lead plaintiffs in class actions.").

214. One commentator responded to our analysis in this section by arguing that there are legal complexities, grounded in the difference between the characteristics of index funds and those of other investors, which might preclude index funds from obtaining a lead plaintiff position even when they have a large stake. See Alexander I. Platt, Index Fund Enforcement, 53 U.C. Davis L. Rev. (forthcoming) (manuscript at 40-41), https://corpgov.law.harvard.edu/wp-content/uploads/2019/11/Alexander-Platt.pdf

[https://perma.cc/7KKZ-YGLZ]. But in some well-known cases, public pension funds have served as lead plaintiffs, even though - as John Coates explains - the equity portfolios of many public pension funds are largely based on portfolios that are passively managed based on broad indexes. See Coates, supra note 16, at 10-11. For an example of a class action led by CalPERS, see In re UnitedHealth Group Inc. PSLRA Litig., 643 F. Supp. 2d 1094 (D. Minn. 2019). Furthermore, Platt does not cite any cases in which courts have turned down requests to appoint one of Big Three as lead plaintiffs.

215. The data sources and approach used in the empirical analyses in section II.B.5, including the results reported in Table 12, and the assumptions on which those analyses rely, are described in section B.5 of the Appendix. 
Table 12. Securities Class Action Cases

\begin{tabular}{ccccc}
\hline \hline Year & $\begin{array}{l}\text { Cases Settled for } \\
\text { over } \$ 10 m\end{array}$ & $\begin{array}{l}\text { Total Recovery in } \\
\text { Cases Settled for } \\
\text { over } \$ 10 m(\$ m)\end{array}$ & $\begin{array}{l}\text { Cases Settled } \\
\text { for over } \$ 100 m\end{array}$ & $\begin{array}{l}\text { Total Recovery } \\
\text { in Cases Settled } \\
\text { for over } \$ 100 m \\
(\$ m)\end{array}$ \\
\hline 2007 & 39 & $\$ 6,507$ & 9 & $\$ 5,501$ \\
2008 & 35 & $\$ 1,896$ & 5 & $\$ 922$ \\
2009 & 42 & $\$ 4,451$ & 10 & $\$ 3,656$ \\
2010 & 39 & $\$ 2,013$ & 6 & $\$ 950$ \\
2011 & 29 & $\$ 2,813$ & 6 & $\$ 1,910$ \\
2012 & 29 & $\$ 2,816$ & 8 & $\$ 1,939$ \\
2013 & 34 & $\$ 5,822$ & 9 & $\$ 5,000$ \\
2014 & 30 & $\$ 1,776$ & 4 & $\$ 940$ \\
2015 & 34 & $\$ 4,654$ & 12 & $\$ 3,993$ \\
2016 & 39 & $\$ 4,692$ & 13 & $\$ 3,793$ \\
2017 & 30 & $\$ 1,409$ & 3 & $\$ 527$ \\
2018 & 28 & $\$ 4,485$ & 5 & $\$ 3,695$ \\
\hline Total & 408 & $\$ 43,335$ & 90 & $\$ 32,827$ \\
\hline \hline
\end{tabular}

For the reasons discussed above, the Big Three's beneficial investors could well have benefited from having their fund managers serve as lead plaintiff in some of these significant securities class actions. But our review of the data indicates that none of the Big Three served as lead plaintiff in any of these securities class actions during the twelve-year period that we examined. ${ }^{216}$

216. Responding to our analysis in this section, Alexander Platt argues that, although the Big Three have indeed avoided taking any lead plaintiff positions, they have in some cases taken direct action, or opted out of class action litigation and pursued claims against defendants separately. See Platt, supra note 214 (manuscript at 41-43). However, Platt notes only a handful of cases in which such direct actions or opt-outs took place, and an empirical study cited by Platt reports that, out of the 1,458 securities litigation cases reviewed between 1996 and 2014, only twenty cases involved opt-outs by "other institutional investors," in which broad category the study included mutual funds, hedge funds, and other investment companies. See id. (manuscript at 17 n.100) (citing Amir Rozen, Brendan Rudolph \& Christopher Harris, Opt-Out Cases in Securities Class Action Settlements: 2012-2014 Update 3 (2016)). Likely many fewer than twenty of these cases involved opt-outs by any of 
The avoidance of any lead plaintiff positions by the Big Three is in tension with the value-maximization view. ${ }^{217}$ But this pattern is consistent with, and can be explained by, the agency-costs view and its incentive analysis. ${ }^{218}$ First, the empirical pattern is consistent with the incentive to underinvest in stewardship. ${ }^{219}$ If an index fund manager serving as lead plaintiff in a significant class action would increase portfolio value by $\$ 1$ million, doing so is efficient if the marginal investment in stewardship required is less than $\$ 1$ million. However, if the index fund manager has a fractional share of $1 \%$, serving as lead plaintiff position is not in the manager's interests if the additional marginal stewardship investment required would exceed $\$ 10,000$.

Similarly, the avoidance of any lead plaintiff positions is also consistent with the Big Three's deference incentives. ${ }^{220}$ Being an effective lead plaintiff may require taking strong positions against certain corporate managers, which corporate managers may view unfavorably. At the same time, because decisions made in securities class actions are public, lead plaintiffs' decisions can be scrutinized. For a Big Three lead plaintiff to be excessively deferential toward corporate managers would make that deference more salient to outsiders. Avoiding lead plaintiff positions allows index fund managers to avoid both frictions and undesirable perceptions.

In response to our analysis it could be argued that it is not surprising that index fund managers avoid service as lead plaintiffs because they would not consider serving as a lead plaintiff to be economically worthwhile. ${ }^{221}$

the Big Three. See id. (noting also that "the most common plaintiffs in opt-outs are pension funds. Pension funds were present in 21 out of these 43 opt-out cases during 1996 to 2014."). Furthermore, the few cases of opt-outs do not explain why none of the Big Three took any lead plaintiff positions in the very large number of cases in which such opt-outs did not take place. In those cases, becoming the lead plaintiff would have enabled an index fund manager to lead the litigation while having their litigation costs shared with the rest of the securities class.

217. See supra section I.C.

218. See supra section I.C. For a related discussion of why large investment managers do not become lead plaintiffs, see David H. Webber, Private Policing of Mergers and Acquisitions: An Empirical Assessment of Institutional Lead Plaintiffs in Transactional Class and Derivative Actions, 38 Del. J. Corp. L. 907, 920-33 (2013); David H. Webber, Shareholder Litigation Without Class Actions, 57 Ariz. L. Rev. 201, 217-23 (2015).

219. See supra section I.D.

220. See supra section I.E.

221. For articles expressing such a view, see, for example, Platt, supra note 214 (manuscript at 41 n.209) (citing James D. Cox \& Randall S. Thomas, Does the Plaintiff Matter? An Empirical Analysis of Lead Plaintiffs in Securities Class Actions, 106 Colum. L. Rev. 1587, 1602-10 (2006)); Charles Silver \& Sam Dinkin, Incentivizing Institutional Investors to Serve as Lead Plaintiffs in Securities Fraud Class Actions, 57 DePaUl L. REv. 471, 472 (2008). A similar point was raised by Stephen Fraidin, a discussant of this Working Paper at the 2019 NYU Roundtable on Corporate Governance. 
However, this is exactly our point: Avoiding such positions is indeed consistent with the cost-benefit analysis of the index fund manager from their private economic perspective, even when taking such a position would serve the interests of the index fund's beneficial investors. It is for this reason that the avoidance of lead plaintiff positions, like the other patterns documented in this Part, is consistent with the agency-costs view of index fund stewardship.

\section{POLICY}

Our analysis in Part I has identified the incentives of index fund managers to underinvest in stewardship and to defer to corporate managers, and Part II has shown empirical evidence consistent with the significant influence of these incentives. In this Part we turn to the implications of our analysis for ongoing debates in the field of corporate governance. The nonNBER version of this Working Paper includes a detailed discussion of measures for addressing the incentive issues of index fund managers.

In section III.A we consider the significant implications that our analysis holds for two important ongoing debates in the corporate law field. We discuss the heated debates on common ownership (section III.A.1) and on hedge fund activism (section III.A.2). In both cases, we explain how our analysis undermines claims made in these debates, introduces new issues into the debates, and calls for revision of positions taken in the debates.

In section III.B, we comment on a more direct avenue through which our analysis could impact stewardship. We argue that, because index fund managers care about how their stewardship is viewed and wish to be perceived as good stewards, this is an area in which the mere recognition by the public of the incentives we identify might have an effect on index fund manager behavior. In particular, public recognition of the issues we analyze can induce index fund managers to make changes that would limit the effects of those incentives.

\section{A. Implications for Key Debates}

\section{The Debate on Common Ownership}

A significant body of recent academic work has expressed serious questions about one of the consequences of the rise of index funds: increases in common ownership, whereby an investment manager holds positions in all 
the companies in a given sector of the economy. ${ }^{222}$ These authors argue that a rise in common ownership, whether from index funds or otherwise, can be expected to produce significant anticompetitive effects that are detrimental to the economy. ${ }^{223}$ This view has led prominent legal scholars and economistsincluding Einer Elhauge, Herbert Hovenkamp, Eric Posner, Fiona Scott Morton, and Glen Weyl - to propose strong measures to constrain the rise of common ownership. Such measures include limiting investment managers to holding only one company in each economic sector, and having antitrust regulators scrutinize the behavior of index funds and other similar investors. ${ }^{224}$

The reform proposals put forward by the common ownership critics were significantly motivated by, and have substantially relied on, recent empirical work that claimed to find evidence that increases in common ownership bring about anticompetitive effects and, in particular, higher market prices. ${ }^{225}$ However, other economic and empirical analyses have contested the findings and conclusions of this empirical work and argued that it does not provide a solid empirical basis for the questions of the common ownership critics. ${ }^{226}$

222. For comprehensive reviews of this literature, see Matthew Backus, Christopher Conlon \& Michael Sinkinson, The Common Ownership Hypothesis: Theory and Evidence 18-24 (2019) [hereinafter Backus et al., The Common Ownership Hypothesis], https://www.brookings.edu/wp-content/uploads/2019/02/ES_20190205_Common-

Ownership.pdf [https://perma.cc/T5JP-SAGU]; Martin C. Schmalz, Common-Ownership Concentration and Corporate Conduct, 10 Ann. Rev. Fin. Econ. 413, 419-40, https://ssrn.com/abstract=3046829 (on file with the Columbia Law Review).

223. For a review of the common ownership literature from the perspective that argues that common ownership is likely to have a significant effect on the economy, see Schmalz, supra note 222, at 417 ("Shareholder diversification across competitors can therefore remove firms' incentives to compete and void Adam Smith's idea that the pursuit of shareholders' self-interest leads to maximization of social welfare.").

224. For articles suggesting such policy measures, see generally Einer Elhauge, Horizontal Shareholding, 129 Harv. L. Rev. 1267 (2016); Fiona Scott Morton \& Herbert Hovenkamp, Horizontal Shareholding and Antitrust Policy, 127 Yale L.J. 2026 (2018); Eric A. Posner, Fiona Scott Morton \& E. Glen Weyl, A Proposal to Limit the Anti-Competitive Power of Institutional Investors, 81 Antitrust L.J. 669 (2017).

225. For an influential empirical study on the airline industry that has received a great deal of attention, see generally José Azar, Martin C. Schmalz \& Isabel Tecu, Anticompetitive Effects of Common Ownership, 73 J. FIN. 1513 (2018). For another empirical study reporting similar findings with respect to the banking industry, see José Azar, Sahil Raina \& Martin C. Schmalz, Ultimate Ownership and Bank Competition (May 4, 2019) (unpublished manuscript), https://ssrn.com/abstract=2710252 (on file with the Columbia Law Review).

226. See, e.g., Backus et al., The Common Ownership Hypothesis, supra note 222; Daniel P. O'Brien \& Keith Waehrer, The Competitive Effects of Common Ownership: We Know Less than We Think, 81 Antitrust L.J. 729 (2017); Matthew Backus, Christopher Conlon \& Michael Sinkinson, Common Ownership in America: 1980-2017 (Nat'l Bureau

of Econ. Research, Working Paper No. 25454, 2019), 
Putting aside the debate on whether the hypothesis of the common ownership critics is consistent with the available empirical evidence, an important question is whether, on a conceptual level, it is reasonable to expect that an increase in common ownership in general, and such an increase due to a rise of index fund ownership in particular, should be expected to bring about anticompetitive effects. Our analysis questions the plausibility of this key theory. ${ }^{227}$

We agree that, in a hypothetical world without any agency issues between index fund managers and their beneficial investors, a rise in common ownership produced by the growth of index fund investing could have anticompetitive effects. Suppose, hypothetically, that the Big Three could be expected to make stewardship decisions as if they each had a sole owner acting to maximize the value of its portfolio. In this hypothetical scenario, it would be reasonable to question whether three large sole owners with large stakes in all significant public companies would have incentives to encourage anticompetitive effects. But as Parts I and II have shown, the world we inhabit is very far from such a hypothetical scenario.

In our world, the real worry is not that index funds might do too much, but that they might do too little. ${ }^{228}$ This Working Paper identifies significant incentives of index fund managers, which common ownership critics do not take into account. In particular, as Parts I and II have shown, index fund managers have insufficient incentives to engage in stewardship aimed at enhancing the value of particular companies, and they have significant incentives to defer to the preferences of corporate managers. Thus, contrary to the questions of common ownership critics, index fund managers are unlikely to push corporate managers to engage in business strategies that

https://www.nber.org/papers/w25454.pdf (on file with the Columbia Law Review); Jacob Gramlich \& Serafin Grundl, The Effect of Common Ownership on Profits: Evidence from the U.S. Banking Industry (Fed. Reserve Bd., Fin. \& Econ. Discussion Series Working Paper No. 2018-069, 2018), https://ssrn.com/abstract=3269120 (on file with the Columbia Law Review); Jacob Gramlich \& Serafin Grundl, Estimating the Competitive Effects of Common Ownership (Fed. Reserve Bd., Fin. \& Econ. Discussion Series Working Paper No. 2017-029, 2017), https://ssrn.com/abstract=2940137 (on file with the Columbia Law Review); Pauline Kennedy, Daniel P. O’Brien, Minjae Song \& Keith Waehrer, The Competitive Effects of Common Ownership: Economic Foundations and Empirical Evidence (July 24, 2017) (unpublished manuscript), https://ssrn.com/abstract=3008331 (on file with the Columbia Law Review).

227. For an in-depth response to our analysis as it relates to the debate on common ownership, see Elhauge, The Causal Mechanisms of Horizontal Shareholding, supra note 18 (manuscript at 39-58).

228. For a somewhat more detailed discussion of our view on this subject than in the current section, see Bebchuk \& Hirst, Misguided Attack on Common Ownership, supra note 18. 
those corporate managers would not wish to pursue on their own.

Indeed, we believe that the alarmism over common ownership, and the scrutiny that such alarmism brings, may have two counterproductive consequences. First, such alarmism may push index fund managers to act even more deferentially than they have to date. Thus, by strengthening deference incentives, such alarmism could move stewardship further away from, rather than toward, the value-maximizing benchmark.

Furthermore, common ownership alarmism might push antitrust regulators in the wrong direction. There is evidence that concentration in many markets and the associated increases in markups have been on the rise in recent decades. ${ }^{22}$ Dealing with such concentration requires antitrust regulators to focus their attention on the decisions of corporate managers. The common ownership issue may distract antitrust regulators by unnecessarily focusing their attention on ownership patterns and the stewardship of index fund managers.

\section{The Debate on Hedge Fund Activism}

The past decade has witnessed a heated debate over the merits of hedge fund activism and how it should be governed. ${ }^{230}$ Supporters of hedge fund activism contend that it brings about value-enhancing changes in activism targets, and that it exerts a disciplinary force that induces incumbents to be more attentive to shareholder interests. ${ }^{231}$ Opponents of hedge fund activism claim that it pushes public companies to improve short-term outcomes at the expense of long-term value, which is detrimental to investors in those companies, as well as to the economy. ${ }^{232}$ This has led these opponents to

229. For a study providing empirical evidence on the rise in market concentration, see Gustavo Grullon, Yelena Larkin \& Roni Michaely, Are US Industries Becoming More Concentrated?, 23 Rev. Fin. 697, 698 (2019) (reporting evidence that, "over the last two decades the Herfindahl-Hirschmann index [a measure of market concentration] has systematically increased in more than $75 \%$ of US industries").

230. For articles putting forward policy arguments for and against hedge fund activism, see, respectively, Bebchuk et al., Hedge Fund Activism, supra note 173, at 1147-54, and Leo E. Strine, Jr., Who Bleeds When the Wolves Bite: A Flesh-and-Blood Perspective on Hedge Fund Activism and Our Strange Corporate Governance System, 126 Yale L.J. 1870, 195670 (2017) [hereinafter Strine, Who Bleeds].

231. For works that provide a favorable assessment of hedge fund activism, see generally Bebchuk \& Jackson, supra note 89; Alon Brav, Wei Jiang \& Hyunseob Kim, Hedge Fund Activism: A Review, 4 Found. \& Trends Fin. 185 (2009).

232. For works that analyze potential costs of hedge fund activism in detail, see, for example, John C. Coffee, Jr. \& Darius Palia, The Wolf at the Door: The Impact of Hedge Fund Activism on Corporate Governance, 1 ANNALS CORP. GOVERNANCE (2016); Strine, Who Bleeds, supra note 230; Martin Lipton, The Threat to the Economy and Society from Activism and Short-Termism, Harvard Law Sch. Forum on Corp. Governance \& Fin. 
advocate for various measures to constrain activist hedge funds. ${ }^{233}$

Our analysis has significant implications for this ongoing debate. We make two main points in this regard. In section III.A.2(a) we explain that the rise of index funds in general, and the Big Three in particular, cannot substitute for the important role that activist hedge funds play in the corporate governance system. In section III.A.2(b) we show that although activist hedge funds play a useful role, their presence cannot fully make up for the significant issues that we identify with index fund stewardship, since these issues mean that the combination of index funds and activist hedge funds cannot fully address common corporate governance issues.

(a) The Limits of Index Fund Stewardship. Given the long-term focus of index funds, opponents of hedge fund activism view index fund stewardship as a preferable substitute for the activities of activist hedge funds, and have urged index fund managers to support companies against activist hedge funds. $^{234}$ However, the analysis in this Working Paper suggests that understanding the stewardship incentives and behavior of index fund managers should lead to support for hedge fund activism rather than opposition. The issues with index fund stewardship that we identify mean that index fund stewardship cannot be a substitute for hedge fund activism. To the contrary, these issues imply that hedge fund activism has a critical role in stewardship.

The incentives of hedge fund managers differ from those of the index fund managers that we have analyzed in three key ways. ${ }^{235}$ First, whereas index fund managers capture a tiny fraction of the governance gains that they produce, the so-called "2-and-20" compensation arrangements of hedge fund managers enable them to capture a meaningful proportion of any governance gains they bring about. Second, index fund managers hold the same portfolios as rival managers tracking the same indexes and thus cannot improve

Regulation (Jan. 22, 2015), https:/corpgov.law.harvard.edu/2015/01/22/the-threat-to-theeconomy-and-society-from-activism-and-short-termism [https://perma.cc/ZD6X-R7ZZ].

233. For a review of such measures proposed by opponents of hedge fund activism, see Bebchuk et al., Hedge Fund Activism, supra note 173, at 1147-54.

234. For example, Martin Lipton, a well-known opponent of hedge fund activism, has stated that "[BlackRock CEO Larry Fink's 2018 Letter to CEOs] is a major step in rejecting activism and short-termism," Lipton, New Paradigm for Corporate Governance, supra note 13, and that "BlackRock, State Street and Vanguard have continued to express support for sustainable long-term investment," Lipton, State of Play, supra note 42. For a review of the opposition to hedge fund activism coauthored by one of us, see Bebchuk et al., Hedge Fund Activism, supra note 173, at 1093-96.

235. For a more detailed analysis of why agency issues afflict the stewardship decisions of activist hedge funds to a lesser extent than they do for the stewardship decisions of index funds and other mutual funds, see Bebchuk et al., Agency Problems of Institutional Investors, supra note 15 , at $104-06$. 
performance relative to rivals by bringing about governance gains. In contrast, activist hedge funds have concentrated portfolios, and governance gains in their main portfolio companies can thus greatly enhance their performance relative to rivals. Third, hedge fund managers generally do not have other business relationships with their portfolio companies, so they lack the other types of incentives that we have identified as inducing index fund managers to be excessively deferential to corporate managers.

These different incentives cause hedge fund managers to invest substantial amounts in the stewardship of their portfolio companies. ${ }^{236}$ Hedge fund managers closely follow the particular business circumstances of those companies and identify ways to remedy underperformance. They can also use the full toolkit of shareholder powers - including nominating directors - visà-vis companies that they identify as underperforming.

Given these substantial differences in incentives and consequent stewardship behavior, index fund stewardship cannot substitute for hedge fund activism, and especially not with respect to remedying the underperformance of portfolio companies. The work of activist hedge funds in targeting and remedying underperformance can partially address the substantial gap left by the lack of stewardship by index fund managers, and thereby benefit index fund investors. Conversely, opposition to hedge fund activism would be contrary to the interests of index fund investors.

(b) The Limits of Hedge Fund Activism. In a well-known and influential article, Ronald Gilson and Jeffrey Gordon express a more optimistic view on this subject and argue that the current interaction of index funds and activist hedge funds works very well to address corporate governance issues at portfolio companies. ${ }^{237}$ In the view of Gilson and Gordon, the actions of the two types of players complement each other well: Hedge funds identify target companies in which changes would enhance value, and index funds (and other mutual funds) provide the activist hedge funds with support in those cases where changes would be value-enhancing. Subsequently, commentators taking issue with our work have also taken the view that the interaction between activist hedge funds and index funds works well and enables issues of underperformance to be effectively addressed. ${ }^{238}$ The assistance of these investment managers thus enables hedge fund activists to bring about these value-enhancing changes.

Below we explain that, although hedge fund activism can partially

236. Id.

237. Gilson \& Gordon, supra note 17 , at 897-900.

238. For articles by such commentators, see, for example, Fisch et al., supra note 16 (manuscript at 19) ("Passive funds also play a complementary role in the more focused engagement provided by hedge funds"); Jahnke, supra note 59, at 3 ("[I]nterviews with activist investors suggest that index investors do not pose barriers to successful campaigns."). 
address the issues with index fund stewardship that we analyze, such activism cannot fully address them. In particular, the current interaction of activist hedge funds and index funds cannot fully address corporate governance issues as Gilson and Gordon, and commentators taking issue with our view of index fund stewardship, appear to hope. There are three reasons for this.

First, an activist hedge fund can be successful at a company only if that company's management expects index fund managers to support the activist hedge fund. ${ }^{239}$ However, as we have explained in the preceding Part, index fund managers have incentives to be excessively deferential to corporate managers. The recent study by Alon Brav, Wei Jiang, Tao Li, and James Pinnington provides empirical evidence that index funds are indeed less likely than other institutional investors to support activists in contested elections. $^{240}$ To the extent that index fund managers are expected not to support some value-enhancing changes that activist hedge funds would like to bring about, activist hedge funds would likely be unable to bring about such changes themselves. ${ }^{241}$

239. For discussions of the need for hedge fund activists to obtain the support of investment managers in order to be successful, see Bebchuk \& Jackson, supra note 89, at 5253; Gilson \& Gordon, supra note 17, at 897-900.

We note that activist hedge funds may engage with companies not only to change the ongoing strategy of the company but also to resist proposals to acquire a company that would not serve the interests of the company's shareholders. For reasons similar to those discussed above, the ability of activist hedge funds to prevent such transactions would depend on the quality of stewardship by index funds. For a discussion of the importance of institutional investors in votes to approve going private transactions, see Amir Licht, Farewell to Fairness: Towards Retiring Delaware's Entire Fairness Review (European Corp. Governance Inst., Finance Working Paper No. 557/2018, 2019), https://ssrn.com/abstract=3119935 (on file with the Columbia Law Review).

240. See Brav et al., Picking Friends, supra note 166.

241. In taking the view that activists and index funds interact well, Fisch, Hamdani, and Davidoff Solomon rely on an empirical study by Ian Appel, Todd Gormley, and Donald Keim on the effect of passive investors on activism. See Fisch et al., supra note 16 (manuscript at 28) (citing Ian R. Appel, Todd A. Gormley \& Donald B. Keim, Standing on the Shoulders of Giants: The Effect of Passive Investors on Activism, 32 Rev. Fin. Stud. 2720 (2019) [hereinafter Appel et al., Shoulders of Giants]). Appel et al.'s study reports that "the percentage of a firm's stock held by passive mutual funds is not associated with the likelihood of being targeted by an activist," but that "passive mutual funds significantly affect activists' strategic choices," and in particular "the presence of passive institutions increases activists" willingness to engage in costlier forms of activism." Appel et al., Shoulders of Giants, supra, at 2723 .

However, Fisch et al. do not engage with the findings that "a larger ownership stake by passive funds is associated with a decline in hedge fund activism," made by the same authors in an earlier study. Appel et al., Passive Investors, Not Passive Owners, supra note 149, at 114; see also Fisch et al., supra note 16. Moreover, and importantly, Fisch et al. do not cite or engage with the subsequent and comprehensive study on the subject by Brav et al., which 
Second, not only do activist hedge funds require the support of index funds to succeed in engagements that they undertake, but the expectation of a lack of index fund support might have a counterproductive ex ante effect: It could discourage hedge fund activists from engaging with companies in the first place. Consistent with this observation, the recent study by Alon Brav and coauthors shows that activist hedge funds are less likely to engage underperforming companies when the investors in those company have been less supportive of activist hedge funds nominees in past votes. ${ }^{242}$

Third, activist hedge funds have incentives to undertake stewardship activities only when such activities could result in very large increases in value. Activist hedge funds invest substantial resources in stewardship and take on considerable risks in their activities, including liquidity risks and risks of unsuccessful engagements. To compensate, activist hedge funds' own beneficial investors demand higher returns, which must sustain first paying the substantial 2-and-20 fees charged by the hedge fund manager. As a result, activist hedge fund managers will take on engagements only where they would likely bring about large returns, sufficient to compensate their investors on a risk-adjusted basis after the managers' high fees. There will be many opportunities for smaller gains from stewardship-say, of approximately $5 \%$ to $10 \%$ - that activist hedge funds will ignore but that would significantly benefit index fund investors if they were realized.

For these three reasons, activist hedge funds can be only a limited substitute for the lack of stewardship by index fund managers. Consequently, the issues with index fund stewardship identified in this Working Paper will remain of substantial importance-even if activist hedge funds are allowed to continue to operate without the impediments sought by their opponents.

\section{B. Recognition and Reality}

Before we conclude this Part we wish to note that this is an area in which improved understanding of issues can also directly contribute to their solution. ${ }^{243}$ Thus, improving the understanding of current issues could by

shows that, after controlling for relevant characteristics, index funds are significantly and systematically less likely to vote with activists, and that the expectation of such voting behavior affects activists' choices of companies to target. See Brav et al., supra note 166; Fisch et al., supra note 16.

242. See Brav et al., Picking Friends, supra note 166 at 24-25. The findings of Brav et al. are consistent with those reported by an earlier study by Appel et al., Passive Investors, Not Passive Owners, supra note 149, at 114.

243. For a discussion of another context in which recognition of existing issues by investors and the public can substantially contribute to improving matters, and where academic work highlighting such issues can usefully contribute to such recognition and 
itself contribute to improving index fund stewardship.

As we explained in section I.F, the Big Three have significant incentives to be perceived as responsible stewards. A public perception that they are otherwise might decrease their fund inflows or increase the risks of backlash. The Big Three thus have reasons to communicate in ways that portray their stewardship in a favorable light, and to make stewardship decisions that reduce the salience of their underinvestment in stewardship and their excessive deference to corporate managers. Therefore, recognition by investors and the public of the incentive issues of index fund managers could, by itself, lead to improved stewardship by the Big Three. In particular, recognition of the extent of the Big Three incentives to underinvest in stewardship might partially counteract their incentives to underinvest. Similarly, recognition of the extent of the deference incentives of index fund managers might constrain such deference.

To illustrate, the evidence that we have provided regarding the scale of the Big Three's investments in stewardship could contribute to public pressure on the Big Three to increase their investments in stewardship. Discussions of Big Three stewardship levels by Big Three leaders and supporters of index fund stewardship have thus far paid close attention to the significant increases in personnel in the Big Three's stewardship departments in recent years and the significant number of people currently employed in these departments. ${ }^{244}$ However, evidence that we describe in Part II shows that, notwithstanding increases in personnel in recent years, the Big Three's investments in stewardship currently enable them to devote limited resources to stewardship in the great majority of the companies in which they hold positions of significant monetary value. Introducing this point could be salient for public discussions.

To take another example, the evidence we describe in section II.B regarding the Big Three's choice not to use certain potentially-valuable stewardship tools could increase investor and public pressure on the Big Three to use those tools. In particular, our analysis in section II.B. 3 showed that the Big Three have generally avoided any submission of shareholder proposals of the type that they generally support and that could bring about governance changes that the Big Three's own governance principles consider valuable. Public recognition of these findings could contribute to investor and public pressure on the Big Three to consider active submission of shareholder proposals to bring about these governance reforms. Similarly, our analysis in section II.B.4 shows that the Big Three have commonly chosen to remain on

improvement, see Lucian A. Bebchuk \& Jesse M. Fried, Pay Without Performance: The Unfulfilled Promise of Executive Compensation 201-16 (2004) (explaining that recognition of the issues with executive pay arrangements can by itself improve matters).

244. For such comments, see supra notes 10, 11, 121-124 and accompanying text. 
the sidelines in cases of SEC consideration of proposed rules and precedential litigation; these findings could thus lead to investor and public pressure on the Big Three to increase their involvement in such activities.

This is therefore an area in which recognition of incentive issues might by itself contribute to improving matters. We therefore hope that this Working Paper, and the analysis and empirical evidence that we provide, will contribute to investor and public recognition of the issues that we have examined.

\section{CONCLUSION}

With index funds owning a large and steadily-increasing proportion of the equity capital of all significant American public companies, understanding the stewardship decisions of index fund managers - and how they can be improved - is of critical importance for all interested in the governance and performance of public companies. In this Working Paper we have sought to contribute to this understanding.

This Working Paper has put forward an analytical framework for understanding the incentives of index fund managers. Our framework has enabled us to identify and analyze two types of incentives that could well affect the stewardship decisions of index fund managers: incentives to underinvest in stewardship, and incentives to defer excessively to the preferences and views of corporate managers.

This Working Paper has also provided a comprehensive empirical analysis of the full range of stewardship activities that index fund managers do and do not undertake. We have explained that the empirical evidence is, on the whole, consistent with the predictions of our incentive analysis. The empirical evidence thus reinforces the questions raised by our analysis.

Finally, this Working Paper has considered the significant implications of the incentives issues that we identify analytically and document empirically. We show that our analysis undermines the arguments that critics have made against common ownership by institutional investors and activism by hedge funds, thereby contributing to these important policy debates.

We hope that the analytical framework, evidence, and discussion of implications that we have provided may prove useful for students of this topic and market participants in considering the opportunities and challenges posed by the rise of index funds. The responses to these opportunities and challenges will have profound effects on the governance and performance of public companies and, in turn, on the prosperity of investors and the success of the American economy. 


\section{APPENDIX: DATA SOURCES}

This Appendix describes the sources of data used in the empirical analyses in the various sections of Part II of this Working Paper.

\section{A. What the Big Three Do, and How They Do It}

\section{Stewardships Budgets and Personnel}

For the empirical analyses in section II.A.1, including the results reported in Tables 1-3, we used the most recent data that we were able to obtain for each of the Big Three relating to (a) level of personnel, (b) total number of portfolio companies, (c) number of U.S. portfolio companies, (d) total equity assets under management, (e) equity under management invested in U.S. portfolio companies, and (f) fees and expenses.

(a) Level of Personnel. Data on the number of stewardship personnel for BlackRock were obtained from the most recent annual stewardship report; for SSGA, from a recent article in the Wall Street Journal; and for Vanguard, from a Morningstar report by Bioy and coauthors. ${ }^{245}$

(b) Total Number of Portfolio Companies. Data on the total number of portfolio companies for Vanguard are from its annual stewardship report. ${ }^{246}$ BlackRock and SSGA do not disclose the total number of their portfolio companies. We estimate those figures as the number of company meetings at which BlackRock and SSGA voted, multiplied by the ratio of the number of meetings at which Vanguard voted to the number of Vanguard's portfolio companies.

(c) Number of U.S. Portfolio Companies. Data on the number of U.S. portfolio companies for each of the Big Three are from the FactSet Ownership database. ${ }^{247}$ Because this data include securities held in other investment funds we exclude positions in securities with a Standard Industrial Classification (SIC) industry code of "672 Investment Offices," which

245. See BlackRock, BlackRock, 2019 Investment Stewardship Annual Report (2019), https://www.blackrock.com/corporate/literature/publication/blk-annual-stewardship-report2019.pdf [https://perma.cc/9C4S-EBWU] [hereinafter BlackRock, Annual Stewardship Report 2018-19]; State St. Glob. Advisors, Annual Stewardship Report 2018, supra note 51, at 9; Vanguard, Annual Stewardship Report 2018-19, supra note 155; Dawn Lim, Index Funds Are the New Kings of Wall Street, Wall St. J. (Sept. 18, 2019), https://www.wsj.com/articles/index-funds-are-the-new-kings-of-wall-street-11568799004 (on file with the Columbia Law Review); Bioy et al., supra note 50, at 19 exh.10.

246. Vanguard, Annual Stewardship Report 2018-19, supra note 155.

247. See BlackRock, Annual Stewardship Report 2018-19, supra note 245; FactSet Res. Sys., Ownership Database (last visited Oct. 3, 2019). 
includes two industry sectors, "6722 Management Investment Offices, OpenEnd," and "6726 Unit Investment Trusts, Face-Amount Certificate Offices, and Closed-End Management Investment Offices."

(d) Total Equity Assets Under Management. Data on total equity assets under management for BlackRock and SSGA are from their most recent annual reports on Form 10-K, and, for Vanguard, from its annual stewardship report. $^{248}$

(e) Equity Under Management Invested in U.S. Portfolio Companies. Data on the equity assets under management in U.S. companies are from FactSet Ownership. ${ }^{249}$

(f) Fees and Expenses. Fees and expenses for each of the Big Three are estimated by multiplying total equity assets under management by the average expense ratios for each of the Big Three. Average expense ratios are from Morningstar. ${ }^{250}$

\section{Private Engagements}

The analyses in section II.A.2, including the results reported in Table 4, are based on data from the Big Three Stewardship Reports. We use this data to obtain or estimate, for each of the Big Three, in each year from 2017 to 2019, (i) how many portfolio companies they had, (ii) how many of those companies they engage with, and (iii) how many of those companies had more than one engagement. For (i) we use the data for the number of portfolio companies used in section II.A. 1 and Table 1 and described in supra note 126. Below we explain how we derive (ii) and (iii) for each of the Big Three.

(a) SSGA. SSGA provides information regarding the number of companies with which it engaged and the number of companies with which it had multiple engagements for each year from 2017 to 2019 in its Annual Stewardship Reports. ${ }^{251}$

(b) BlackRock. BlackRock's 2019 Annual Stewardship Report provides data on the number of companies with which it engaged, and the proportion

248. BlackRock, Annual Report for the Year Ended December 31, 2018 (Form 10-K), at 2 (Feb. 28, 2019); State St. Corp., Annual Report for the Year Ended December 31, 2018 (Form 10-K), at 71 (Feb. 21, 2019); Vanguard, Investment Stewardship: 2019 Annual Report 9, 29 (2019).

249. FactSet Res. Sys., Ownership Database (last visited Oct. 3, 2019).

250. Morningstar, supra note 58, at 12.

251. See State St. Glob. Advisors, Annual Stewardship Report 2016, supra note 9, at 5; State St. Glob. Advisors, Stewardship 2017, at 6-7 (2018), https://www.ssga.com/investment-topics/environmental-social-governance/2018/07/annualstewardship-report-2017.pdf [https://perma.cc/VY47-TF8R] [hereinafter, State St. Glob. Advisors, Annual Stewardship Report 2017]; State St. Glob. Advisors, Annual Stewardship Report 2018, supra note 51, at 13-14. 
of those companies with which it had multiple engagements. ${ }^{252}$ But in prior years that data is not available. In 2018, BlackRock disclosed the number of companies with which it engaged, but not the number of companies with which it had multiple engagements. ${ }^{253}$ We infer that number by assuming, conservatively, that BlackRock conducted no more than two engagements with any portfolio company. This allows us to deduce the maximum number of companies with which BlackRock held multiple engagements. ${ }^{254}$ In 2017 BlackRock disclosed the total number of its engagements, but not the number of companies it engaged with or the number of companies that had multiple engagements. ${ }^{255}$ We estimate the number of companies engaged and the number of multiple engagements by assuming that the proportion of companies that BlackRock engaged with in 2017 that involved multiple engagements was the same as for 2018.

(c) Vanguard. Vanguard's 2017 Annual Stewardship Report disclosed the number of its engagements and the number of companies with which it held engagements in that year. ${ }^{256}$ We use that data to infer the maximum number of multiple engagements in the same way as for BlackRock. Vanguard did not disclose its total number of engagements for 2018 or $2019 .{ }^{257} \mathrm{We}$ therefore estimate the proportion of its portfolio with which it held multiple engagements by assuming that the proportion of the companies it engaged with that involved multiple engagements was the same in 2018 and 2019 as it was in 2017.

\section{Focusing on Divergences from Governance Principles}

The analyses in section II.A.3 are based on a review of the Big Three Stewardship Reports and the proxy voting guidelines of each of the Big

252. See BlackRock, Annual Stewardship Report 2018-19, supra note 245, at 4.

253. See BlackRock, BlackRock Investment Stewardship 2018 Annual Report 20 (2018) https://www.blackrock.com/corporate/literature/publication/blk-annual-stewardship-report2018.pdf [https://perma.cc/VAK5-ZBGV] [hereinafter, BlackRock, Annual Stewardship Report 2017-18]

254. See BlackRock, Annual Stewardship Report 2018-19, supra note 245, at 4. This estimate is conservative because if BlackRock held more than two engagements with any companies then the number of companies with which it held multiple engagements would be fewer than we estimate. Indeed, our approach would result in an estimate of $40.6 \%$ of the companies it engaged with having multiple engagements, whereas by its own disclosure the actual proportion was $25 \%$.

255. See BlackRock, Annual Stewardship Report 2016-17, supra note 141, at 20.

256. See Vanguard, Annual Stewardship Report 2016-17, supra note 122, at 15.

257. See Vanguard, Annual Stewardship Report 2017-18, supra note 45, at 8; Vanguard, Annual Stewardship Report 2018-19, supra note 155, at 7. 
Three. $^{258}$

\section{Pro-Management Voting}

The analyses in section II.A.4, including the results reported in Tables 5 and 6, are based on voting data on say-on-pay proposals from ISS Voting Analytics. ${ }^{259}$ S\&P 500 constituency data is from Compustat. ${ }^{260}$ Equity holdings of investment managers is based on Form 13F data from FactSet Ownership. ${ }^{261}$

We consider a fund manager to have voted "no" on a company's say-onpay proposal if a plurality of their respective funds cast against votes on that proposal. Weighted averages of vote proportions from different funds are weighted by the total assets under management in U.S. equities. The largest active fund managers were determined based on their aggregate ownership positions for all U.S. equities. Abstentions and proposals for which no vote was recorded for a particular investment manager are excluded from the proportions presented, but due to the negligible incidence of abstentions and non-votes their inclusion would not have any qualitative effect on the results.

\section{B. What the Big Three Do Not Do}

\section{Monitoring Business Performance}

The analyses in section II.B.1 are based on a review of the Big Three Stewardship Reports and the Big Three Proxy Voting Guidelines.

\section{Influencing Director Identity}

The analyses in section II.B.2, including the results reported in Tables 7 and 8 , are based on data on director nominations from SharkRepellent.net, ${ }^{262}$ and Schedule 13D filings from the SEC's EDGAR database. ${ }^{263}$ S\&P 500

258. See BlackRock, BlackRock Investment Stewardship Global Corporate Governance

Guidelines \& Engagement Principles (Jan. 2019),
https://www.blackrock.com/corporate/literature/fact-sheet/blk-responsible-investmentengprinciples-global.pdf [https://perma.cc/Y53Q-WX73]; State St. Glob. Advisors, Proxy Voting and Engagement Guidelines 2019, supra note 110; Vanguard, Proxy Voting Guidelines, supra note 110, at 12.

259. Institutional Shareholder Services (last visited Oct. 3, 2019).

260. Compustat (last visited Oct. 3, 2019).

261. FactSet Res. Sys., Ownership Database (last visited Oct. 3, 2019).

262. SharkRepellent.net (last visited Sept. 26, 2019).

263. EDGAR Database, SEC (last visited Sept. 16, 2019). 
constituency data are from Compustat. ${ }^{264}$ Data regarding Big Three positions of $5 \%$ or more are based on institutional ownership data from FactSet Ownership. ${ }^{265}$ Data for BlackRock for 2010 onwards includes positions held by Barclays Global Investors, which BlackRock acquired in December 2009.

\section{Eliminating Divergences from Governance Principles}

The analyses in section II.B.3, including Table 9, are based on shareholder proposal data and governance arrangement data from SharkRepellent.net. ${ }^{266}$ Russell 3000 constituent data is also from SharkRepellent.net. ${ }^{267}$ We exclude social responsibility proposals, and proposals that are part of proxy contests. Proposals receiving majority support are those for which votes cast in favor represent a majority of the votes cast in favor, against, and in abstention.

\section{Contributing to Corporate Governance Legal Reforms}

(a) SEC Comment Letters. The analyses in section II.B.4(a), including Table 10, regarding SEC comment letters are based on a review of comment letters submitted for SEC proposed rules and which are listed on the SEC webpage for each proposed rule. ${ }^{268}$ When there were several requests for comment on a regulatory initiative we counted it as one proposed rule, so long as the SEC placed all of the comments in one common file. The total number of comments for asset owners are less than the sum of comments by CalPERS and CalSTRS as several comments were submitted jointly. The Big Three comments in Table 10 include two letters from subsidiaries of State Street Corporation that operate different businesses from SSGA.

(b) Amicus Curiae Briefs in Precedential Litigation. The analyses in section II.B.4(b) regarding amicus curiae briefs, including Table 11, are based on a review of the dockets and decisions for the cases listed in Table 11. For the Supreme Court decisions listed in Table 11, the amicus briefs considered include those submitted regarding petitions for certiorari.

264. Compustat (last visited Oct. 3, 2019).

265. FactSet Res. Sys., Ownership Database (last visited Oct. 3, 2019).

266. SharkRepellent.net (last visited June 10, 2019).

267. SharkRepellent.net (last visited June 10, 2019).

268. For SEC webpages of proposed rules, see Proposed Rules, SEC, https://www.sec.gov/rules/proposed.shtml [https://perma.cc/7UGK-LB5L] (last visited Sept. $8,2019)$. 


\section{Involvement in Securities Litigation}

The analyses in section II.B.5, including Table 12, are based on data from Institutional Shareholder Services' Securities Class Action Database. Cases involving multiple or partial settlements are included in the year in which the settlement was made but only if the aggregate settlement for that case has exceeded $\$ 10$ million or $\$ 100$ million, as appropriate. 